\title{
Water Resources and Potential Effects of Ground-Water Development in Maggie, Marys, and Susie Creek Basins, Elko and Eureka Counties, Nevada
}

By Russell W. Plume

U.S. GEOLOGICAL SURVEY

Water-Resources Investigations Report 94-4222

Prepared in cooperation with the

NEVADA DIVISION OF WATER RESOURCES

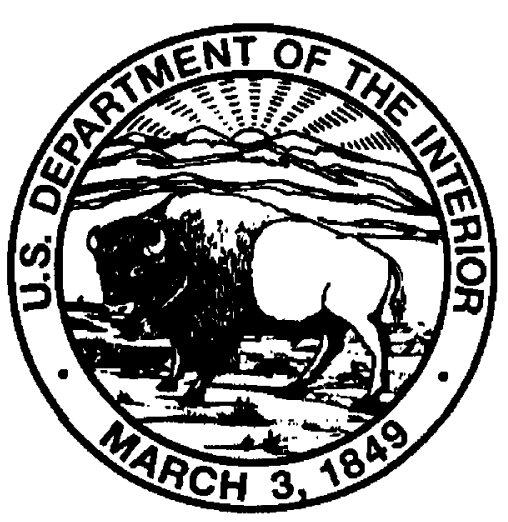

Carson City, Nevada 1995 


\title{
U.S. DEPARTMENT OF THE INTERIOR BRUCE BABBITT, Secretary
}

\author{
U.S. GEOLOGICAL SURVEY \\ GORDON P. EATON, Director
}

Any use of trade names in this publication is for descriptive purposes only and does not constitute endorsement by the U.S. Government.

For additional information write to:

U.S. Geological Survey 333 West Nye Lane, Room 203 Carson City, NV 89706-0866
Copies of this report can be purchased from:

U.S. Geological Survey

Information Services

Box 25286, MS 517

Denver Federal Center

Denver, CO 80225-0046 


\section{CONTENTS}

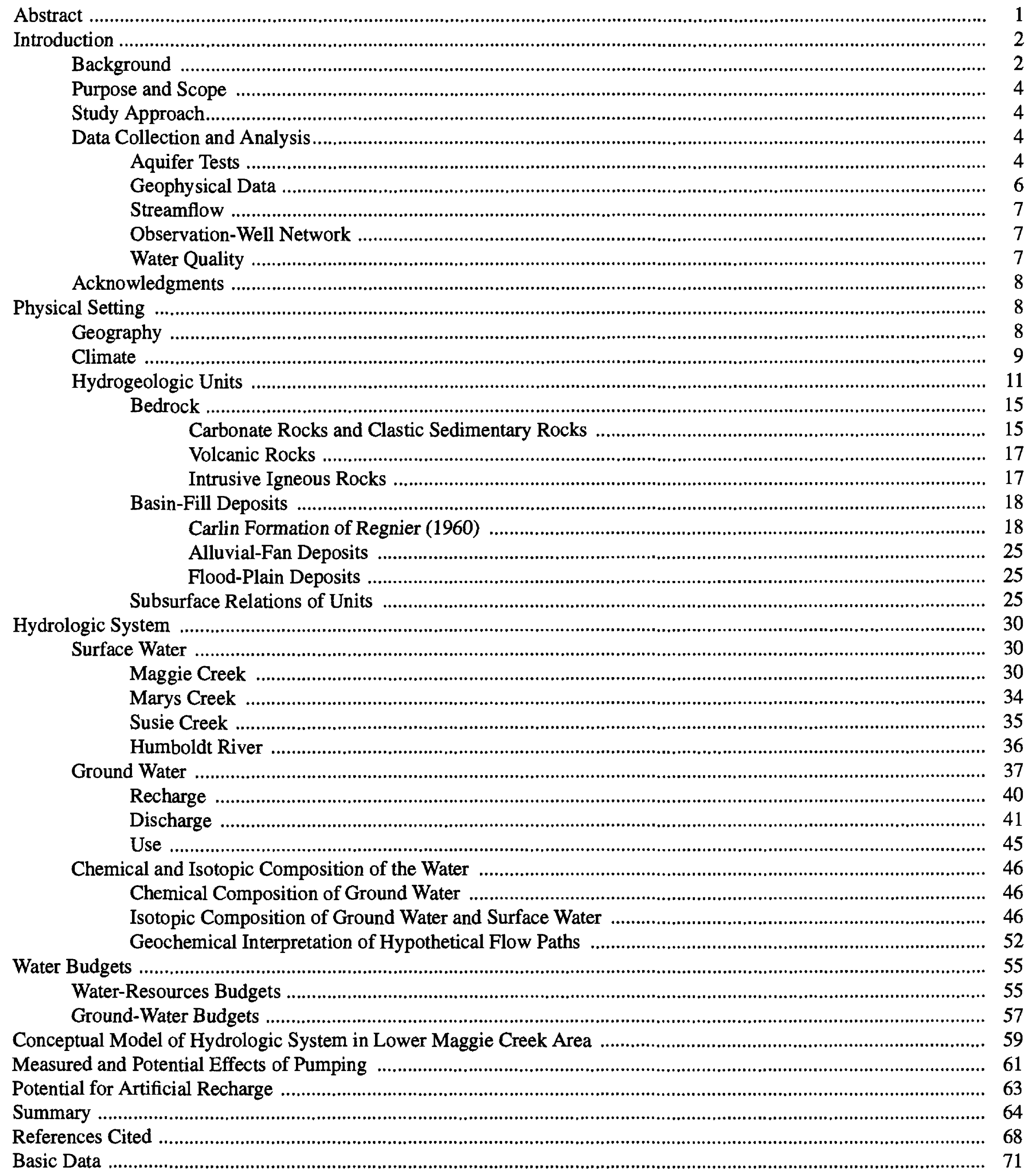




\section{Figures}

1-3. Maps showing:

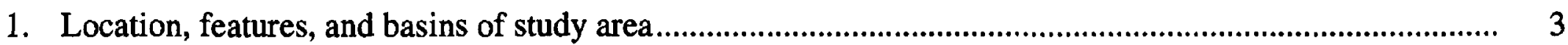

2. Features and basins of lower Maggie Creek area .................................................................................... 5

3. Locations of 14 weather stations in northeastern Nevada ................................................................... 10

4. Graphs showing relation of mean annual precipitation to station altitude and relation of difference between predicted and measured precipitation to predicted mean annual precipitation .................... 11

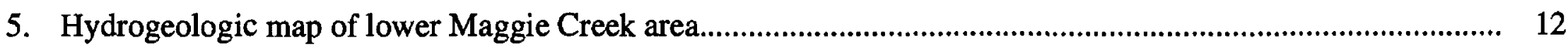

6-11. Graphs showing analyses of aquifer tests:

6. Water-level recovery at production well 52 after step-drawdown test...................................................... 16

7. Water-level drawdown at observation well 13 during constant-discharge test at

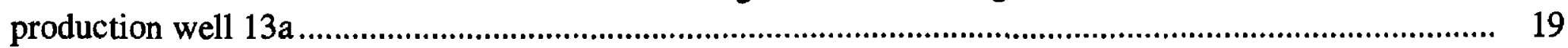

8. Water-level recovery at production well $13 \mathrm{a}$ after step-drawdown test .................................................... 20

9. Water-level drawdown at observation wells 13 and 14 during step-drawdown test at production well 13a

10. Step-drawdown test at production well 41 and observation wells 42 and $42 \mathrm{a}$; water-level recovery at well 41 and water-level drawdown at wells 42 and $42 \mathrm{a}$

11. Water-level recovery at well 43 after step-drawdown test

12-13. Maps of lower Maggie Creek area showing:

12. Complete Bouguer gravity field

13. Total-intensity magnetic field

14-15. Generalized geologic sections and corresponding profiles of complete Bouguer gravity anomaly and magnetic intensity:

14. Section $A-A^{\prime}$

15. Section $B-B^{\prime}$

16. Map showing locations of stream-gaging stations and miscellaneous streamflow-measurement sites in lower Maggie Creek area...

17-21. Graphs showing:

17. Frequency distribution of discharge of Maggie Creek near its mouth, water years 1914-24.

18. Flow characteristics of Maggie Creek at upper and lower gages, water years 1990-91

19. Daily mean discharge of Marys Creek at Carlin, water years 1990-91; and Susie Creek near Carlin, water years 1956-58

20. Daily mean discharge of Humboldt River near Carlin, water years 1982-91

21. Streamflow gains of Humboldt River between Carlin and Palisade gages, water years 1944-91

22-24 Maps showing:

22. Altitude of shallow ground-water levels in lower Maggie Creek area, September 1990

23. Distribution of phreatophytes and irrigated cropland in study area

24. Locations of wells, springs, and surface-water sites sampled for water quality in lower Maggie Creek area

25. Graph showing general chemical character of sampled ground water in lower Maggie Creek area

26. Map showing areal distribution of tritium and deuterium values for ground water and surface water in lower Maggie Creek area..

27. Graph showing relation between deuterium and oxygen-18 for ground-water and surface-water samples in lower Maggie Creek area.....

28. Conceptual hydrogeologic section $\mathbf{A}-\mathrm{A}^{\prime}$ in lower Maggie Creek area.

29. Map showing wells in lower Maggie Creek area where water-level changes were measured, March 1989-September 1990 


\section{Tables}

1. Altitude, mean annual precipitation, and period of record for 14 weather stations in northeastern Nevada......... 10

2. Summary of hydrogeologic units and their properties in lower Maggie Creek area, northeastern Nevada .......... 14

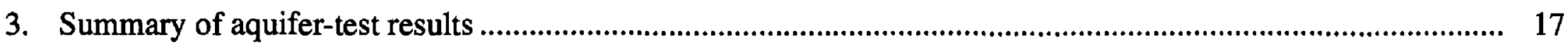

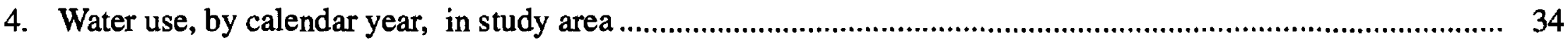

5. Estimated potential ground-water recharge from precipitation in study area ................................................. 41

6. Estimated long-term ground-water discharge in study area.................................................................... 44

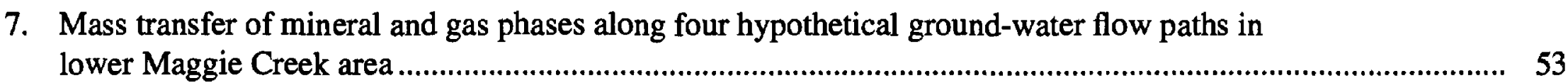

8. Saturation indices for mineral phases in ground water at ends of four hypothetical flow paths in

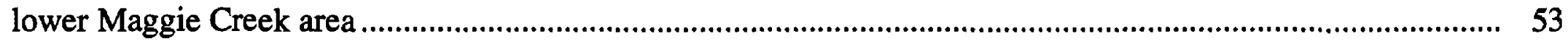

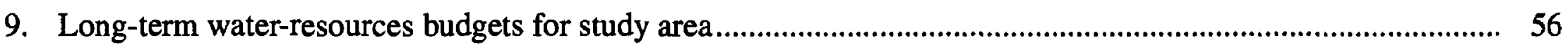

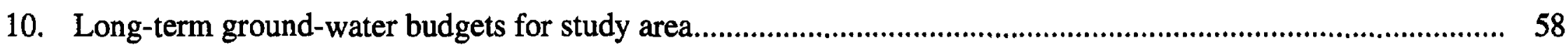

11. Streamflow and other data for surface-water sites in lower Maggie Creek area .............................................. 72

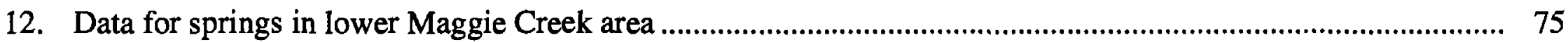

13. Water levels and data for wells in lower Maggie Creek area............................................................... 76

14. Water-quality data used for geochemical modeling of ground-water flow paths in lower Maggie Creek area..... 86

\section{CONVERSION FACTORS, TEMPERATURE, VERTICAL DATUM, AND ABBREVIATIONS OF METRIC WATER-QUALITY AND GEOPHYSICAL UNITS}

\begin{tabular}{rll}
\hline Multiply & By & To obtain \\
acre & 0.4047 & square hectometer \\
acre-foot $(\mathrm{acre}-\mathrm{ft})$ & 0.001233 & cubic hectometer \\
cubic meter per year \\
acre-foot per year $(\mathrm{acre}-\mathrm{ft} / \mathrm{yr})$ & 1,233 & liter per second \\
cubic foot per second $\left(\mathrm{ft}^{3} / \mathrm{s}\right)$ & 28.32 & meter \\
foot $(\mathrm{ft})$ & 0.3048 & meter per day \\
foot per day $(\mathrm{ft} / \mathrm{d})$ & 0.3048 & meter per year \\
foot per year $\left(\mathrm{ft}_{\mathrm{yr}}\right)$ & 0.3048 & meter squared per day \\
foot squared per day $\left(\mathrm{ft}^{2} / \mathrm{d}\right)$ & 0.0929 & meter squared per second \\
foot squared per second $\left(\mathrm{ft}^{2} / \mathrm{s}\right)$ & 0.0929 & liter per minute \\
gallon per minute $(\mathrm{gal} / \mathrm{min})$ & 3.785 & millimeter \\
inch $(\mathrm{in})$. & 25.40 & millimeter per year \\
inch per year $(\mathrm{in} / \mathrm{yr})$ & 25.40 & kilometer \\
mile $(\mathrm{mi})$ & 1.609 & square kilometer \\
square $\mathrm{mile}\left(\mathrm{mi}{ }^{2}\right)$ & 2.590 & \\
& &
\end{tabular}

Temperature: Degrees Celsius $\left({ }^{\circ} \mathrm{C}\right)$ can be converted to degrees Fahrenheit $\left({ }^{\circ} \mathrm{F}\right)$ by using the formula ${ }^{\circ} \mathrm{F}=\left[1.8\left({ }^{\circ} \mathrm{C}\right)\right]+32$. Degrees Fahrenheit can be converted to degrees Celsius by using the formula ${ }^{\circ} \mathrm{C}=0.556\left({ }^{\circ} \mathrm{F}-32\right)$.

Sea level: In this report, "sea level" refers to the National Geodetic Vertical Datum of 1929 (NGVD of 1929, formerly called "Sea-Level Datum of 1929"), which is derived from a general adjustment of the first-order leveling networks of the United States and Canada.

Metric water-quality and geophysical units:

$\mathrm{g} / \mathrm{cm}^{3}$ (gram per cubic centimeter)

$\mu \mathrm{g} / \mathrm{L}$ (microgram per liter)

$\mu \mathrm{m}$ (micrometer)

$\mu \mathrm{S} / \mathrm{cm}$ (microsiemens per centimeter at $25^{\circ} \mathrm{C}$ )
$\mathrm{mGal}$ (milliGal)

$\mathrm{mg} / \mathrm{L}$ (milligram per liter)

$\mathrm{mmol} / \mathrm{kg}$ (millimole per kilogram)
nT (nanotesla)

permil (parts per thousand)

$\mathrm{pCi} / \mathrm{L}$ (picocurie per liter) 


\title{
Water Resources and Potential Effects of Ground-Water Development in Maggie, Marys, and Susie Creek Basins, Elko and Eureka Counties, Nevada
}

\author{
By Russell W. Plume
}

\section{Abstract}

The Maggie, Marys, and Susie Creek Basins (combined area, about 630 square miles) are tributaries of the Humboldt River in north-eastern Nevada. The basins are along part of the Carlin trend, an area of large, low-grade gold deposits. In the Maggie Creek Basin, pumping of ground water at the Gold Quarry mine, including dewatering of the open pit, is expected to affect ground-water levels, streamflow, and the flow of Carlin spring, which is the water supply for the town of Carlin, Nevada.

Bedrock forms two structural basins in the Maggie Creek study area. One underlies the topographic basin of upper Maggie Creek, and contains as much as 7,000-8,000 feet of basin-fill deposits. The other structural basin underlies the topographic basins of lower Maggie Creek and adjacent parts of Marys Creek and Susie Creek Basins, and contains as much as 4,000 feet of the deposits. The principal aquifers in the study area are in basin-fill deposits.

A combination of geologic, hydrologic, and geochemical evidence supports the following conclusions regarding ground-water flow and streamaquifer relations in the study area: (1) Ground water flows from recharge areas in the Tuscarora and Independence Mountains and unnamed hills northeast of Maggie Creek canyon toward upper Maggie Creek, and discharges as evapotranspira- tion and as inflow to the stream channel; (2) bedrock of Schroeder Mountain is sufficiently permeable that small amounts of ground water flow from the upper Maggie Creek Basin to the lower basin; (3) ground water in the combined area of the lower Maggie Creek Basin and adjacent parts of the Marys and Susie Creek Basins flows south and southeast to the main discharge area along the Humboldt River; (4) a large part of ground-water recharge in the lower Maggie Creek Basin comes from infiltration of streamflow along lower Maggie Creek; and (5) volcanic rocks interbedded with basin-fill deposits function as a permeable drain through which streamflow losses from lower Maggie Creek flow southward into Marys Creek Basin and discharge at Carlin spring.

The only source of water to the combined area of the Maggie, Marys, and Susie Creek Basins is an estimated 420,000 acre-feet per year of precipitation (there is no evidence of ground-water underflow from basins adjacent to the study area). Streamflow runoff from the three basins, which includes ground-water discharge to stream channels, is an estimated 38,000 acre-feet per year. The remaining 380,000 acre-feet per year is believed to be consumed as evapotranspiration of soil moisture and ground water. Ground-water recharge to the three basins, which comes from infiltration of precipitation, is an estimated 25,000 acre-feet per year. Ground water is discharged as evapotranspiration (11,000 acre-feet per year) and as spring- 
flow and inflows to the Humboldt River channel (7,000 acre-feet per year), for a total of 18,000 acre-feet per year. The estimate of recharge exceeds the estimate of discharge by 7,000 acrefeet per year. Reasons for this imbalance may be that the estimate of annual precipitation is too high or that the estimated percentage of precipitation that becomes recharge is too high. However, the estimates of discharge also could be too low.

Water levels in the study area have declined as a result of a prolonged drought and pumping at Gold Quarry mine. The effects of the drought are most apparent along stream flood plains. Near Gold Quarry mine, water levels have declined 5-10 feet at most wells and 41 feet at a well in carbonate rocks on the west side of Schroeder Mountain. Future water-level declines may be mostly in the immediate vicinity of Schroeder Mountain if the hydraulic connection between bedrock of the mountain and adjacent basin-fill deposits proves to be poor. If the hydraulic connection is better than presently thought, waterlevel declines may extend to basin-fill deposits east and west of Schroeder Mountain. Widespread water-level declines would affect the flow of upper Maggie Creek because ground-water discharge to the stream channel would be reduced or eliminated.

When pumping of ground water ceases at Gold Quarry mine, lower Maggie Creek east of Schroeder Mountain may flow only during the snowmelt runoff. Most of the baseflow of the stream could be captured where water levels decline as a result of mine dewatering. This reduction of streamflow and of recharge to the underlying aquifer eventually could affect the flow of Carlin spring. The hydrologic effects of dewatering the mine might be reduced by impounding streamflow in the Maggie Creek canyon after mining cease. Impounded water could be used as a recharge source for the area where ground-water levels decline and to maintain flow in lower Maggie Creek-a recharge source for Carlin spring. However, impoundment of streamflow would be unlikely if it affected downstream water rights.

\section{INTRODUCTION}

\section{Background}

Development of low-grade gold deposits at Schroeder Mountain in the Maggie Creek Basin, about $8 \mathrm{mi}$ northwest of Carlin, Nev. (fig. 1), began in the late 1970's at the Maggie Creek mine (Ekburg and others, 1991, p. 630). By 1986, this mine and adjacent parts of the mountain were included in the Gold Quarry mine, which is one of the largest gold mines in North America (Ekburg and others, 1991, p. 628 and 630). Annual ground-water pumpage for processing gold ore and other mining-related activities increased from 790 acre-ft in 1985 to 6,000 acre-ft in 1990. Dewatering of the Gold Quarry mine began in 1993, when the pit floor was extended below the water table. Initial pumping rates were $5,000-10,000$ acre- $\mathrm{ft} / \mathrm{yr}$ and will increase to a rate of about 70,000 acre-ft/yr in the late stages of dewatering. Mining is expected to continue until the year 2001 (C.J. Zimmerman, Newmont Gold Co., written and oral commun, 1992).

Pumping of such large volumes of ground water has caused concern regarding potential effects on the water resources of the area. Specific concerns include:

(1) Reductions of discharge at Carlin spring ${ }^{*}$, the main water supply for Carlin;

(2) increased infiltration of streamflow from Maggie Creek and the Humboldt River to underlying aquifers, which could affect downstream water uses; and

(3) uncertainty regarding the long-term response of ground water in aquifers in the area.

In response to the concerns listed above, the U.S. Geological Survey, in cooperation with the Nevada Division of Water Resources, began a study of the Maggie Creek area in August 1988. The study was made to improve understanding of water resources in the Maggie, Marys, and Susie Creek Basins (fig. 1). The study had five specific objectives:

(1) Define the hydrogeologic framework of the lower Maggie Creek area, including hydrologic characteristics, boundaries, and possible interactions of the several hydrogeologic units;

\footnotetext{
*This spring has never been formally named. It is locally referred to as railroad spring, city spring, and Carlin spring. In this report, it is referred to as Carlin spring.
} 


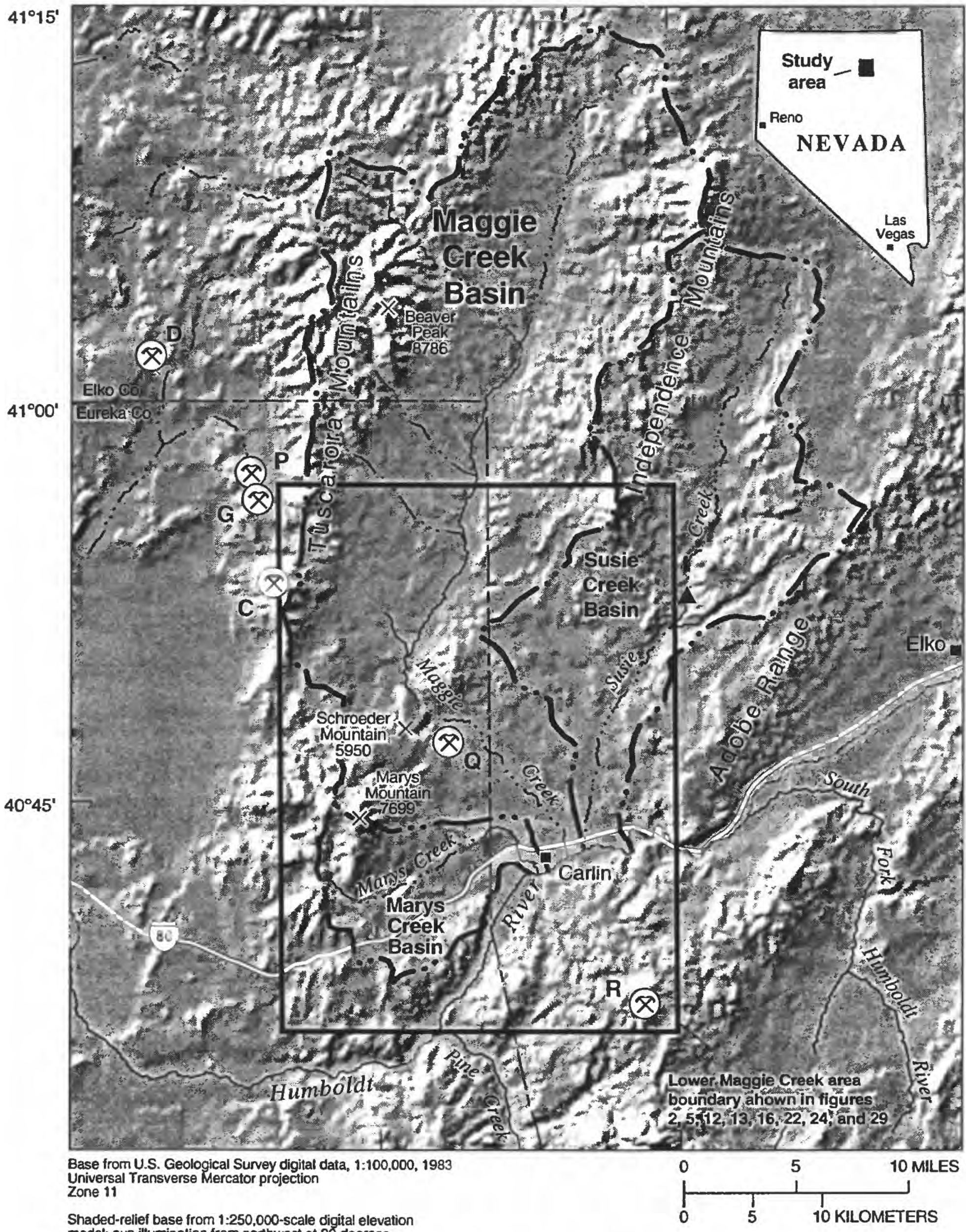

umination from northwest at 30 degrees above horizon

\section{EXPLANATION}

\section{-... Basin boundary}

- Stream-gaging station on Susie Creek near Carlin Site shown on this figure because it is beyond map area of figure 18 , which shows all other sites where streamflow is measured
( $\mathrm{R}$ Open-pit gold mine - Letter indicates mine name. From south to north, mines are: $R$ Rain Mine; Q. Gold Quarry Mine; C, Carlin Mine; G, Genesis and Blue Star Mines; P, Post-Betze Mine; and D, Dee Mine

Figure 1. Location, features, and basins of study area, northeastern Nevada. 
(2) document hydrologic conditions, including ground-water levels, water quality, streamflow, and any responses to pumping during the 1989-90 water years;

(3) update estimated water budgets for the three basins;

(4) develop a conceptual model of the flow system in the lower Maggie Creek area (fig. 2) and use it to evaluate probable effects of pumping during the anticipated life of Gold Quarry mine; and

(5) identify potential areas for artificial recharge of ground water.

\section{Purpose and Scope}

The purpose of this report is to describe the geographic and geologic setting of the entire study area, and the surface-water and ground-water resources thereof. The report presents a conceptual hydrogeologic model of the lower Maggie Creek area, describes measured and potential effects of the mining-related pumping, and discusses the potential for artificial recharge using impounded streamflow of Maggie Creek.

The geographic focus of the study was on the lower Maggie Creek area (fig. 2) where ground water pumping was concentrated. The scope of this part of the study was to evaluate existing hydrologic data and collect other data where needed.

The study also included a reconnaissance-level survey of hydrologic conditions throughout the three basins of Maggie, Marys, and Susie Creeks. The objectives for broadening the study area were twofold. First, the headwaters of the three basins are the principal source areas for ground-water recharge and streamflow. Revised water budgets could not be developed unless sources of water to each basin were identified. Second, a realistic conceptual model of the ground-water flow system in the lower Maggie Creek area could not be developed unless hydrologic conditions in adjacent areas were well understood.

\section{Study Approach}

Approaches used to accomplish the purposes listed above were to:
(1) Use geologic and geophysical information to define the hydrogeologic framework of the lower Maggie Creek area;

(2) use measurements of streamflow and groundwater levels to define flow characteristics and interactions of surface water and ground water;

(3) use geochemical data to assess sources of ground-water recharge and discharge and to evaluate possible ground-water flow paths; and

(4) develop water budgets for each of the three basins and for the entire study area.

Methods of data collection and analysis are described below.

\section{Data Collection and Analysis}

Several types of data were collected during this study. In addition, existing published and unpublished data were obtained. Most of the conclusions regarding hydrologic conditions in the study area are based on analysis of all available data. This section of the report describes the methods used to collect and analyze the data.

\section{Aquifer Tests}

Data for six aquifer tests at four wells were provided by Newmont Gold Co. As a part of the study, these data were analyzed to determine aquifer properties - transmissivity, hydraulic conductivity, and storage coefficient. A constant pumping rate and a single observation well were used for one test. For this test, a delayed-yield type curve (Lohman, 1972, p. 36-40) was used to analyze the water-level drawdown in the observation well. The other five tests were made using incremental pumping rates and are referred to as stepdrawdown tests. A pair of observation wells was used during two of the step-drawdown tests. For these two tests, water-level drawdowns in the observation wells were analyzed using a method developed by Cooper and Jacob (1946). Observation wells were not available for the other three step-drawdown tests. For these tests, the water-level recovery in the pumped well, after pumping ceased, was interpreted using a method documented by Harrill (1970). In addition, this method was used for one of the step-drawdown tests where observation wells were available, as another way of estimating transmissivity. 


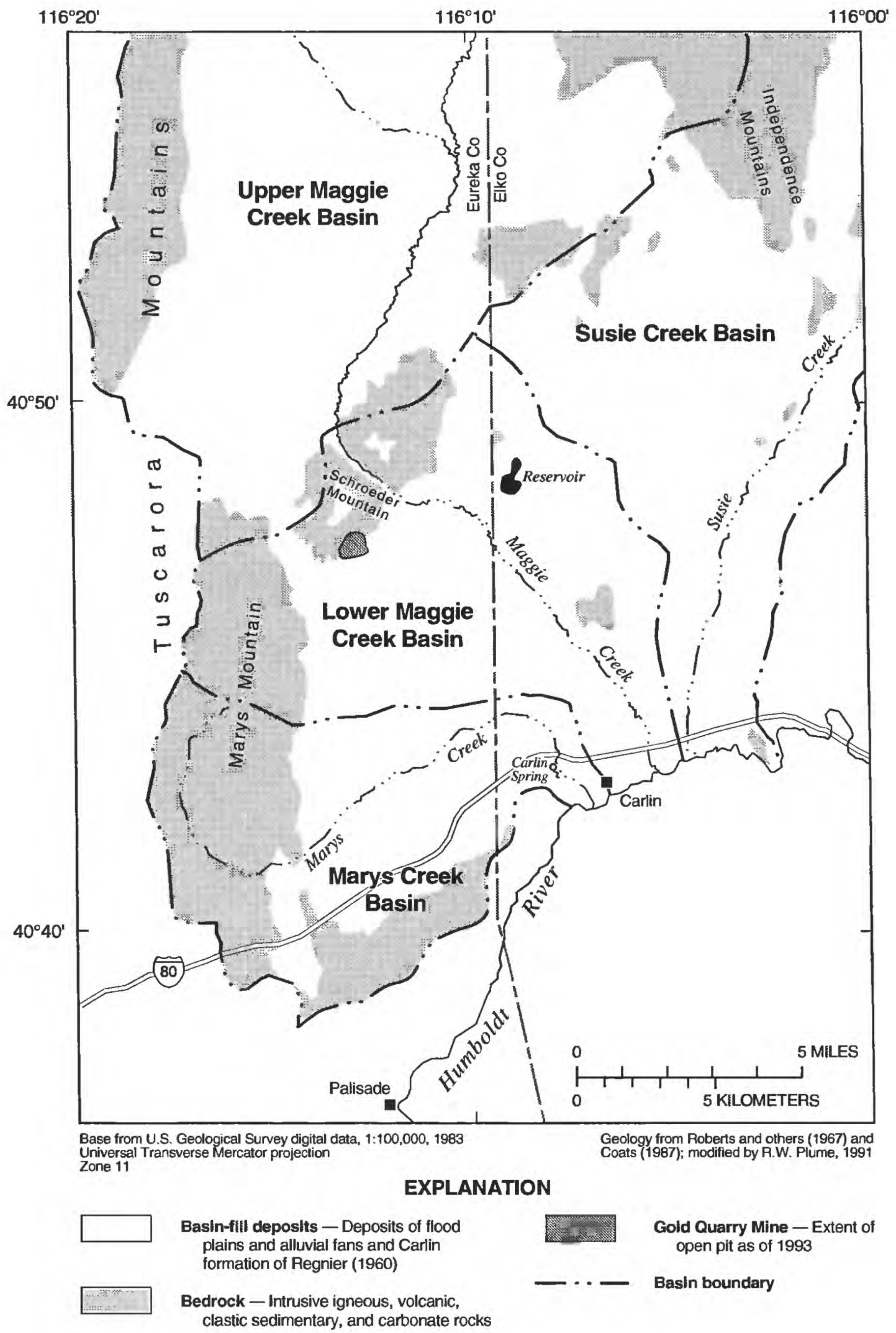

Figure 2. Features and basins of lower Maggie Creek area, northeastern Nevada. 
These methods for interpreting aquifer tests are based on several simplifying assumptions (Lohman, 1972, p. 15): (1) The aquifer is homogeneous and isotropic, (2) the ground-water body has infinite areal extent compared to the effects of the pumping well, (3) the screened interval of the pumping well penetrates the entire saturated thickness of the aquifer, (4) the diameter of the well is infinitesimal, and (5) water removed from storage is released instantaneously with decline in head. If conditions during the test violate one or more of the assumptions, interpretations based on the test could either be invalid or at least would need to be qualified. The only assumption known to be consistently violated by the tests is that of the well fully penetrating the aquifer. Thus, transmissivities determined from test results represent only a tested interval of aquifer and not its full thickness. In addition, the assumptions that the aquifers are homogeneous and isotropic and that water is released instantaneously from storage may not be entirely valid. Some of the test results may have been affected by leaky confining beds, delayed releases from storage, and flow through fractured rock.

Water-level trends before pumping, barometric effects, and influences of nearby pumping wells usually are recorded as part of a properly designed and executed aquifer test. Although information of this type was not provided, the potential effects of each can be inferred. First, water-level trends before pumping and barometric effects during pumping probably would not have caused water-level changes of more than a few tenths of a foot during the tests. In contrast, water-level declines recorded during pumping ranged from $2.5 \mathrm{ft}$ to about $325 \mathrm{ft}$. Any corrections for water-level trends before pumping or for barometric effects during pumping probably would not change the interpretations used to determine aquifer properties. Second, none of the tests are known to have been affected by nearby pumping wells.

\section{Geophysical Data}

Gravity and aeromagnetic data collected previously were used to develop a generalized understanding of the relations of the different hydrogeologic units at depth. These hydrogeologic units are described in a subsequent section of this report. Gravity data can be used to distinguish rocks or deposits of relatively low density, such as basin-fill deposits, from denser units such as those that make up bedrock. Aeromagnetic data can be used to distinguish rocks having high contents of magnetic minerals, from typically less magnetic rocks.

Gravity and aeromagnetic data were evaluated for this study using two methods. First, the data were qualitatively evaluated by visual examination of maps showing the gravity and magnetic fields in the study area. Highs and lows in the gravity and magnetic fields are referred to as anomalies. They provide information on the subsurface distribution of hydrogeologic units.

Second, the gravity and aeromagnetic data were used with a computer program (Webring, 1985) to develop two cross-sectional models. The models consist of several contiguous bodies, each representing one or more hydrogeologic units. The geometry and values of density and magnetic susceptibility for each body were repeatedly changed during the process of model development. After one or more changes were made, the program was used to calculate the gravity and magnetic profiles from the overall model. The calculated profiles were then compared to the corresponding measured profiles. This process continued until a satisfactory fit of calculated and measured profiles was achieved. An exact fit of calculated and measured profiles was never obtained because of the uncertainties involved in the process.

Geologic models developed using the methods described above can be constrained by knowledge of the geologic setting, such as thickness of hydrogeologic units, density and magnetic susceptibility of units, and by the measured profiles being used to guide the process. However, neither of the models used was very well constrained because density and magnetic susceptibility have not been measured, and the thickness of basin fill has been defined at only two wells, both in the lower Maggie Creek Basin. Surficial geology was used to constrain the models at and near land surface. Simultaneous use of gravity and magnetic data provided an additional constraint because the two provide contrasting information. However, neither of the models present unique configurations. Similar fits of calculated and measured profiles could be achieved by changing model geometries and physical properties. In spite of these limitations, both models are considered reasonable conceptualizations of the subsurface relations of bedrock and basin-fill deposits. 


\section{Streamflow}

At the beginning of the study, streamflow was being recorded at two gaging stations on the Humboldt River, near Carlin and at Palisade. Periods of record at these two stations are water year 1944 to present and water year 1903 to present, respectively. Another gaging station, on Maggie Creek near its mouth, was operated from water year 1914 to 1924 . No other streamflow data were available for the study area. Consequently, the first priority was to begin making miscellaneous streamflow measurements at selected sites. Measurements began in August 1988 at eight sites along lower Maggie Creek and in November 1988 at six sites along the Humboldt River. Additional sites were subsequently established along the river, on Marys Creek below Carlin spring, and on Susie Creek near its mouth. Streamflow measurements were made intermittently at these sites through October 1991. The measurements were made to (1) identify suitable sites for installation of recording stream gages, (2) quantify baseflow conditions of the streams, and (3) quantify gains or losses of streamflow over short reaches of Maggie Creek and the Humboldt River.

On the basis of the miscellaneous streamflow measurements, sites for three continuously recording stream gaging stations were selected in summer 1989. The gages were installed and operation began in the fall of 1989. Two of the gages were installed along Maggie Creek to measure streamflow entering the lower Maggie Creek Basin and to measure changes in streamflow in the reach of the stream next to Gold Quarry mine. The third gage was installed on Marys Creek to measure its discharge below Carlin spring.

\section{Observation-Well Network}

A network of wells for measuring water levels in the study area was established early in the fall of 1988. This network was expanded as additional wells were located and as additional observation wells were installed as part of the study. Three observation wells were installed by Newmont Gold Co. Two are near the drainage divides between Maggie and Susie Creeks and between Maggie and Marys Creeks. The third well is between lower Maggie Creek and Carlin spring. Seven other shallow observation wells were installed by the U.S. Geological Survey along Maggie Creek to monitor water levels near the stream. At the end of the study, the network included a total of more than 60 wells. Water levels at these wells were measured twice each year from late 1988 to late 1990 .

\section{Water Quality}

Defining the chemical character of ground water and surface water was important for two reasons. First, such data can be used as a basis for evaluating future changes in water quality. Second, inferred groundwater flow paths, recharge sources, and ground-water ages could be evaluated using these data. Ground water at 13 wells and 4 springs was sampled for major dissolved constituents, dissolved trace elements, dissolved nutrients, dissolved organic carbon, total and dissolved cyanide, tritium, deuterium, and oxygen-18. A radon sample was collected at Carlin spring only. At all of the sites, temperature, $\mathrm{pH}$, specific conductance, alkalinity, and dissolved oxygen were measured in the field using appropriate instruments. Alkalinity was determined by incremental titration with sulfuric acid of known concentration (Wood, 1976, p. 15-18).

Ground water at an additional well and three springs, and surface water at six sites, were sampled only for chloride, iodide, bromide, deuterium, and oxygen-18. At these sites, only temperature and specific conductance were measured in the field.

Samples for laboratory analysis were collected as follows. Water for major- and trace-constituent analyses was filtered through a $0.45-\mu \mathrm{m}$ membrane filter and collected in polyethylene bottles. Samples for cation and trace-constituent analyses were acidified to a $\mathrm{pH}$ of less than 3.0 with pure nitric acid (Wood, 1976, p. 7-9). Samples for nutrient analyses were collected in opaque polyethylene bottles, preserved with mercuric chloride, and kept at $4^{\circ} \mathrm{C}$ until the analyses were made (U.S. Geological Survey, 1990, p. 3-3). Dissolved organic carbon samples were filtered through a stainless-steel filter using a $0.45-\mu \mathrm{m}$ silver membrane filter and collected in glass bottles that had been baked at $350^{\circ} \mathrm{C}$. These samples were kept at $4^{\circ} \mathrm{C}$ from the time of collection to analysis (Wershaw and others, 1987, p. 7-8). Dissolved-cyanide samples were filtered through a $0.45-\mu \mathrm{m}$ membrane filter and collected in polyethylene bottles. Total-cyanide samples were unfiltered and were also collected in polyethylene bottles. Both totaland dissolved-cyanide samples were preserved with sodium hydroxide to a $\mathrm{pH}$ of at least 12.0 and kept at $4^{\circ} \mathrm{C}$ until the analyses were made (U.S. Geological Survey, 1990, p. 3-3). Tritium samples were unfiltered 
water collected in glass bottles. The radon sample was collected in a liquid-scintillation vial containing mineral oil. All of the samples described above were analyzed using standard methods (U.S. Geological Survey, 1990 , p. 5-5 to 5-22) at the U.S. Geological Survey laboratory in Arvada, Colo.

Deuterium and oxygen-18 samples were unfiltered water collected in glass bottles. Samples were analyzed using standard methods (U.S. Geological Survey, 1990, p. 5-9 and 5-14) at U.S. Geological Survey laboratories in Reston, Va., and Menlo Park, Calif.

\section{Acknowledgments}

The study documented in this report was made in cooperation with the Nevada Division of Water Resources. The success of the study depended, in large part, on the cooperation and assistance of many different agencies, groups, and individuals. Newmont Gold Co. provided aquifer-test data, logs for selected wells, interpretations of proprietary aeromagnetic data, and tritium analyses. In addition, the company installed three observation wells and provided equipment for excavations needed at the two stream gages installed along Maggie Creek. Three Newmont Gold Co. employees who were particularly helpful during the study are William J. Stone and Laurie Scheer Wilson, hydrologists with the company, and Charles J. Zimmerman, Manager of Hydrology.

City of Carlin employees were always ready and willing to assist in the study. Peter J. Aiazi, City Foreman, was particularly helpful. He excavated the site for installation of the Marys Creek stream gage and provided access to municipal facilities, sometimes on short notice.

Wayne Fahsholtz, manager of the Maggie Creek Ranch, and Bill Hogan, manager of the TS Ranch, granted permission for installation of the two Maggie Creek stream gages on lands owned by the respective ranches. In addition, both managers provided access to wells on ranch lands.

Several other landowners provided access to their land for measurement of water levels, streamflow, and water quality. These people are Mr. and Mrs. Tom Tomera, Rachael Jones, Mr. and Mrs. Ron Grube, and Dave Strachen.
The assistance of James M. Thomas, geochemist with the U.S. Geological Survey in Carson City, also is acknowledged. He provided guidance needed for analysis of the geochemical data.

\section{PHYSICAL SETTING}

\section{Geography}

The study area consists of the drainage basins of Maggie, Marys, and Susie Creeks ${ }^{\dagger}$, all of which are tributaries of the Humboldt River (figs. 1 and 2). The three-basin area is about $630 \mathrm{mi}^{2}$ in Elko and Eureka Counties and is along the Carlin trend, a structurally controlled, northwest-trending alignment of low-grade gold deposits (Knutsen and Wilson, 1990). Gold Quarry mine, the only active gold mine in the study area, is in the Maggie Creek Basin, about $8 \mathrm{mi}$ northwest of the town of Carlin (figs. 1 and 2). The 1990 population of Carlin was 2,220 (U.S. Bureau of the Census, 1992); however, several thousand people, most of whom live in Elko, are employed along the Carlin trend at Gold Quarry mine and at other mines outside the study area (fig. 1).

Maggie Creek Basin is the largest of the three basins, covering an area of nearly $400 \mathrm{mi}^{2}$. It consists of an upper basin and a lower basin. Upper Maggie Creek Basin trends north-northeast and is bounded on the west by the Tuscarora Mountains. The northern part of the basin is bounded on the east by the Independence Mountains. The southern part is bounded on the east by an upland consisting of unnamed hills southwest of the Independence Mountains and by Schroeder Mountain (figs. 1 and 2). This upland is informally referred to as the Schroeder Mountain uplift (C.J. Zimmerman, Newmont Gold Co., oral commun., 1994). Altitudes are $5,200-5,700 \mathrm{ft}$ above sea level along basin lowlands, 5,950 ft at Schroeder Mountain,

\footnotetext{
${ }^{\dagger}$ The three basins of the study area consist of all, or parts of, three hydrographic areas defined by Rush (1968). The Maggie Creek hydrographic area consists only of the Maggie Creek Basin The Marys Creek hydrographic area consists of the Marys Creek Basin and a small area between the southern basin boundary and the Humboldt River. The Susie Creek hydrographic area consists of the Susie Creek Basin and a small watershed to the east called the Dry Susie Creek Basin.
} 
and $8,786 \mathrm{ft}$ at Beaver Peak in the Tuscarora Mountains. Maggie Creek flows south-southwest for about $25 \mathrm{mi}$ and then turns to the southeast in a canyon that cuts between Schroeder Mountain and the unnamed hills. This canyon is informally referred to in this report as the Maggie Creek canyon.

The boundary between upper and lower Maggie Creek Basins is the topographic divide formed by the Schroeder Mountain uplift (fig. 2). Maggie Creek flows to the southeast through the canyon and across semiconsolidated sediments for about $10 \mathrm{mi}$ to the Humboldt River. Lower Maggie Creek Basin is separated from Susie Creek Basin to the east and northeast and from Marys Creek Basin to the south by low, poorly defined topographic divides.

Susie Creek Basin covers an area of about 180 $\mathrm{mi}^{2}$. This basin is oriented north-south and is about 25 mi long and 3-10 mi wide. The basin is bounded on the east by the Adobe Range and on the west by the Independence Mountains, the unnamed hills, and the topographic divide with the lower Maggie Creek Basin. Altitudes range from 4,900 to $5,900 \mathrm{ft}$ along the flood plain of the stream to more than $7,000 \mathrm{ft}$ in the Adobe Range and more than $8,000 \mathrm{ft}$ in the Independence Mountains.

The Marys Creek Basin covers about $46 \mathrm{mi}^{2}$ and is bounded to the west by Marys Mountain. The basin is oriented east-west and is about $10 \mathrm{mi}$ long and 7-8 mi wide. Altitudes range from $4,900 \mathrm{ft}$ where Marys Creek enters the flood plain of the Humboldt River to $7,699 \mathrm{ft}$ at Marys Mountain. Carlin spring, the principal water supply for the town of Carlin, is in the lower part of the basin (fig. 2).

Reference to the "lower Maggie Creek area" is made throughout much of this report. For the purpose of this study, this area is defined as consisting of the basins of lower Maggie Creek, southern parts of Susie Creek and upper Maggie Creek, and the entire basin of Marys Creek (fig. 2). The entire three-basin area (fig. 1) is referred to as the study area.

\section{Climate}

An understanding of the water resources of the study area begins with an analysis of climate because the source of all water in the area-streamflow and ground water-is precipitation, which falls as rain or snow. The study area spans two climate zones in northern Nevada: mid-latitude steppe and subhumid conti- nental (Houghton and others, 1975, p. 3). The midlatitude steppe zone has a semiarid climate. Summers in this zone are warm to hot and winters are cold; annual precipitation, as rain and snow, is 6-7 in. (Houghton and others, p. 69). The subhumid continental zone has cool to mild summers and cold winters. Annual precipitation in this zone, mostly as snow, is as much as 25 in. (Houghton and others, p. 71). The boundary between the two zones in northern Nevada (Houghton and others, p. 3 ) is at an altitude of about $6,000 \mathrm{ft}$.

The seasonal distribution of precipitation in northern Nevada depends largely on the westerly winds. These winds come out of the west and northwest during the winter and bring moisture as lowpressure air masses, which are the principal source of precipitation. These types of storms bring rain and snow to lowland areas and snow to the higher areas. The annual, high-altitude snowpack is the principal source of runoff and ground-water recharge in the study area. In addition, the low-altitude snowpack, which varies from year to year, is important because it can affect baseflow of streams.

During the summer, the westerly winds can bring warm, moist air from the Gulfs of Mexico and California and the tropical Pacific Ocean (Houghton and others, 1975, p. 10). Summer storms can be sudden and intense and produce large amounts of precipitation, mostly as rain; however, precipitation from summer storms does not constitute a large part of the annual total because such storms typically affect only small areas.

Several approaches have been used to define the distribution of precipitation in Nevada as a means of estimating potential ground-water recharge for a basin. An early approach was to subdivide the basin into precipitation zones based on the State precipitation map and to estimate potential recharge as a percentage of total precipitation in each zone (Maxey and Jameson, 1948, p. 40, and Eakin and others, 1951, p. 26-27). More recently, attempts have been made in southern and central Nevada to statistically define relations between precipitation and altitude on the basis of data from widely scattered weather stations (Quiring, 1965). However, these approaches are area specific because of the effect of latitude on winter storm tracks (see Houghton and others, 1975 , p. 8-19, for a discussion of storm tracks). 
Precipitation data for 14 stations were analyzed as a part of the present study to develop a relation between precipitation and altitude for northeastern Nevada. The data for each station are summarized in table 1 and station locations are shown in figure 3 . Figure $4 A$ is a graph on which mean annual precipitation is plotted against station altitude. The $\mathbf{1 4}$ data points are scattered closely about a straight line, which is the linear regression between the variables mean annual precipitation $(P)$ and station altitude $(A)$. The equation for this line,

$$
P=0.00356 A-8.56 \text {, }
$$

was developed using the principle of least squares (Iman and Conover, 1983, p. 360-361). The regression statistic, $\mathrm{R}$-squared $\left(\mathrm{R}^{2}\right)$, is a measure of how well the equation explains the data. A perfect fit of the line to the data gives an $\mathrm{R}^{2}$ of $1 ; \mathrm{R}^{2}$ for the line in figure $4 A$ is 0.93 (see Iman and Conover, 1983, p. 362-363, for a discussion of $\mathrm{R}^{2}$ ).

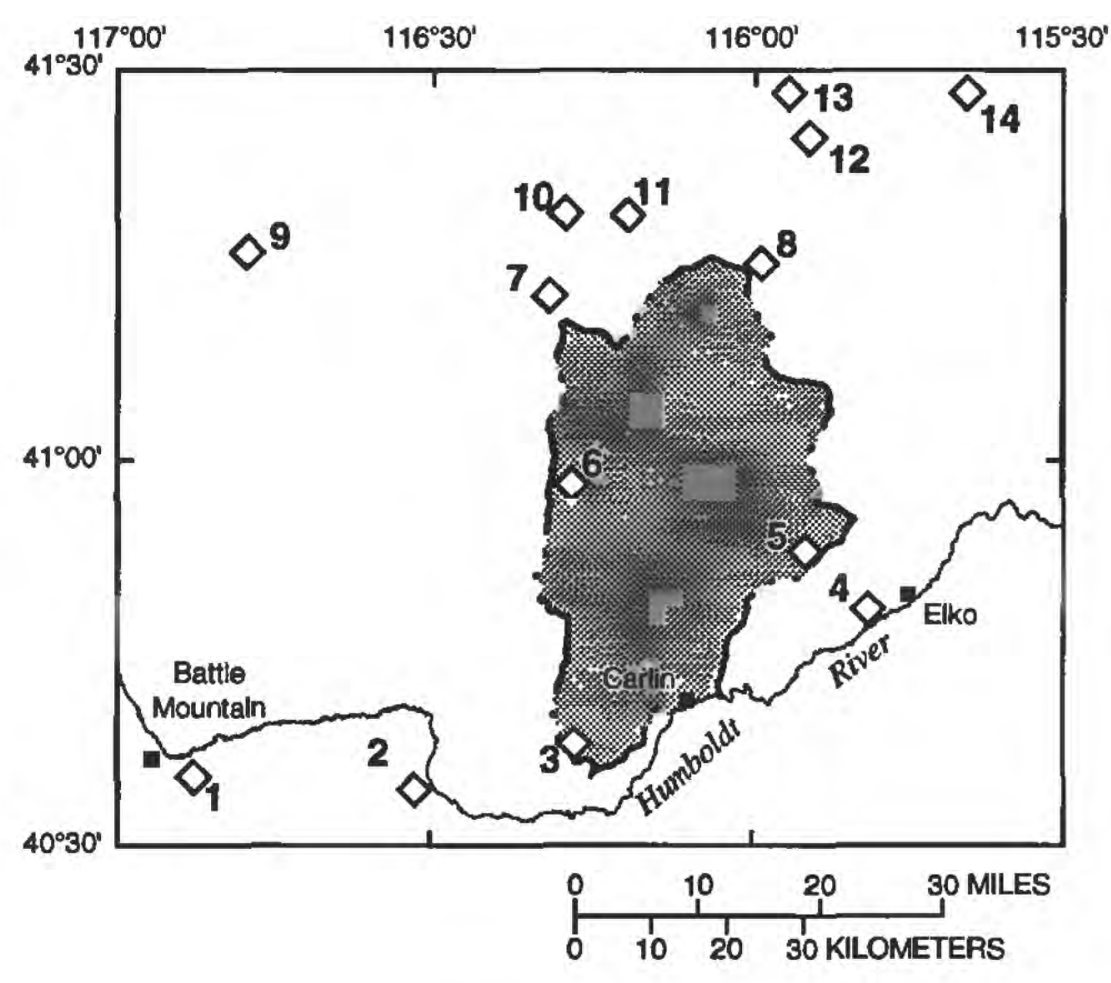

EXPLANATION

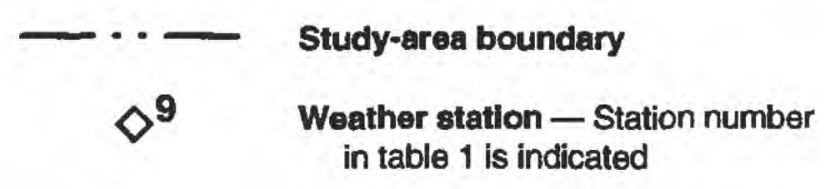

Figure 3. Locations of 14 weather stations in northeastern Nevada.

Table 1. Aititude, mean annual precipitation, and period of record for 14 weather stations in northeastern Nevada

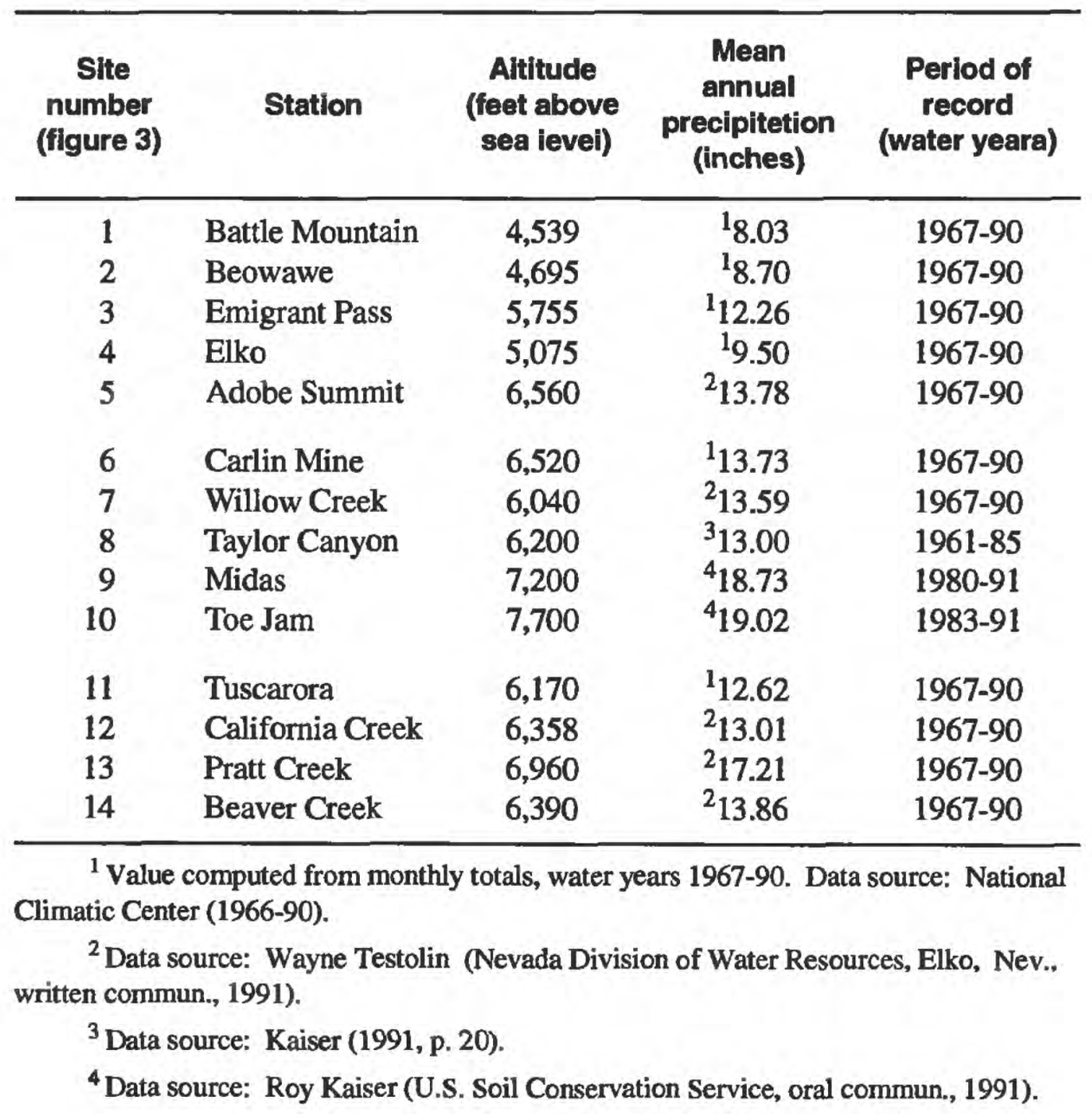


The reliability of the equation also can be evaluated by computing predicted values of mean annual precipitation using the values of station altitude. Residual values, which are the difference between measured and predicted precipitation, may then be plotted against values of predicted precipitation. The relation of residual values to predicted values is shown in figure $4 B$. This graph can be used to test for violations of several assumptions, all of which must be satisfied for a valid linear regression (see Iman and Conover, 1983, p. 366372 , for a discussion of these assumptions). All residual
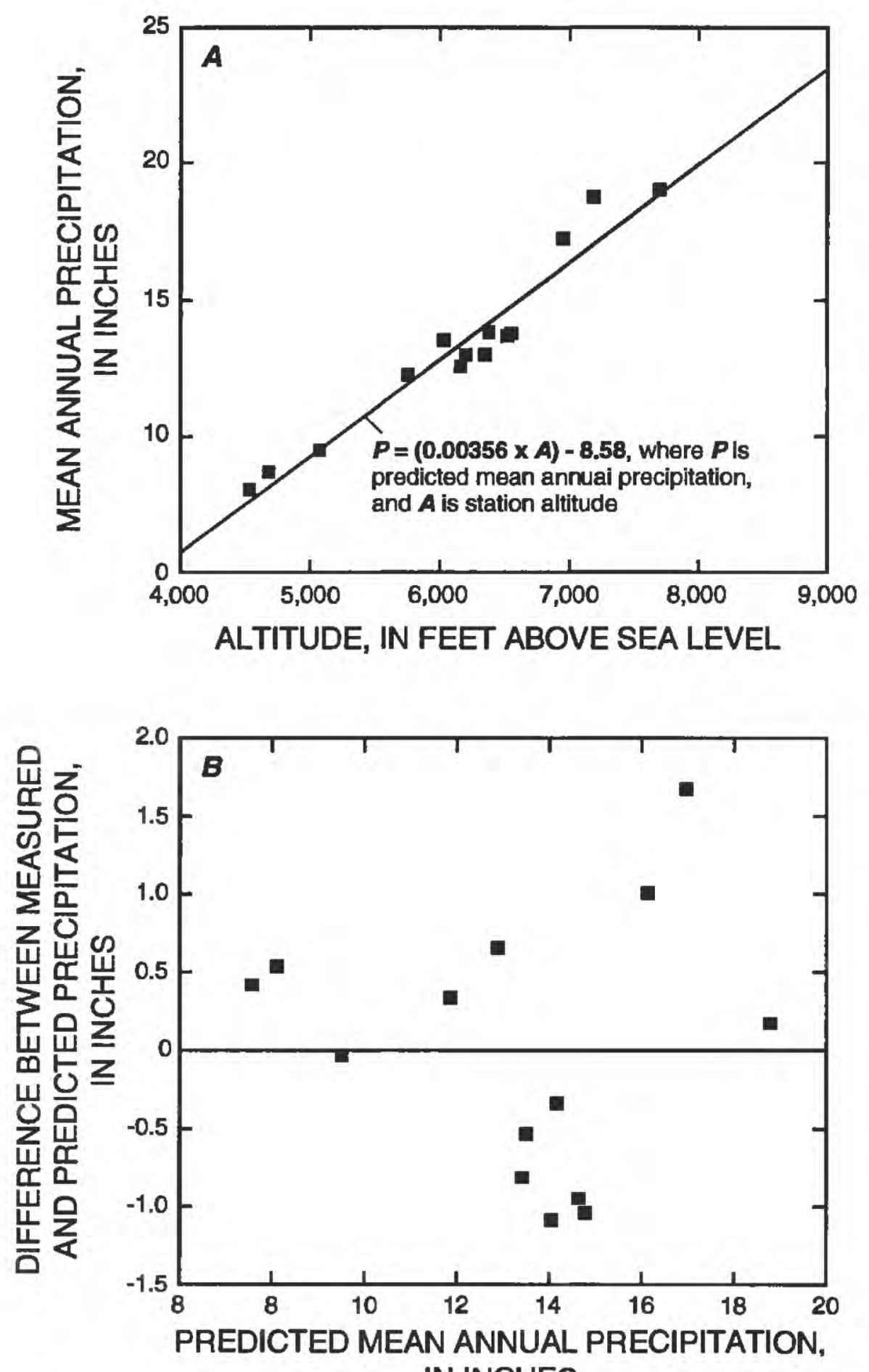

IN INCHES

Figure 4. (A) Relation of mean annual precipitation to station altitude for 14 weather stations in northeastern Nevada (locations shown in figure 3). (B) Relation of difference between predicted and measured precipitation (residual values) to predicted mean annual precipitation. values, except for one, are scattered approximately equal distances above and below zero in figure $4 B$. In addition, the graph shows no trends that suggest that any of the assumptions have been violated.

The relation described above is useful for estimating mean annual precipitation in altitude zones ranging from 4,000 to $8,000 \mathrm{ft}$ in northeastern Nevada. For altitude zones above $8,000 \mathrm{ft}$, the relation will produce estimates of annual precipitation that are increasingly uncertain. The reason for this uncertainty is that the relation is not supported by high-altitude precipitation data $(8,000 \mathrm{ft}$ and above) because such data are not available. Water budgets based in part on the relation (see sections titled "Ground Water" and "Water Budgets") are not believed to be greatly affected by the uncertainty because most of the study area is at altitudes below $8,000 \mathrm{ft}$.

\section{Hydrogeologic Units}

Rocks and deposits in the lower Maggie Creek area range in age from Cambrian to Quaternary. They are grouped into seven hydrogeologic units on the basis of hydrologic and lithologic similarities (fig. 5 and table 2). The seven units are:

(1) Carbonate rocks of Cambrian to Devonian age;

(2) clastic sedimentary rocks of Ordovician, Silurian, and Devonian age;

(3) volcanic rocks of Jurassic and Tertiary age;

(4) intrusive igneous rocks of Tertiary age;

(5) Carlin formation of Regnier (1960) of Miocene age;

(6) alluvial-fan deposits of Quaternary age; and

(7) stream flood-plain deposits of Quaternary age.

The first four units are collectively referred to as bedrock and the last three as basin-fill deposits. Bedrock forms mountain ranges and structural basins in which basin-fill deposits have accumulated. The properties and distribution of each unit are described below and summarized in table 2. 


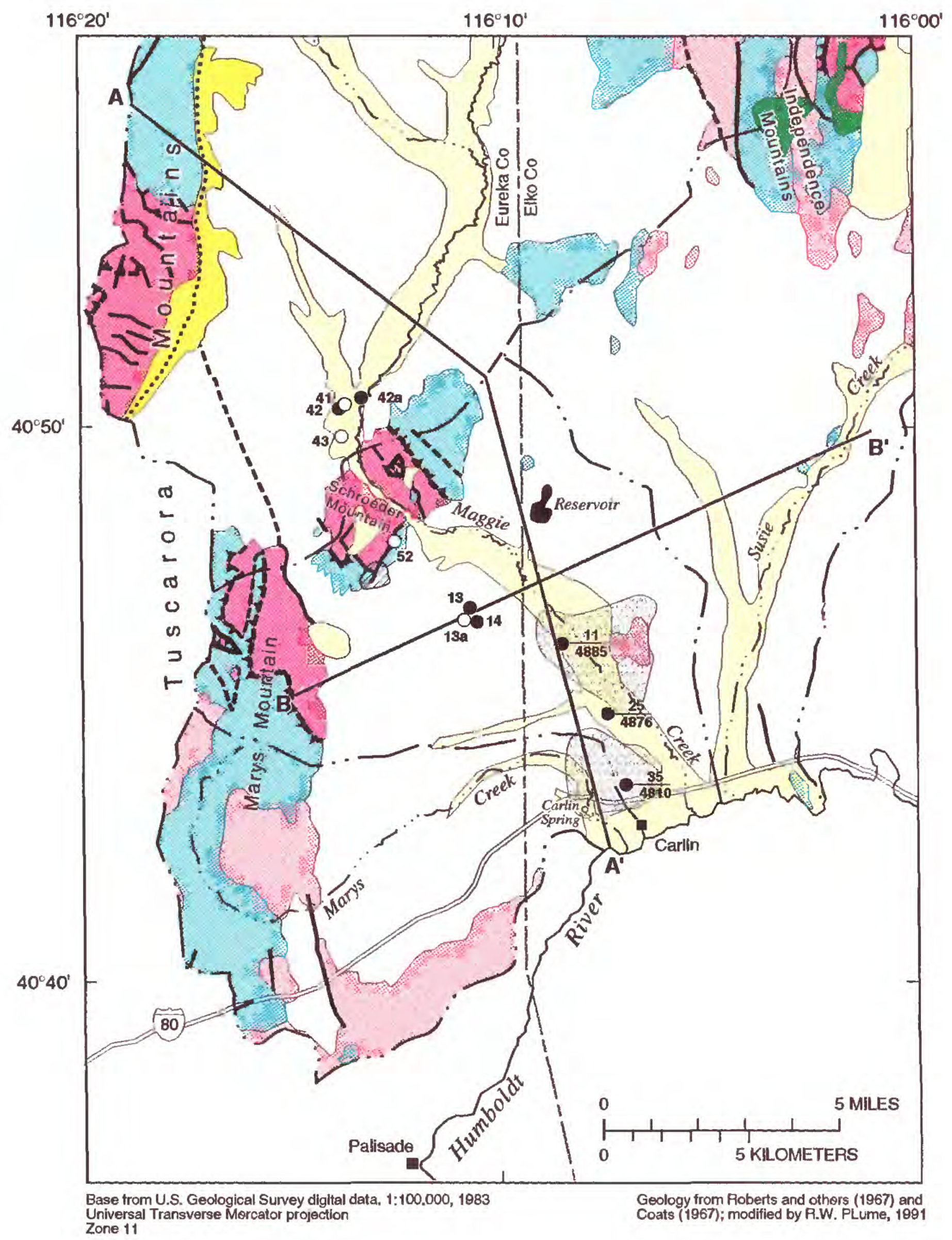

Figure 5. Hydrogeology of lower Maggie Creek area, northeastern Nevada. 


\section{EXPLANATION}

\section{BASIN-FILL DEPOSITS}

Flood-plain depostts (Quaternary) - Well to poorly sorted deposits of clay, sllt, sand, gravel, and boulders along stream flood plains. Thicknesses may range from less than 10 feet along smaller streams and a few tens of feet along Maggle, Marys, and Susle Creeks to 100 feet or more along Humboldt River

Alluvial-fan deposite (Quaternary) - Unsorted or poorly sorted deposits of clay, silt, sand, gravel, and boulders along east margin of Tuscarora Mountains. Similar deposits probably underlle area east of Marys Mountain, but have nol been mapped there

Carlin formation of Regnler (1960; Mlocene) - Interbedded sediments and volcanic rocks deposilted In lakes and streams. Includes tuffaceous slitstone, sandstone, and conglomerate, vitric tuff, thin dlatomite beds, and basaltic tuff

\section{BEDROCK}

Intrusive Igneoue rocks (Tertlary) - Quartz porphyry In Independence Mountains and dlorlte on Marys Mountain

Volcanlc rocks (Tertlary) - Solld red pattern shows mapped extent. Stippled gray pattem shows extent at land surface and in subsurface based on Interpretatlon of proprietary aeromagnetlc data (T.V. Wels, Newmont Exploration Limited. written commun., 1990). Includes Palisade Canyon Rhyolite along Humboldt River west of Carllin, basaltic andesite flows interbedded with Carlin formation of Regnler (1960) In lower Maggie Creek area, latite flows along crest of Marys Mountain and In Independence Mountains, and Frenchie Creek Rhyolite on south side of Marys Mountaln

Claetlc sedimentary rocks (Devonlan, Silurlan, and Ordoviclan) - Mudstone, shale, chert, siltstone, gray quartzite. plllow lava, and minor limestone. Includes Woodruff Formation, Slaven Chert, and Vininl Formation

Carbonate rocks (Devonian to Cambrlan) - Limestone, dolomlte, quartzite, and shale. Exposed parts of unit Include Rodeo Creek unit of Ettner (1989), Popovich Formation, Roberts Mountain Formation, Hanson Creek Formation, Eureka Quartzite, Pogonip Group, and Hamburg Dolomite. Probably also includes unexposed underlying units of limestone, dolomite, and shale

\section{OTHER SYMBOLS}

Gold quarry mine - Extent of open plt as of 1993

High-angle fault — Dashed where approximately located; dotted where inferred

Thrust fauit — Sawteeth on upper plate. Dashed where approximately located

$A-A^{\prime} \quad$ Location of hydrogeologic section - Section shown in figures 14, 15, and 28

Baeln boundary

Well penetrating volcanic rocks - Well number in table 13 is Indicated above lline; top of volcanlc rocks, In feet above sea level, is indicated below line

${ }^{41} \mathrm{P} \quad$ Production well for aquifer teet - Well number in tables 3 and 13 is indicated

Figure 5. Continued. 
Table 2. Summary of hydrogeologic units and their properties in lower Maggie Creek area, northeastern Nevada

[Abbreviations: ft, feet; gal/min, gallons per minute. Data sources: Regnier, 1960; Roberts and others, 1967; Coats, 1987; and Ettner, 1989]

\begin{tabular}{|c|c|c|c|c|}
\hline Perlod & $\begin{array}{c}\text { Hydrogeologle } \\
\text { unit }\end{array}$ & $\begin{array}{l}\text { Rock-stretigrsphlc } \\
\text { unit }\end{array}$ & Thlckness & $\begin{array}{l}\text { Lithology end } \\
\text { water-bearlng } \\
\text { properties }\end{array}$ \\
\hline \multicolumn{5}{|c|}{ Basin-fill deposits } \\
\hline \multirow{2}{*}{ 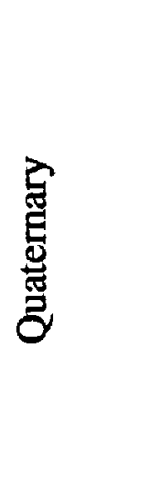 } & $\begin{array}{l}\text { Flood-plain } \\
\text { deposits }\end{array}$ & $\begin{array}{l}\text { Flood-plain } \\
\text { deposits }\end{array}$ & $\begin{array}{l}\text { Few tens of feet along } \\
\text { small streams to per- } \\
\text { haps hundreds of feet } \\
\text { along Humboldt River. }\end{array}$ & $\begin{array}{l}\text { Sorted to poorly sorted clay, silt, sand, } \\
\text { gravel, and boulders. Contain shallow } \\
\text { water-table aquifers. }\end{array}$ \\
\hline & $\begin{array}{l}\text { Alluvial-fan } \\
\text { deposits }\end{array}$ & $\begin{array}{l}\text { Alluvial-fan } \\
\text { deposits }\end{array}$ & $\begin{array}{l}\text { Zero at basin margins to } \\
\text { hundreds of feet. }\end{array}$ & $\begin{array}{l}\text { Unsorted to poorly sorted clay, silt, sand, } \\
\text { gravel, and boulders. Upper parts of } \\
\text { unit in unsaturated zone. Where satu- } \\
\text { rated, permeability may range through } \\
\text { several orders of magnitude because } \\
\text { unit is so heterogeneous. }\end{array}$ \\
\hline 密 & $\begin{array}{l}\text { Carlin } \\
\text { formation } \\
\text { of Regnier } \\
(1960)\end{array}$ & $\begin{array}{l}\text { Carlin } \\
\text { formation } \\
\text { of Regnier } \\
(1960)\end{array}$ & $\begin{array}{l}8,000 \mathrm{ft} \text { in upper Maggie } \\
\text { Creek, } 2,000-4,000 \mathrm{ft} \text { in } \\
\text { lower Maggie Creek, } \\
\text { and less than } 1,000 \mathrm{ft} \\
\text { beneath Humboldt } \\
\text { River flood plain. }\end{array}$ & $\begin{array}{l}\text { Interbedded sediments and volcanic rocks } \\
\text { deposited in lakes and streams. } \\
\text { Includes siltstone, sandstone, conglom- } \\
\text { erate, ash, tuff, and lavas. Unit yields } \\
\text { water to wells at rates of less than } 100 \\
\text { gal/min to more than } 1,000 \mathrm{gal} / \mathrm{min} \text {. }\end{array}$ \\
\hline \multicolumn{5}{|c|}{ Bedrock } \\
\hline 窇 & $\begin{array}{l}\text { Intrusive } \\
\text { igneous } \\
\text { rocks }\end{array}$ & $\begin{array}{l}\text { Quartz porphyry in } \\
\text { Independence Moun- } \\
\text { tains and diorite at } \\
\text { Marys Mountain }\end{array}$ & -- & $\begin{array}{l}\text { Unit believed to be poorly permeable. } \\
\text { May be capable of yielding small quan- } \\
\text { tities of water to wells near fault zones. }\end{array}$ \\
\hline 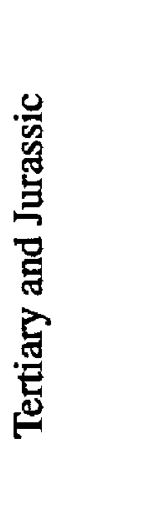 & $\begin{array}{c}\text { Volcanic } \\
\text { rocks }\end{array}$ & $\begin{array}{l}\text { Palisade Canyon Rhyo- } \\
\text { lite southwest of } \\
\text { Carlin, basaltic andes- } \\
\text { ite interbedded with } \\
\text { Carlin formation } \\
\text { along lower Maggie } \\
\text { Creek, latite at Marys } \\
\text { Mountain and Inde- } \\
\text { pendence Mountains, } \\
\text { and Frenchie Creek } \\
\text { Rhyolite at Marys } \\
\text { Mountain. }\end{array}$ & $200-500 \mathrm{ft}$ & $\begin{array}{l}\text { Mostly flows with lesser amounts of tuff. } \\
\text { Discharge of Carlin spring closely asso- } \\
\text { ciated with volcanic rocks. Irrigation } \\
\text { wells finished partly in volcanic rocks } \\
\text { near lower Maggie Creek yield as much } \\
\text { as } 2,000 \mathrm{gal} / \mathrm{min} \text {. }\end{array}$ \\
\hline 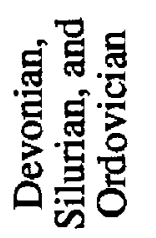 & $\begin{array}{l}\text { Clastic } \\
\text { sedimentary } \\
\text { rocks }\end{array}$ & $\begin{array}{l}\text { Includes Woodruff } \\
\text { Formation, Slaven } \\
\text { Chert, and Vinini } \\
\text { Formation }\end{array}$ & $1,600 \mathrm{ft}$ & $\begin{array}{l}\text { Chert, mudstone, shale, and calcareous } \\
\text { siltstone. Water-bearing properties } \\
\text { unknown. }\end{array}$ \\
\hline 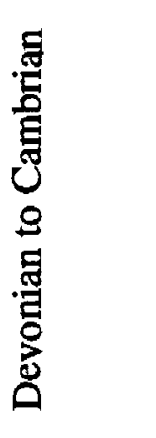 & $\begin{array}{l}\text { Carbonate } \\
\text { rocks }\end{array}$ & $\begin{array}{l}\text { Rodeo Creek unit of } \\
\text { Ettner (1989), } \\
\text { Popovich, Roberts } \\
\text { Mountains, and } \\
\text { Hanson Creek Forma- } \\
\text { tions, Eureka Quartz- } \\
\text { ite, Pogonip Group, } \\
\text { and Hamburg } \\
\text { Dolomite }\end{array}$ & $\begin{array}{l}\text { Exposed parts of unit } \\
2,600-3,200 \mathrm{ft} \text { thick. } \\
\text { Total thickness includ- } \\
\text { ing unexposed parts } \\
\text { may be as much as } \\
7,000 \mathrm{ft} \text {. }\end{array}$ & $\begin{array}{l}\text { Unit structurally overlain by clastic sedi- } \\
\text { mentary rocks along Roberts Mountains } \\
\text { thrust. Consists of limestone, dolomite, } \\
\text { quartzite, sandstone, siltstone, and mud- } \\
\text { stone. Unit can be very permeable } \\
\text { where fractured along fault zones; also } \\
\text { can be poorly permeable where less } \\
\text { fractured. Yields from wells completed } \\
\text { along or near fault zones as much as } \\
3,000-4,000 \mathrm{gal} / \mathrm{min} \text {. }\end{array}$ \\
\hline
\end{tabular}




\section{Bedrock}

\section{Carbonate Rocks and Clastic Sedimentary Rocks}

Carbonate rocks and clastic sedimentary rocks, both of Paleozoic age, are the oldest hydrogeologic units in the study area. The two units are described together because of their association during deposition several hundred million years ago and because of their present structural relations.

The continental margin of western North America was in what is now the eastern Great Basin from late Precambrian time through early Mesozoic time (Stewart, 1980, p. 14-60). During part of this period, marine sedimentary rocks were deposited along a shallow continental shelf and in a deeper ocean basin on the adjacent continental slope and rise. Carbonate rocks accumulated on the continental shelf and clastic sedimentary rocks in the deeper basin. During Devonian and Early Mississippian time, the clastic sedimentary rocks were emplaced over the carbonate rocks along a thrust fault referred to as the Roberts Mountains thrust fault.

The carbonate rocks are exposed in relatively small areas called windows where structural uplift and subsequent erosion have removed the overlying clastic sedimentary rocks. Such exposures are in the Tuscarora Mountains, Independence Mountains, Schroeder Mountain, and at small areas at Marys Mountain and in the unnamed hills (fig. 5). Carbonate rocks are believed to underlie the entire area at differing depths.

The unit of carbonate rocks consists mostly of limestone and dolomite but includes minor amounts of sandstone and shale. Exposed parts of the unit range in age from Cambrian to Devonian and include the Hamburg Dolomite, Pogonip Group, Eureka Quartzite, Hanson Creek Formation, Roberts Mountains Formation, and Popovich Formation (Roberts and others, 1967, pl. 3) and the Rodeo Creek unit of Ettner (1989, p. 60-70). The combined stratigraphic thickness of these rock units is 2,600-3,200 ft (Stratigraphic Committee of the Eastern Nevada Geological Society, 1973; Ettner, 1989, p. 66). An additional 4,000 ft of mostly limestone and dolomite underlies the Hamburg Dolomite in the northern Independence Mountains 40-60 mi north of the study area and in the Roberts Mountains about $60 \mathrm{mi}$ to the south (Stratigraphic Committee of the Eastern Nevada Geological Society, 1973). Thus, the total stratigraphic thickness of the carbonate rocks in the study area, including unexposed parts, could be as much as $7,000 \mathrm{ft}$.

Analysis of an aquifer test made at a well penetrating carbonate rocks along a fault zone on the east side of Schroeder Mountain produced an estimated transmissivity of $300,000 \mathrm{ft}^{2} / \mathrm{d}$ and hydraulic conductivity of $400 \mathrm{ft} / \mathrm{d}$ (well 52, figs. 5 and 6 and table 3 ). The geologic setting suggests that the rocks yielding water to the well are highly fractured. Consequently, the assumption that the aquifer is homogeneous and isotropic may not be valid (see section in Introduction titled "Data Collection and Analysis"). Areas of high transmissivity and hydraulic conductivity in carbonate rocks at Schroeder Mountain and other parts of the lower Maggie Creek area are believed to be mostly along fault zones. Less fractured carbonate rocks in areas between fault zones are less permeable.

Clastic sedimentary rocks are of Ordovician, Silurian, and Devonian age (fig. 5 and table 2). These rocks consist of shale, siliceous shale, and chert of the Vinini Formation in the Tuscarora Mountains (Roberts and others, 1967, pl. 3); claystone, shale, mudstone, siltstone, sandy limestone, and chert at Marys Mountain (Smith and Ketner, 1975, p. 12, 17-18, and 27); and chert, shale, and limestone at Schroeder Mountain and the unnamed hills (Evans and Cress, 1972). In early studies (Roberts and others, 1967, pl. 1), the Roberts Mountains thrust fault was mapped as structurally separating the Roberts Mountains Formation (carbonate rocks) from the overlying Vinini Formation (clastic sedimentary rocks). The position of the thrust fault is now thought to be the top of the Rodeo Creek unit of Ettner (1989, p. 66).

Clastic sedimentary rocks underlie much of the study area (fig. 5). Rocks of this hydrogeologic unit were penetrated at a depth of about $820 \mathrm{ft}$ in a geothermal well drilled at Carlin High School (William E. Nork, Inc., 1985, p. 8). Similar rocks were penetrated in an observation well at Gold Quarry mine (well 13, fig. 5 and table 13) at a depth of about $835 \mathrm{ft}$. According to the driller's $\log$, the geothermal well penetrates chert, thin-bedded shale and siltstone, and limestone of the Vinini Formation at depths of 820-924 ft. The well is perforated in its lower $74 \mathrm{ft}$. Results of an aquifer test at this well produced an estimated transmissivity of about $90 \mathrm{ft}^{2} / \mathrm{d}$ and hydraulic conductivity of about $1 \mathrm{ft} / \mathrm{d}$ (William E. Nork, Inc., 1985, p. 12). 


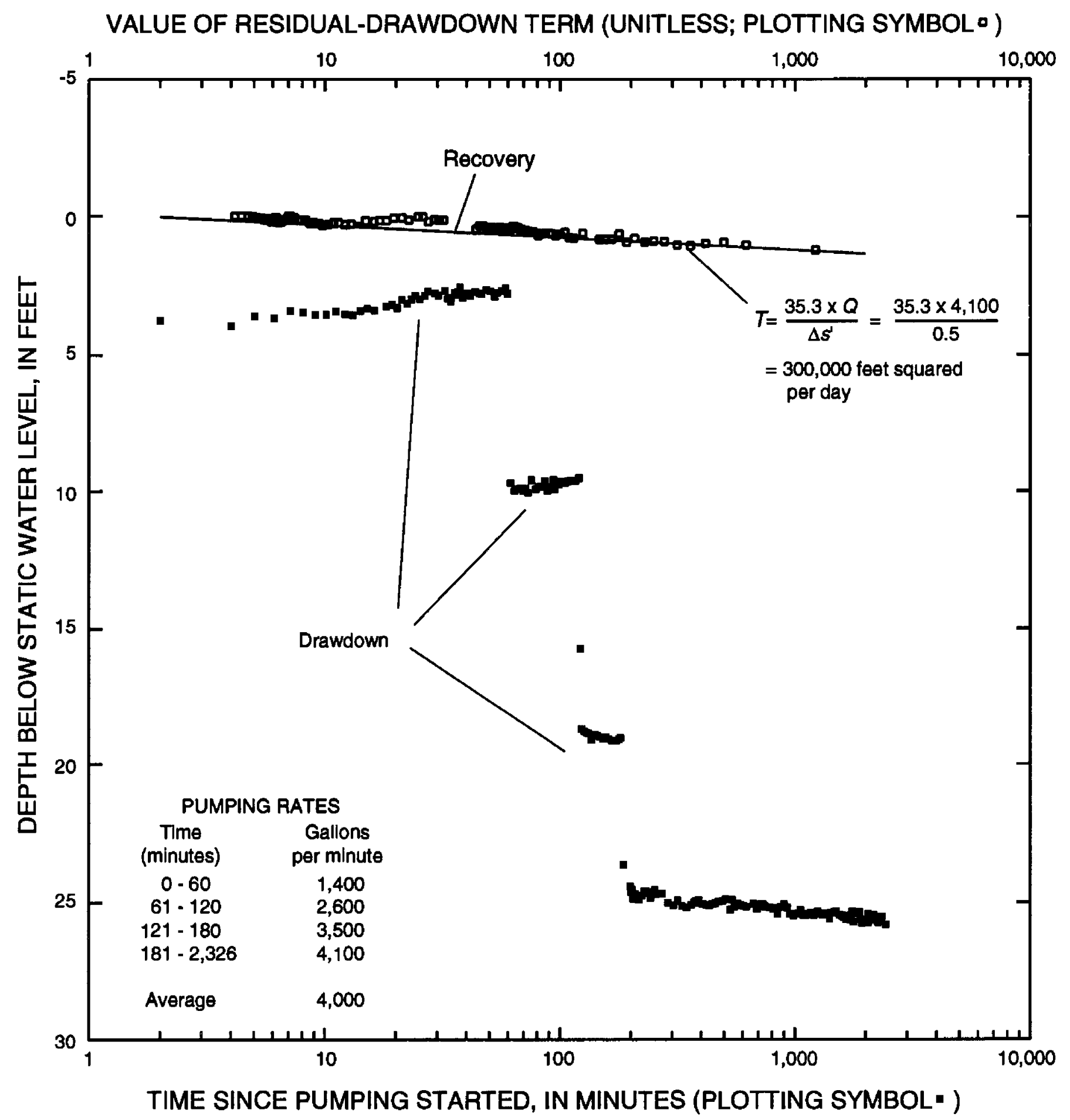

EXPLANATION

Points on drawdown curve are plotted from values of depth below static water level at time, $t$, after pumping started (iower $X$ axis). First two limbs of curve show rising water levels, probably because pumping rates at beginning of first and second pumping periods exceed average rate for each period.

Points on recovery curve are plotted from values of depth below static water level and residual-drawdown term (upper $X$ axis).

$$
\text { Residual-drawdown term }=\frac{t_{1}^{\left(\Delta Q_{1} / Q_{4}\right)}+t_{2}^{\left(\Delta Q_{2} / Q_{4}\right)}+t_{3}^{\left(\Delta Q_{3} / Q_{4}\right)}+t_{4}^{\left(\Delta Q_{4} / Q_{4}\right)}}{t^{\prime}},
$$

where $t_{1}, t_{2}, t_{3}$, and $t_{4}=$ elapsed times at end of first, second, third, and fourth pumping periods, in minutes; $Q_{4}=$ pumping rate at end of fourth pumping period, in gailons per minute; $\Delta Q_{1}, \Delta Q_{2}, \Delta Q_{3}$, and $\Delta Q_{4}=$ changes in pumping rate, in galions per minute, for each period; and $t^{\prime}=$ time since pumping stopped, in minutes.

For computation of transmissivity $(T), Q=Q_{4}$ and $\Delta s^{\prime}$ is change in depth below static water level, in feet, during water-level recovery over one logarithmic cycle of $X$ axls. Analytical method used from Harrill (1970, p. 212-213). Data source: Newmont Gold Company, Carlin, Nev. (written commun., 1989).

Flgure 6. Analysis of water-level recovery at production well 52 in lower Maggie Creek area, northeastern Nevada, after step-drawdown aquifer test (see figure 5 for well location and table 13 for well data). 
Table 3. Summary of aquifer-test results in lower Maggie Creek area, northeastern Nevada

[Abbreviations: S, step-drawdown test with no observation well; $O$, step-drawdown test with observation well; $C$, constant-discharge test with observation well; --, not available or not applicable]

\begin{tabular}{|c|c|c|c|c|c|c|c|c|}
\hline $\begin{array}{l}\text { Pumped } \\
\text { Well }{ }^{1}\end{array}$ & $\begin{array}{l}\text { Date of } \\
\text { test }\end{array}$ & $\begin{array}{l}\text { Type } \\
\text { of } \\
\text { test }\end{array}$ & $\begin{array}{c}\text { Hydrogeologlc } \\
\text { unit } \\
\text { ylelding } \\
\text { water }\end{array}$ & $\begin{array}{l}\text { Perforated } \\
\text { intervei } \\
\text { (feet) }\end{array}$ & $\begin{array}{l}\text { Observation } \\
\text { well1 }\end{array}$ & $\begin{array}{c}\text { Trensmissivity } \\
\text { (feet squared } \\
\text { per day) }\end{array}$ & $\begin{array}{l}\text { Hydrauilic } \\
\text { conductivity } \\
\text { (feet per } \\
\text { day) }\end{array}$ & $\begin{array}{l}\text { Storage } \\
\text { coefficient }\end{array}$ \\
\hline $\begin{array}{c}52 \\
\text { (figure 6) }\end{array}$ & $6 / 1-3 / 88$ & $S$ & Carbonate rocks & 803 & -- & 300,000 & 400 & -- \\
\hline $\begin{array}{c}13 a \\
\text { (figure 7) }\end{array}$ & $3 / 5-7 / 84$ & $\mathrm{C}$ & Basin-fill deposits & 410 & 13 & 870 & 2.1 & 0.0011 \\
\hline $\begin{array}{c}13 a \\
\text { (figure 8) }\end{array}$ & $4 / 30 / 84$ & $S$ & Basin-fill deposits & 410 & -- & 780 & 1.9 & - \\
\hline $\begin{array}{c}13 a \\
\text { (figure 9) }\end{array}$ & $5 / 1-4 / 84$ & $\begin{array}{l}0 \\
0\end{array}$ & Basin-fill deposits & 410 & $\begin{array}{l}13 \\
14\end{array}$ & $\begin{array}{l}1,100 \\
3,000\end{array}$ & $\begin{array}{l}2.7 \\
7.3\end{array}$ & $\begin{array}{l}.0019 \\
.0019\end{array}$ \\
\hline $\begin{array}{c}41 \\
\text { (figure 10) }\end{array}$ & $6 / 22-23 / 88$ & $\begin{array}{l}\text { S } \\
\text { O } \\
\text { O }\end{array}$ & Basin-fill deposits & 575 & $\begin{array}{l}-- \\
42 \\
42 \mathrm{a}\end{array}$ & $\begin{array}{l}2,700 \\
2,500 \\
3,600\end{array}$ & $\begin{array}{l}4.7 \\
4.3 \\
6.3\end{array}$ & ${ }_{(2)}^{.-} .0019$ \\
\hline $\begin{array}{c}43 \\
\text { (figure 11) }\end{array}$ & $6 / 24-25 / 88$ & $S$ & Basin-fill deposits & -- & -- & 1,500 & -- & -- \\
\hline
\end{tabular}

${ }^{1}$ Figure 5; table 13.

${ }^{2}$ Value computed from test results $(0.000094)$ is physically unrealistic.

\section{Volcanic Rocks}

Volcanic rocks in the lower Maggie Creek area span two separate periods of geologic time (table 2). The Frenchie Creek Rhyolite of Jurassic age is exposed on the south flank of Marys Mountain above the Humboldt River. These rocks consist of rhyolite flows, ashflow tuffs, and volcanic wackes (Roberts and others, 1967, p. 45). Younger volcanic rocks are of late Eocene or early Oligocene to late Miocene age. These rocks include flows and tuffs of latite and andesite in the Independence Mountains (Coats, 1987, pl. 1) and flows of the Palisade Canyon Rhyolite interbedded with basin-fill deposits at Marys Mountain and in southern parts of the Marys Creek Basin (Regnier, 1960, p. 1198; Smith and Ketner, 1976, p. 39).

Flows of basaltic andesite are exposed as low bluffs over a small area east of Maggie Creek about $5 \mathrm{mi}$ north of Carlin (fig. 5). These rocks are much more extensive in the subsurface and consist of two separate bodies, which slope gently southward beneath lower Maggie Creek and Marys Creek Basins
(T.V. Weis, Newmont Exploration, Limited, written commun., 1990). The southern extent of these volcanic rocks underlies the orifice of Carlin spring.

\section{Intrusive Igneous Rocks}

Intrusive igneous rocks of late Eocene or early Oligocene age are exposed in the Independence Mountains and at the south end of the Tuscarora Mountains. Those in the Independence Mountains consist of quartz porphyry (Coats, 1987, pl. 1) and in the Tuscarora Mountains consist of diorite and granodiorite (Roberts and others, 1967, p. 54). In both mountain ranges, these rocks have intruded carbonate and clastic sedimentary rocks (fig. 5). Intrusive rocks can be sufficiently fractured to yield small quantities of water to wells; however, these types of rocks generally impede the movement of ground water. No wells in the study area are known to have been finished in intrusive rocks. Thus, the capacity of these rocks to yield water to wells has not been quantified in the study area. 


\section{Basin-Fill Deposits}

Basin-fill deposits occupy structural basins as deep as 7,000-8,000 ft in parts of the lower Maggie Creek area (see section titled "Subsurface Relations of Units"). These deposits contain some of the principal aquifers in the area and are the main source of ground water except for a few high-yield wells completed in carbonate rocks.

\section{Cariin Formation of Ragnier (1960)}

Deposits of Miocene and Pliocene age along the Humboldt River in northeastern Nevada were named the Humboldt Formation (King, 1878, p. 434-443; Sharp, 1939). Similar deposits in the Carlin area and Pine Valley, south of the lower Maggie Creek area, later were named the Carlin formation (Regnier, 1960, p. 1198-1199). In an attempt to clarify discrepancies between the different names, Smith and Kettner (1976, p. 32-39) described the Humboldt Formation (restricted) on the basis of a reference section along Huntington Creek about 20 mi southeast of Carlin. They also mapped and described the Humboldt Formation (restricted) in the south part of the area shown in figure 5. Their Humboldt Formation (restricted) includes the Carlin formation of Regnier (1960). In spite of this attempt to clarify the nomenclature for the Miocene stratigraphy of the area, usage of the name Carlin formation has continued. Thus, the name is also used in this report.

The Carlin formation of Regnier (1960) was named for tuffaceous sediments exposed about $5 \mathrm{mi}$ west of Carlin and 2 mi east of Carlin along Susie Creek (Regnier, 1960, p. 1198-1199). The section west of Carlin is $625 \mathrm{ft}$ thick. The lower $214 \mathrm{ft}$ consists of lake deposits of volcanic ash and tuff interbedded with diatomite and limestone. This part of the section is overlain by $400 \mathrm{ft}$ of siltstone, sandstone, and conglomerate (Regnier, 1960, p. 1200). The section along Susie Creek consists of $176 \mathrm{ft}$ of lake deposits overlain by $325 \mathrm{ft}$ of sandstone and conglomerate for a measured thickness of $501 \mathrm{ft}$ (Regnier, 1960, p. 1200-1201). Neither section was believed to be complete.
Logs for two wells drilled in the lower Maggie Creek area include detailed descriptions of the Carlin formation of Regnier (1960). The geothermal well at Carlin High School (see section titled "Carbonate rocks and Clastic Sedimentary Rocks") penetrated about 680 $\mathrm{ft}$ of tuffaceous sandstone, siltstone, tuff, ash, clay, and limestone of the Carlin formation (William E. Nork, Inc., 1985, p. 8). According to the driller's log, the Carlin formation of Regnier (1960) rests on chert, shale, and siltstone of the Vinini Formation at a depth of $820 \mathrm{ft}$ and is overlain by about $140 \mathrm{ft}$ of clay, sandy clay, and gravel. An observation well near Gold Quarry mine (well 13, fig. 5 and table 13) penetrated about $840 \mathrm{ft}$ of claystone, siltstone, sandstone, and conglomerate of the Carlin formation of Regnier (1960). At this well, the Carlin formation of Regnier (1960) overlies argillite and quartzite (clastic sedimentary rocks) and is overlain by about $10 \mathrm{ft}$ of silty sand and gravel.

Estimates of the hydraulic properties of the Carlin formation are based on five aquifer tests made at three wells (figs. 7-11 and table 3). Estimated transmissivity ranges from 780 to $3,600 \mathrm{ft}^{2} / \mathrm{d}$; mean and median values are both $2,000 \mathrm{ft}^{2} / \mathrm{d}$. Hydraulic conductivity ranges from 2 to $7 \mathrm{ft} / \mathrm{d}$; mean and median values are 4 $\mathrm{ft} / \mathrm{d}$. Estimated storage coefficient ranges from 0.0011 to 0.0019 ; mean and median values are 0.0017 and 0.0019 , respectively.

Analysis of water-level drawdowns during two aquifer tests (figs. 7 and 9 and table 3 ) indicates that the basin-fill aquifer near production well 13a is unconfined. For a constant-discharge test, the drawdown curve at observation well 13 (fig. 7) matches a delayedyield type curve (Lohman, 1972, p. 36-40 and pl. 8) where drawdowns late in the test are less than those that would be predicted for a confined aquifer. For a subsequent step-drawdown test, the drawdown curves for observation wells 13 and 14 (fig. 9) deviate late in the test, from the middle, linear part of the curve. Storage coefficients $(0.0011,0.0019$, and 0.0019 , table 3$)$ indicate that compression of the aquifer and expansion of ground water were the sources for pumped water during most of each test. However, the source of pumped water late in each test also was drainage from aquifer pore space, which resulted in a decrease in the rate of drawdown. Test results probably would have produced storage values more representative of specific yield had the tests continued for several more days. 


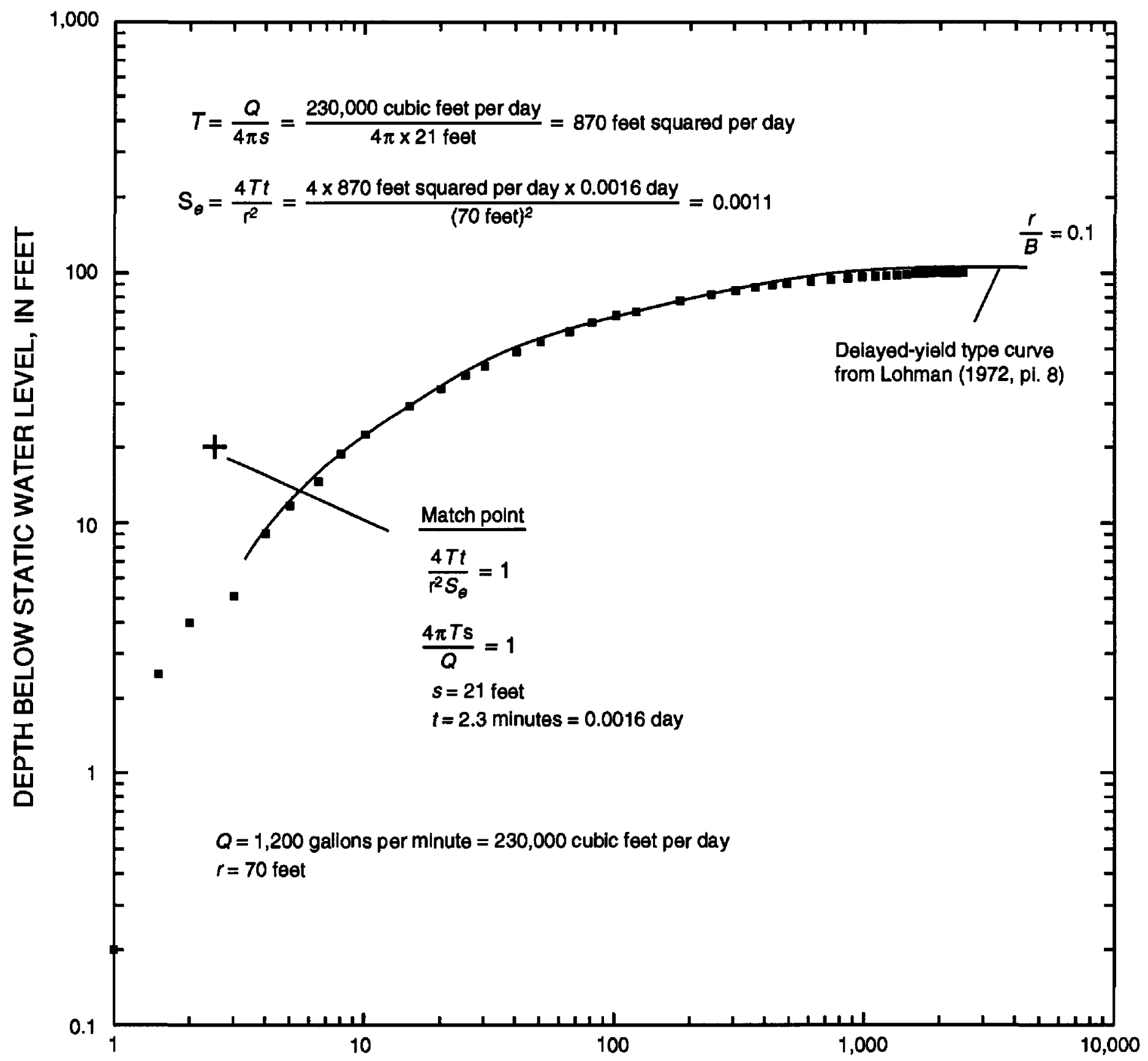

TIME SINCE PUMPING STARTED, IN MINUTES

\section{EXPLANATION}

Water-level drawdown curve matches a delayed-yield type curve where $/ / B=0.1$ (Lohman, 1972, pl. 8). At match point, values for $4 T t / r^{2} S_{\theta}$ and $4 \pi T s / Q$ were determined from the type curve (Lohman, 1972, pl. 8), and values for $s$ and $t$ were determined from the graph shown. Variable names: $T$, transmissivity, in feet squared per day; $S_{\theta}$, storage coefficient early in pumping; $Q$, discharge rate of pumping well, in cubic feet per day; $s$, depth below static water level, in feet, at observation well; $t$, time, in days, since pumping started; and $r$, distance, in feet, from observation well to pumped well. Analytical method used was for delayed yield from storage in unconfined aquifer duning early part of pumping (Lohman, 1972, p. 36-40). Data source: Newmont Gold Company, Carlin, Nev. (written commun., 1989).

Figure 7. Analysis of water-level drawdown recorded at observation well 13, in lower Maggie Creek area, northeastern Nevada, during constant-discharge aquifer test at production well 13a (see figure 5 for well locations and table 13 for well data). 


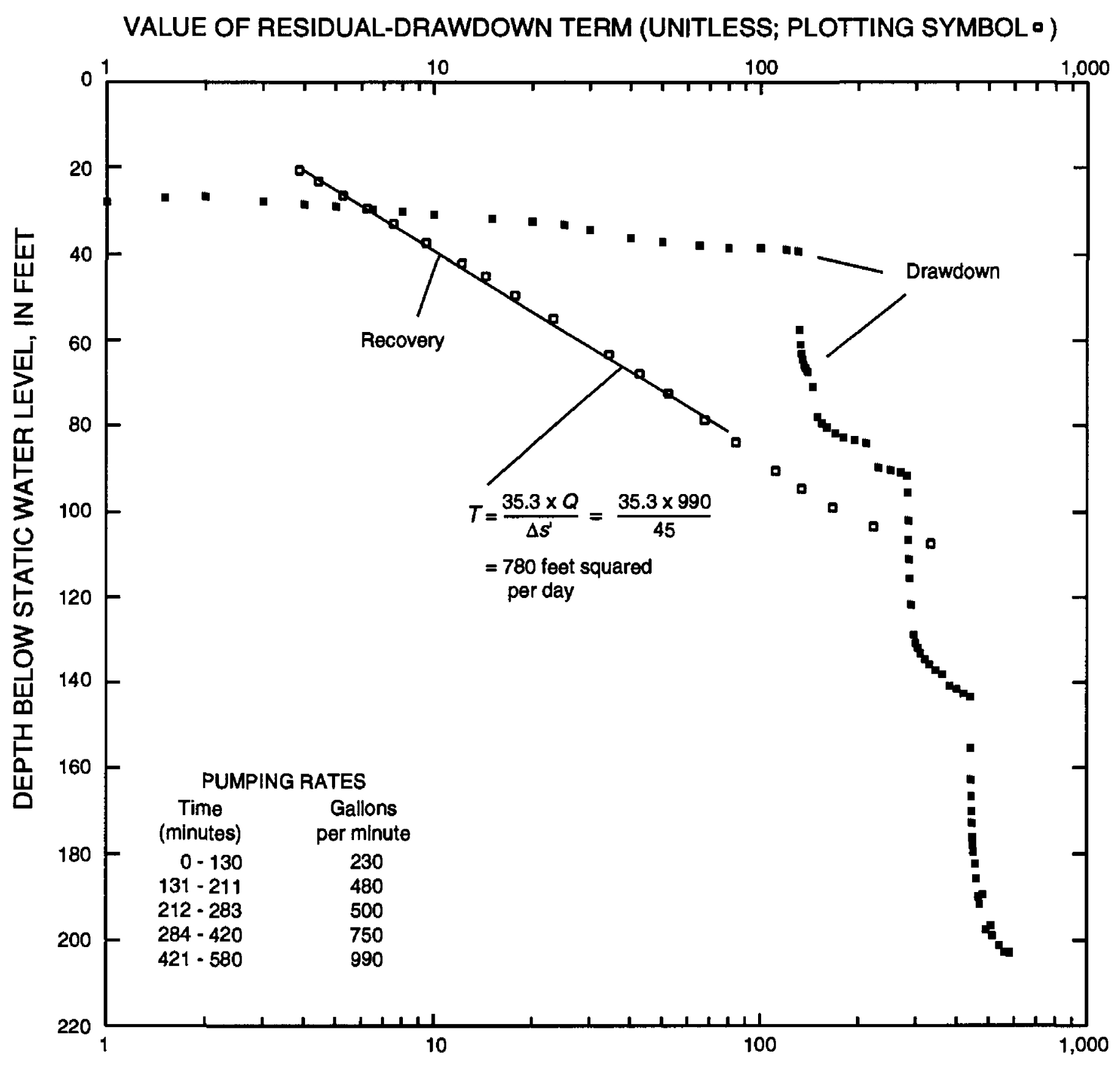

TIME SINCE PUMPING STARTED, IN MINUTES (PLOTTING SYMBOL• )

\section{EXPLANATION}

Points on drawdown curve are plotted from values of depth below static water level at time, $t$, after pumping started (lower $\mathrm{X}$ axis).

Points on recovery curve are plotted from values of depth below static water level and residual-drawdown term (upper $\mathrm{X}$ axis).

$$
\text { Residual-drawdown term }=\frac{t_{1}^{\left(\Delta Q_{1} / Q_{5}\right)}+t_{2}^{\left(\Delta Q_{2} / Q_{5}\right)}+t_{3}\left(\Delta Q_{5} / Q_{5}\right)+t_{4}\left(\Delta Q_{4} / Q_{5}\right)+t_{5}\left(\Delta Q_{5} / Q_{5}\right)}{t^{\prime}},
$$

where $t_{1}, t_{2}, t_{3}, t_{4}$, and $t_{5}=$ elapsed times at end of first, second, third, fourth, and fifth pumping periods, in minutes; $Q_{5}=$ pumping rate at end of fifth pumping period, in gallons per minute; $\Delta Q_{1}, \Delta Q_{2}, \Delta Q_{3}, \Delta Q_{4}$, and $\Delta Q_{5}=$ changes in pumping rate, in galions per minute, for each period; and $t^{\prime}=$ time since pumping stopped, in minutes.

For computation of transmissivity $(T), Q=Q_{5}$ and $\Delta s^{\prime}$ is change in depth below static water level, in feet, during water-ievel recovery over one logarithmlc cycie of $X$ axls. Analytlcai method used from Harrill (1970, p. 212-213). Data source: Newmont Gold Company, Cariin, Nev. (written commun., 1989).

Figure 8. Analysis of water-level recovery at production well 13a, in lower Maggie Creek area, northeastern Nevada, after step-drawdown aquifer test (see figure 5 for well location and table 13 for well data). 


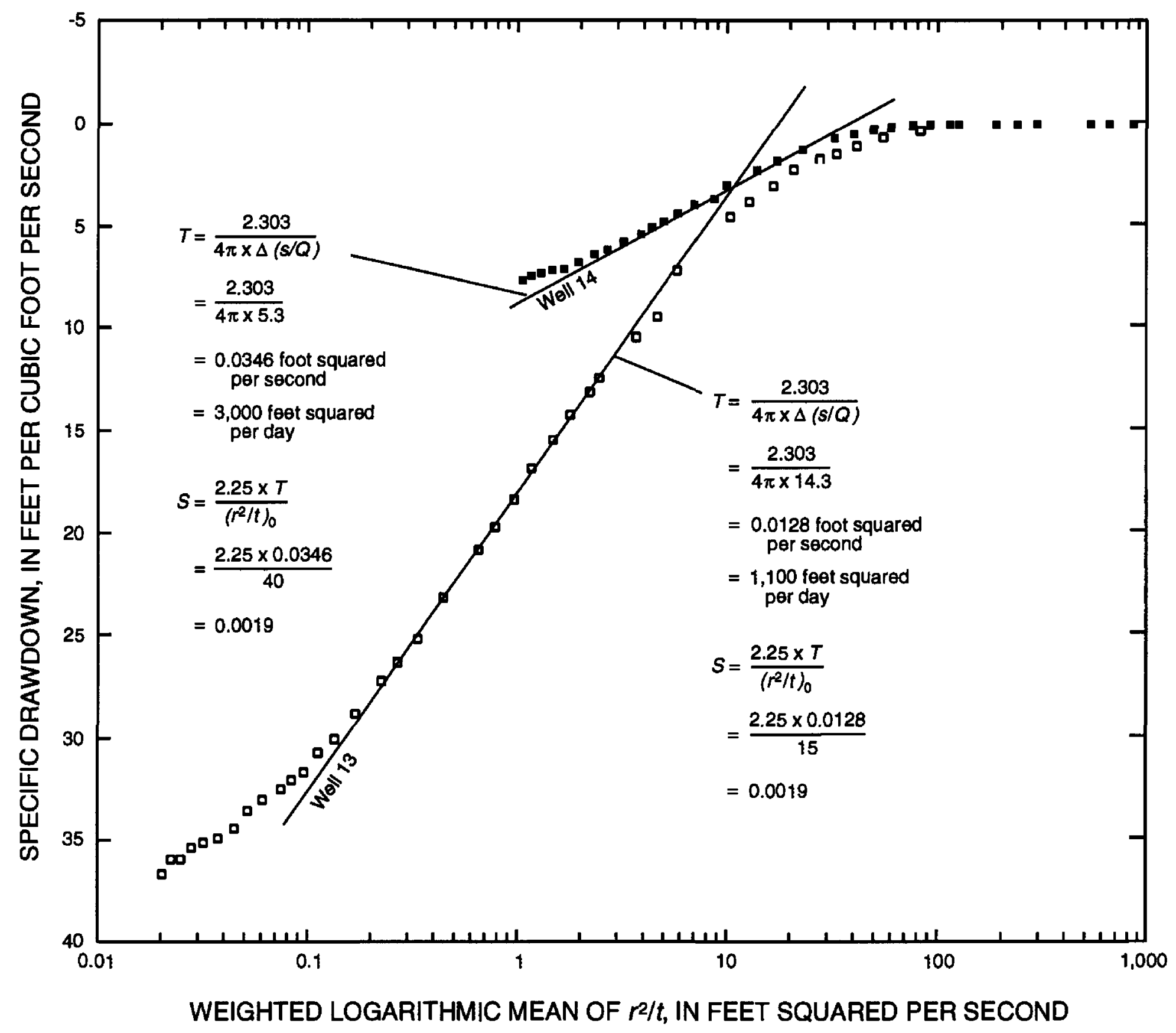

\section{EXPLANATION}

Values for speciflc drawdown ( $\mathrm{Y}$ axls) and weighted logarithmic mean of $r^{2} / t(\mathrm{X}$ axis) were computed as follows: Speciflc drawdown is ratio of water-level drawdown, $s$, to sum of all increments of pumping, $Q$, up to time water level was measured. Welghted logarithmic mean of $r^{2 / t}$ first involves caicuiation of ratio of square of $r$, distance of observatlon well to pumping well, in feet, to $t$, time, In seconds, when water level was measured. Products of each pumping increment, In cubic feet per second, and logarithm of each corresponding ratio are then summed. Sum is then divlded by sum of all prior pumping Increments to obtain value for welghted logarithmic mean of $r^{2 / t}$.

For computation of transmissivity $(T)$ and storage coefficient $(S), \Delta(s / Q)=$ change in specific drawdown, in feet per cubic foot per second, over one logarithmic cycle of $X$ axis and $\left(r^{2} / t\right)_{0}=$ weighted logarithmlc mean on straight-line part of graph, in feet squared per second, when $s / Q=0$. Analytical method used from Cooper and Jacob (1946). Data source: Newmont Gold Company, Carlin, Nov. (written commun., 1989).

Figure 9. Analysis of water-level drawdown at observation wells 13 and 14, in lower Maggie Creek area, northeastern Nevada, during step-drawdown aquifer test at production well 13a (see figure 5 for well locations and table 13 for well data). 


\section{VALUE OF RESIDUAL-DRAWDOWN TERM (UNITLESS; PLOTTING SYMBOL0)}

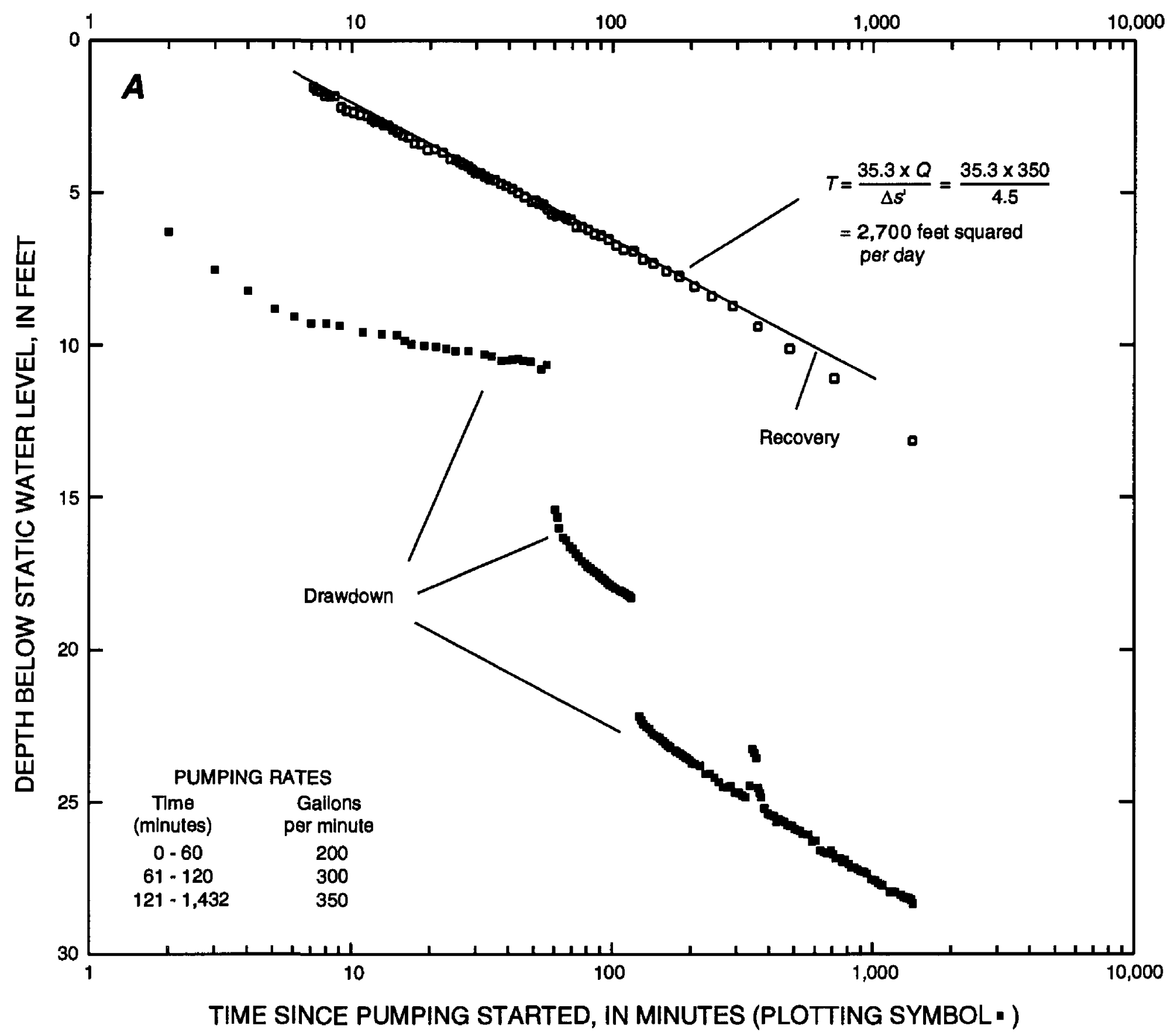

EXPLANATION

Points on drawdown curve are piotted from vaiues of depth below static water ievel at time, $t$, after pumping started (lower $X$ axis).

Polnts on recovery curve are plotted from values of depth below statlc water level and residual-drawdown term (upper $X$ axis).

$$
\text { Residual-drawdown term }=\frac{t_{1}^{\left(\Delta Q_{1} / Q_{3}\right)}+t_{2}^{\left(\Delta Q_{2} / Q_{3}\right)}+t_{3}^{\left(\Delta Q_{3} / Q_{3}\right)}}{t^{\prime}}
$$

where $t_{1}, t_{2}$, and $t_{3}=$ elapsed times at end of first, second, and third pumping perlods, In minutes; $Q_{3}=$ pumping rate at end of third pumping period, In gallons per minute; $\Delta Q_{1}, \Delta Q_{2}$, and $\Delta Q_{3}=$ changes in pumping rate, In galions per minute, for each period; and $t^{\prime}=$ time since pumping stopped, in minutes.

For computation of transmissivity $(T), Q=Q_{3}$ and $\Delta s^{\prime}$ is change in depth beiow statlc water ievel, in feet, during water-level recovery over one logarithmic cycle of $X$ axis. Analytical method used from Harrill (1970, p. 212-213). Data source: Newmont Gold Company, Carlin, Nev. (Written commun., 1989).

Figure 10. Analysis of step-drawdown aquifer test at production well 41 and observation wells 42 and $42 a$, in lower Maggie Creek area, northeastern Nevada. A, Water-level recovery at well $41 ; B$, Water-level drawdown at observation wells 42 and $42 a$ (see figure 5 for well locations and table 13 for well data). 


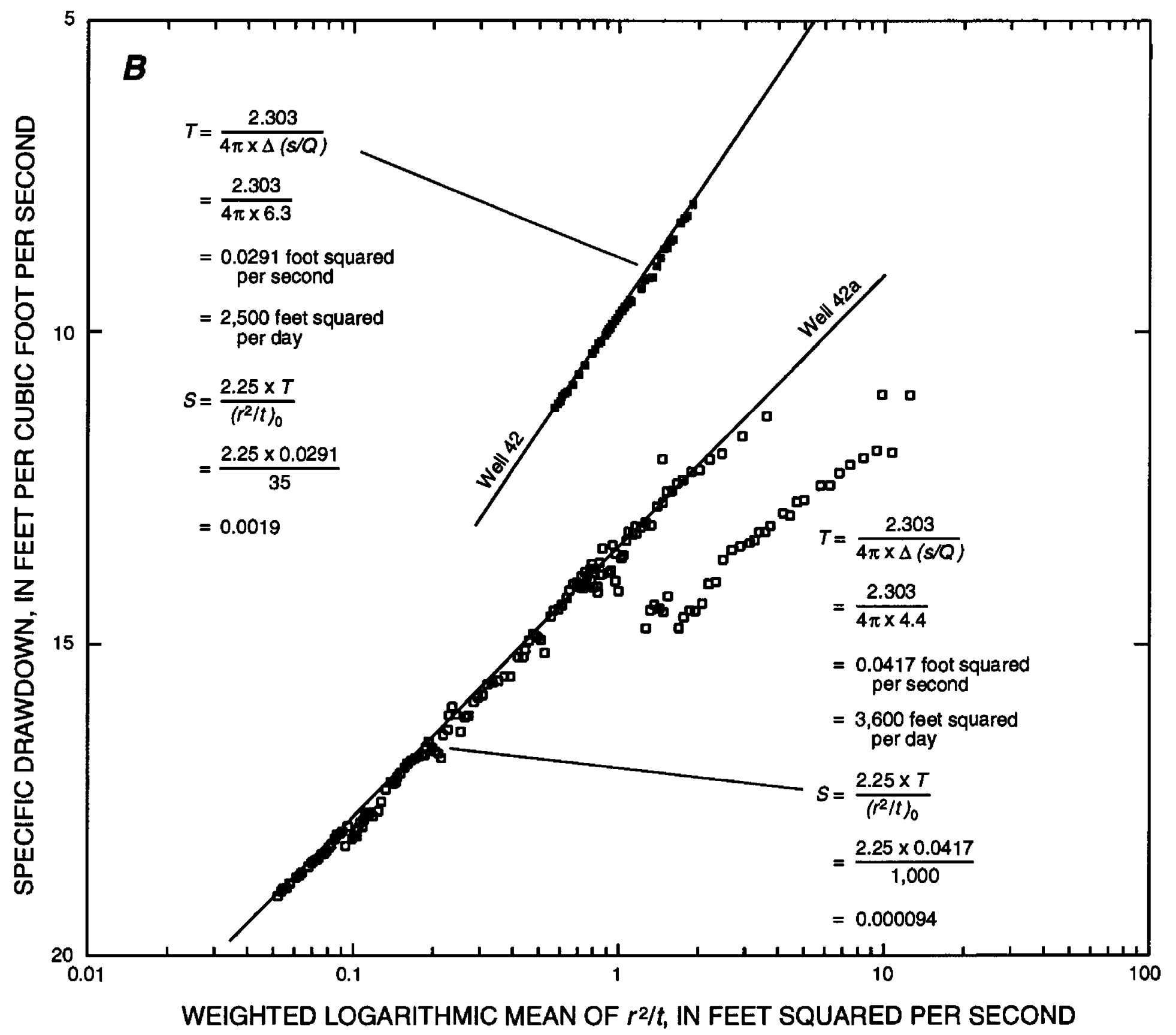

\section{EXPLANATION}

Values for specific drawdown ( $Y$ axis) and welghted logarithmic mean of $r^{2 / t}(X$ axis) were computed as follows: Specific drawdown is ratio of water-level drawdown, $s$, to sum of all increments of pumping, $Q$, up to time water level was measured. Weighted logarithmic mean of $r^{2} / t$ first involves calcuiation of ratio of square of $r$, distance of observation well to pumping weil, in feet, to $t$, time, in seconds, when water levei was measured. Products of each pumping increment, in cubic feet per second, and logarithm of each corresponding ratio are then summed. Sum is then divided by sum of all prior pumping increments to obtain value for weighted logarithmic mean of $r^{2 / t}$.

For computation of transmissivity $(T)$ and storage coefficient $(S), \Delta(S / Q)=$ change in specific drawdown, in feet per cubic foot per second, over one logarithmlc cycle of $X$ axls and $\left(r^{2} / t\right)_{0}=$ weighted logarithmic mean on straight-line part of graph, in feet squared per second, when $s / Q=0$. Analytical method used from Cooper and Jacob (1946). Data source: Newmont Gold Company, Cartin, Nev. (written commun., 1989).

Figure 10. Continued. 


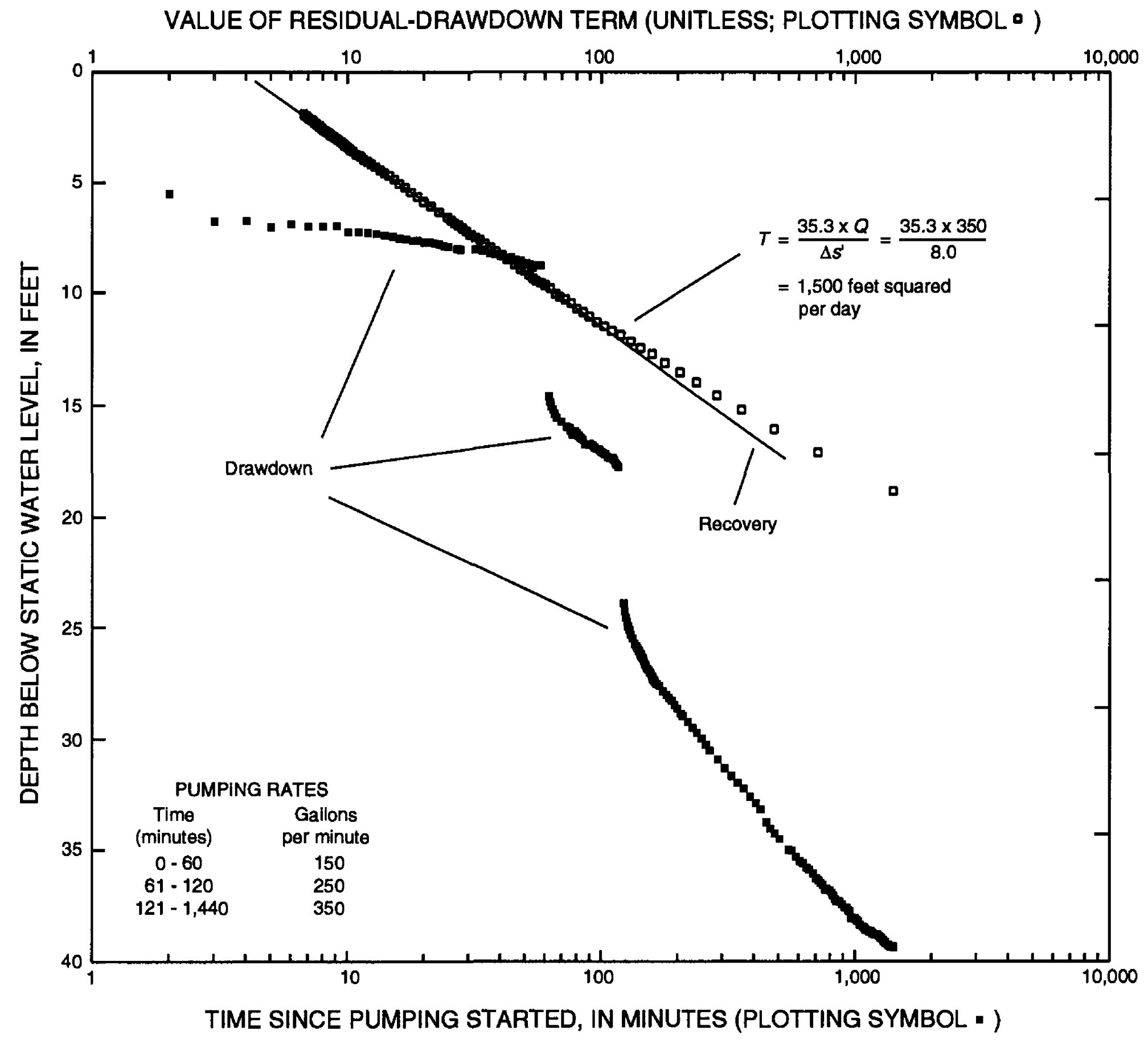

\section{EXPLANATION}

Points on drawdown curve are plotted from values of depth below static water level at time, $t$, after pumping started (lower $X$ axis).

Points on recovery curve are plotted from values of depth below static water level and residual-drawdown term (upper $\mathrm{X}$ axis).

$$
\text { Residuai-drawdown term }=\frac{t_{1}^{\left(\Delta Q_{1} / Q_{3}\right)}+t_{2}\left(\Delta Q_{2} / Q_{3}\right)+t_{3}\left(\Delta Q_{3} / Q_{3}\right)}{t^{\prime}},
$$

where $t_{1}, t_{2}$, and $t_{3}=$ elapsed times at end of first, second, and third pumping periods, in minutes; $Q_{3}=$ pumping rate at end of third pumping period, in gallons per minute; $\Delta Q_{1}, \Delta Q_{2}$, and $\Delta Q_{3}=$ changes in pumping rate, in galions per minute, for each period; and $t^{\prime}=$ time since pumping stopped, in minutes.

For computation of transmissivity $(T), Q=Q_{3}$ and $\Delta S^{\prime}$ is change in depth below static water level, in feet, during water-level recovery over one logarithmlc cycie of $X$ axis. Analytical method used from Harrill (1970, p. 212-213). Data source: Newmont Gold Company, Cariln, Nev. (written commun., 1989).

Figure 11. Analysis of water-level recovery at well 43 , in lower Maggie Creek area, northeastern Nevada, after step-drawdown aquifer test (see figure 5 for well location and table 13 for well data). 


\section{Alluviai-Fan Deposits}

The Carlin formation of Regnier (1960) is overlain by alluvial-fan deposits along the east side of the Tuscarora Mountains (fig. 5). Similar deposits probably occur along other basin margins in the study area, but may not have been mapped either because of limited extent and thickness or perhaps because they are difficult to distinguish from the Carlin formation. Alluvial-fan deposits consist of unsorted to poorly sorted mixtures, which range in size from clay to boulders. Where present in the study area, these deposits are probably above the saturated zone and, thus, may not be important sources of ground water. Where they are saturated, however, the hydraulic properties of alluvial-fan deposits probably range through several orders of magnitude because they are so heterogeneous.

\section{Fiood-Plain Deposits}

The flood plains of the Humboldt River, Maggie Creek (and its larger tributaries), Marys Creek, and Susie Creek are underlain by poorly to well-sorted deposits, which range in size from clay to gravel. The deposits commonly consist of beds of fine-grained material (clay and silt) interbedded with intervals of coarse-grained material (sand and gravel). The deposits can range in thickness from a few tens of feet or less along the smaller streams to perhaps $100 \mathrm{ft}$ or more along the Humboldt River. West of the study area, flood-plain deposits along the Humboldt River are several hundred feet thick (Bredehoeft, 1963, p. 27 and 46). In addition, these deposits are relatively permeable. Estimated transmissivity ranges from 5,000 to $50,000 \mathrm{ft}^{2} / \mathrm{d}$, and hydraulic conductivity ranges from 16 to $1,100 \mathrm{ft} / \mathrm{d}$ (Bredehoeft, 1963, p. 46).

\section{Subsurface Relations of Units}

Two types of geophysical data-gravity and aeromagnetic-were used to develop a generalized understanding of the relations of hydrogeologic units at depth in the lower Maggie Creek area. Techniques used to interpret these data are described in the "Data Collection and Analysis" section of this report.

The gravity map for the lower Maggie Creek area (fig. 12) has several anomalies related to the distribution of hydrogeologic units. The source body for the prominent gravity low in the upper Maggie Creek Basin is a thick section of basin-fill deposits, which is bounded on the east and west by denser bedrock of the Schroeder Mountain uplift and of the Independence and Tuscarora Mountains. A broad gravity high is centered over Marys Mountain, and extends to the northeast along the axis of the Schroeder Mountain uplift and Independence Mountains. The source for this high is uplifted bedrock. The source body for the poorly defined gravity low in lower Maggie and Marys Creek Basins and adjacent parts of the Susie Creek Basin also is a section of basin-fill deposits. Two small gravity highs in the southern and eastern parts of the Marys Creek Basin indicate that bedrock is relatively shallow in these parts of the basin.

Two types of magnetic anomalies are evident on the aeromagnetic map of the lower Maggie Creek area (fig. 13). One type, mostly in the southwest part of the area, is of short wavelength, low amplitude, and irregular shape. Source bodies for these anomalies are volcanic rocks on Marys Mountain. These anomalies are superimposed on, and partly obscure, a much broader anomaly. This broader anomaly extends from the southern part of Marys Mountain to the southern Tuscarora Mountains and from the west side of the lower Maggie Creek area to the west side of Marys Mountain. The source for this anomaly has been interpreted to be a large body of intrusive igneous rocks (Mabey, 1976, p. 44). The source for the smaller magnetic anomaly in the Independence Mountains also is a body of intrusive rocks, that is partly exposed nearby (figs. 5 and 13).

Subsurface relations between bedrock and basinfill deposits in the lower Maggie Creek area are illustrated by the two generalized geologic sections in figures 14 and 15 . The two sections were developed using a geophysical modeling process described in an earlier section (see "Data Collection and Analysis"). The calculated and measured gravity and magnetic profiles that accompany each geologic section were used to guide the process of model development. Section A-A' consists of two segments. The northwestern segment is perpendicular to the axis of upper Maggie Creek Basin and extends southeast from the Tuscarora Mountains to the unnamed hills northeast of Schroeder Mountain (fig. 5). The southern segment extends south-southeast across lower Maggie and Marys Creek Basins from the unnamed hills to the Humboldt River west of Carlin (fig. 5). The location and orientation of both segments were chosen to coincide, as closely as possible, with directions of ground-water flow. Section B-B' is oriented northeastward; it extends from near the foot of Marys Mountain across lower Maggie and Susie Creek Basins, and ends in the Adobe Range east of Susie Creek (fig. 5). 


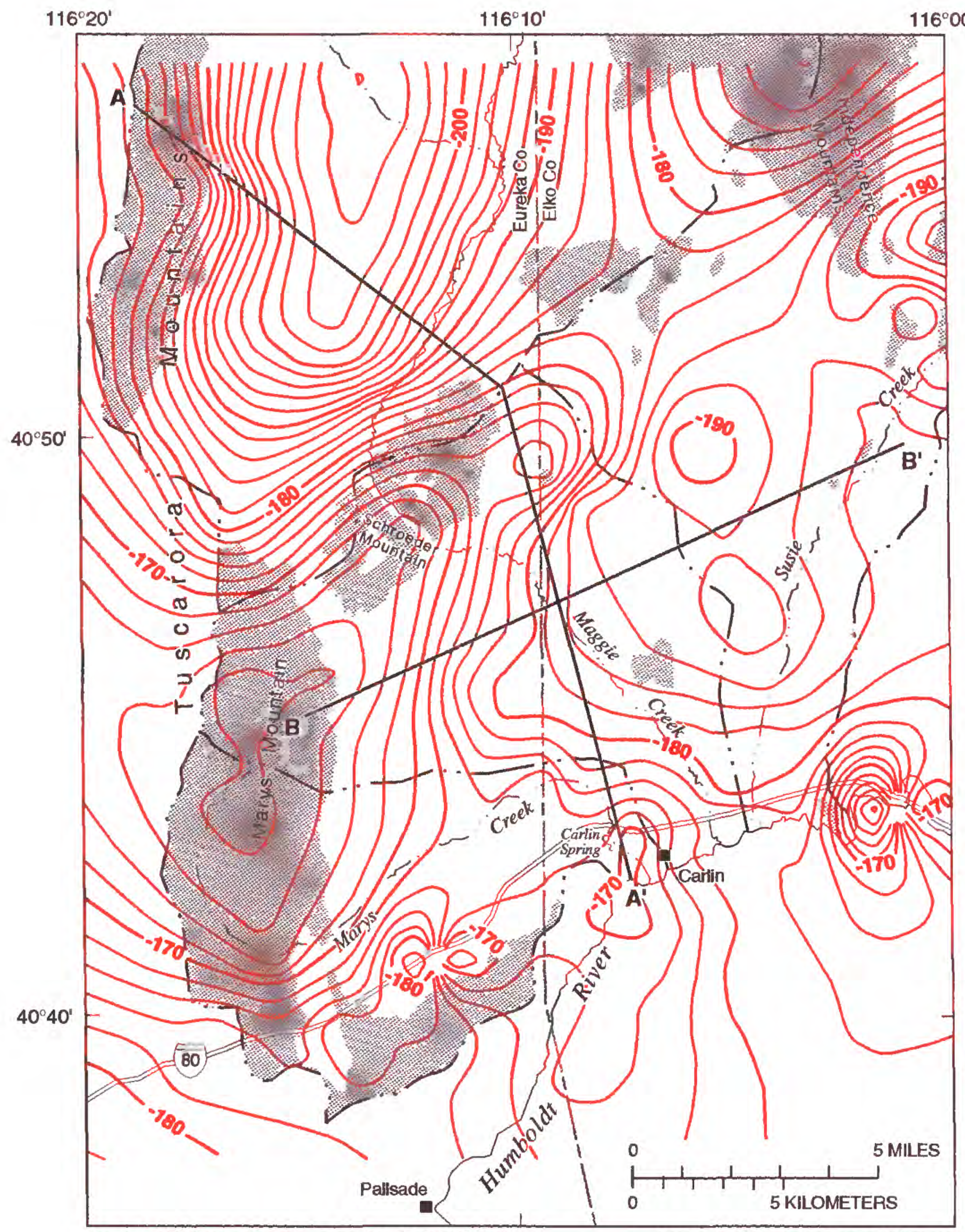

Base from U.S. Geological Survey digital data, 1:100,000, 1983 Universal Transverse Mercator projection Zone 11

\section{EXPLANATION}

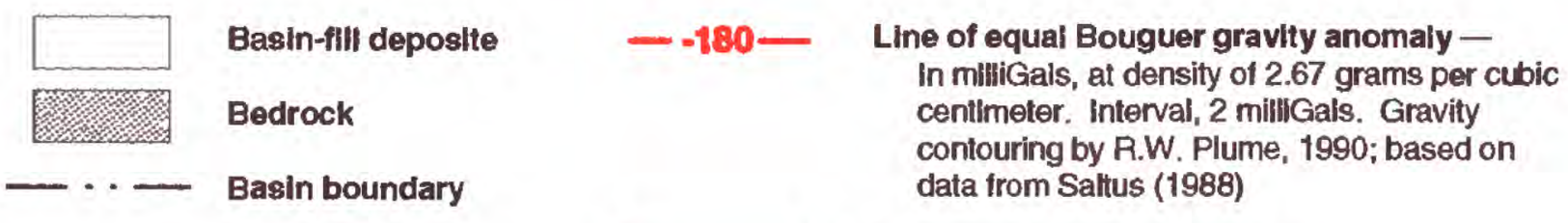

$A-A^{\prime}$ Location of geologic section

Figure 12. Complete Bouguer gravity field in lower Maggie Creek area, northeastern Nevada. 


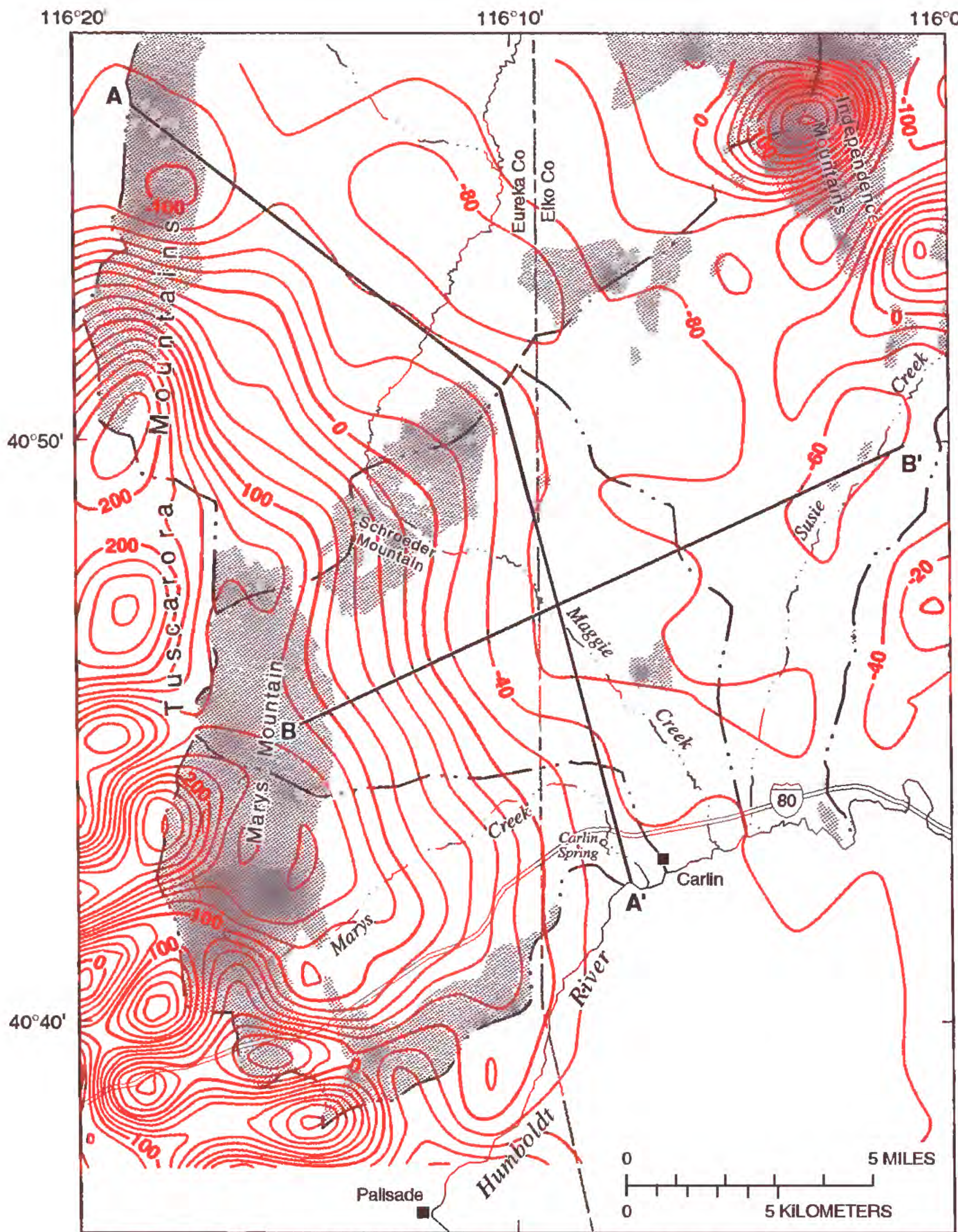

Base from U.S. Geological Survey digital data, t:100,000, 1983 Universal Transverse Mercator projection
Zone 11

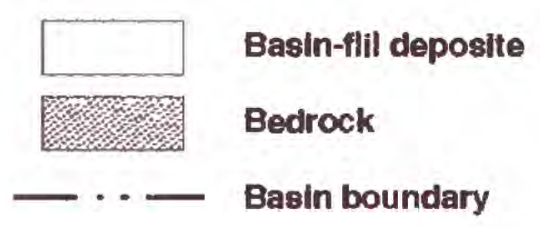

\section{EXPLANATION}

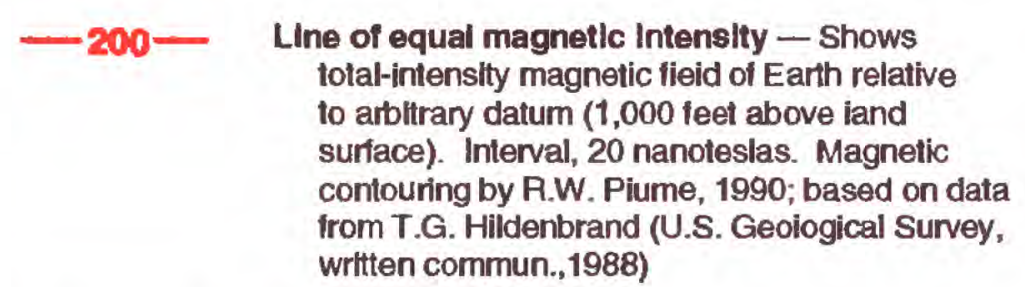

$A-A^{\prime}$ Location of geologic section

Figure 13. Total-intensity magnetic field in lower Maggie Creek area, northeastern Nevada. 

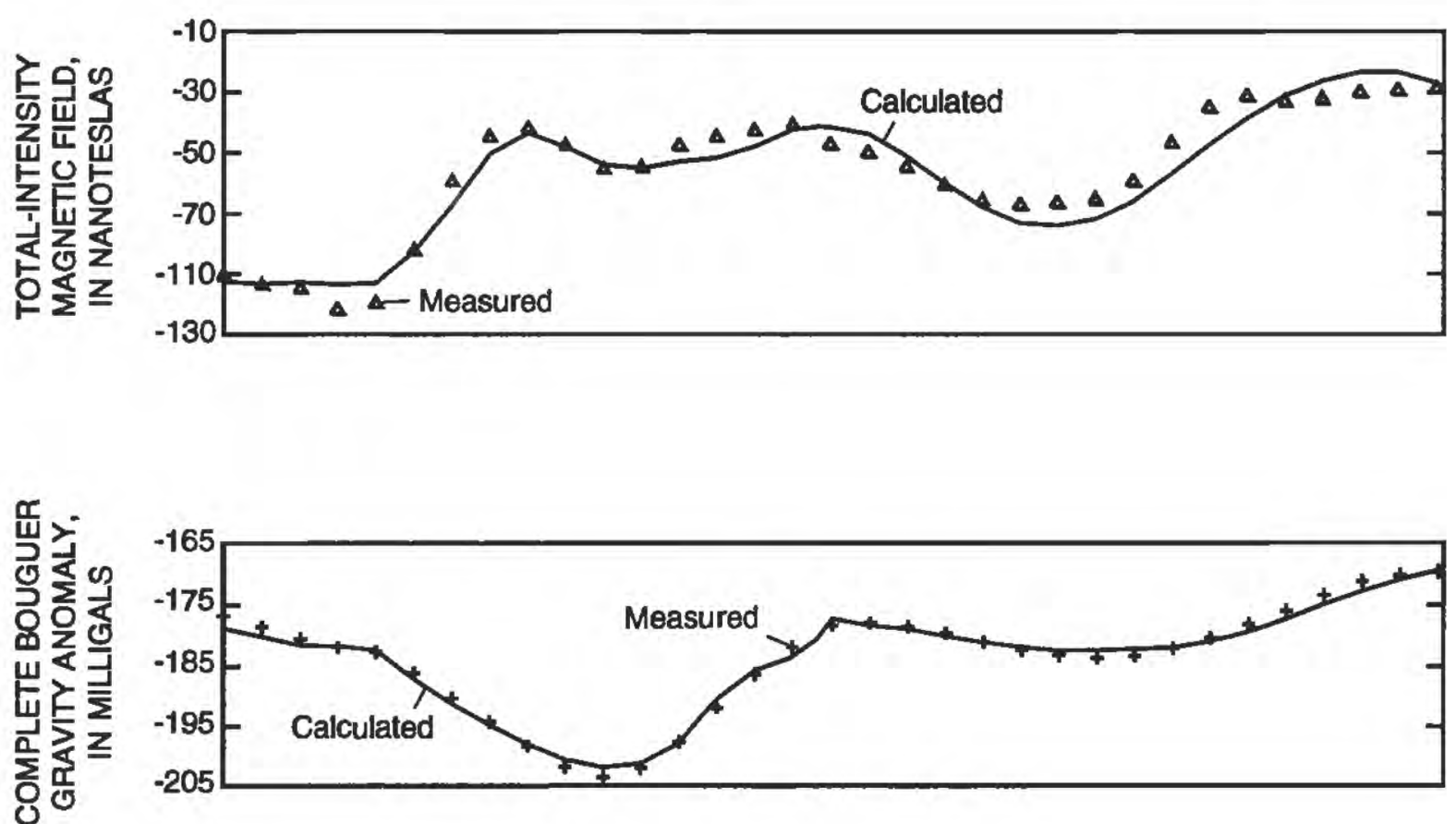

A

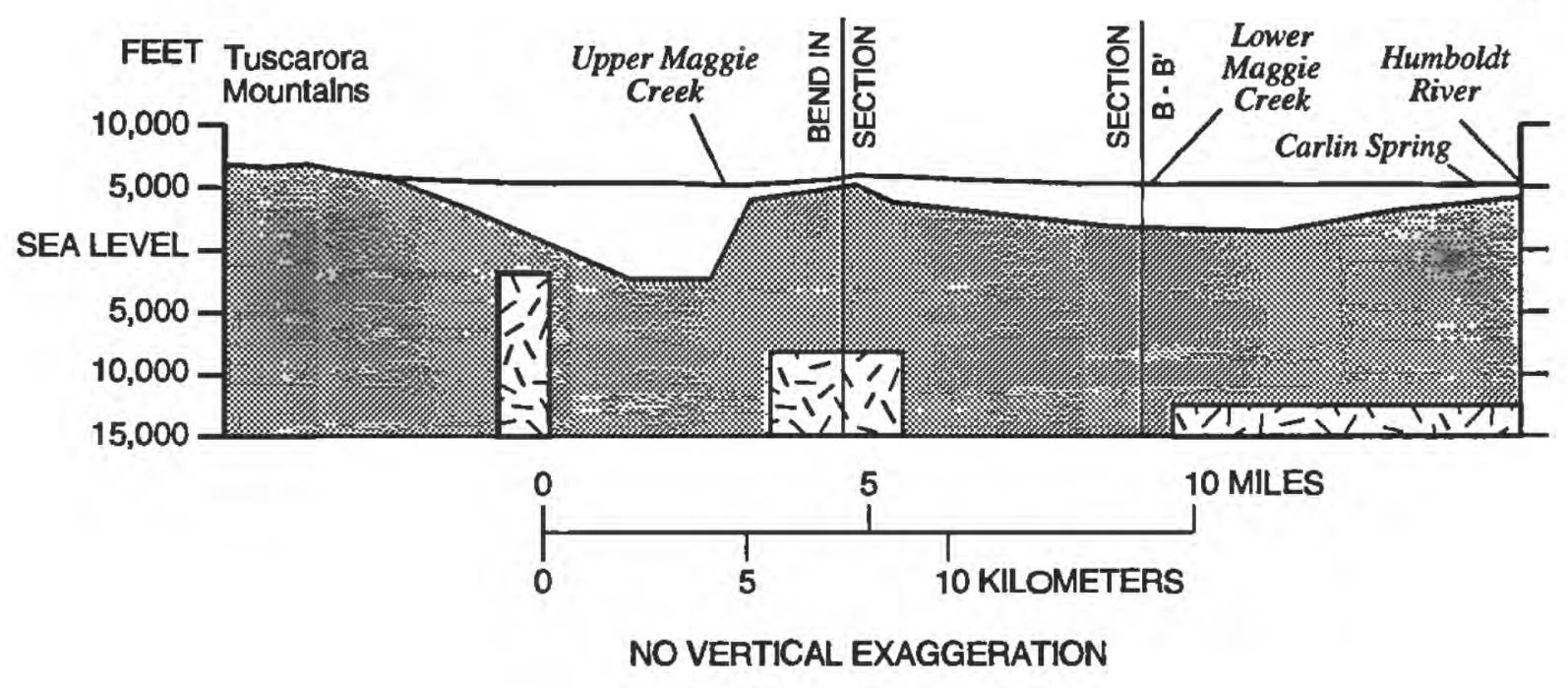

EXPLANATION

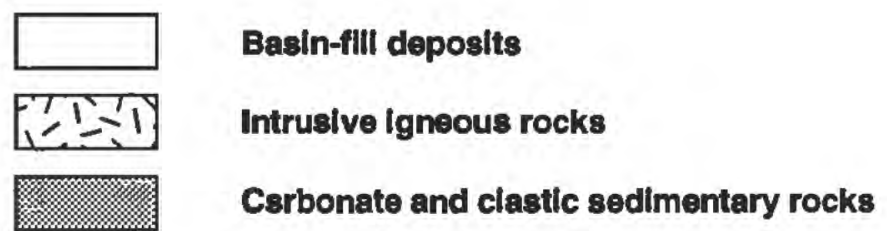

Figure 14. Generailzed geologic section $A-A^{\prime}$ and corresponding profiles of complete Bouguer gravity anomaly and magnetic intensity, in lower Maggie Creek area, northeastern Nevada. See figures 5, 12, and 13 for section location. 

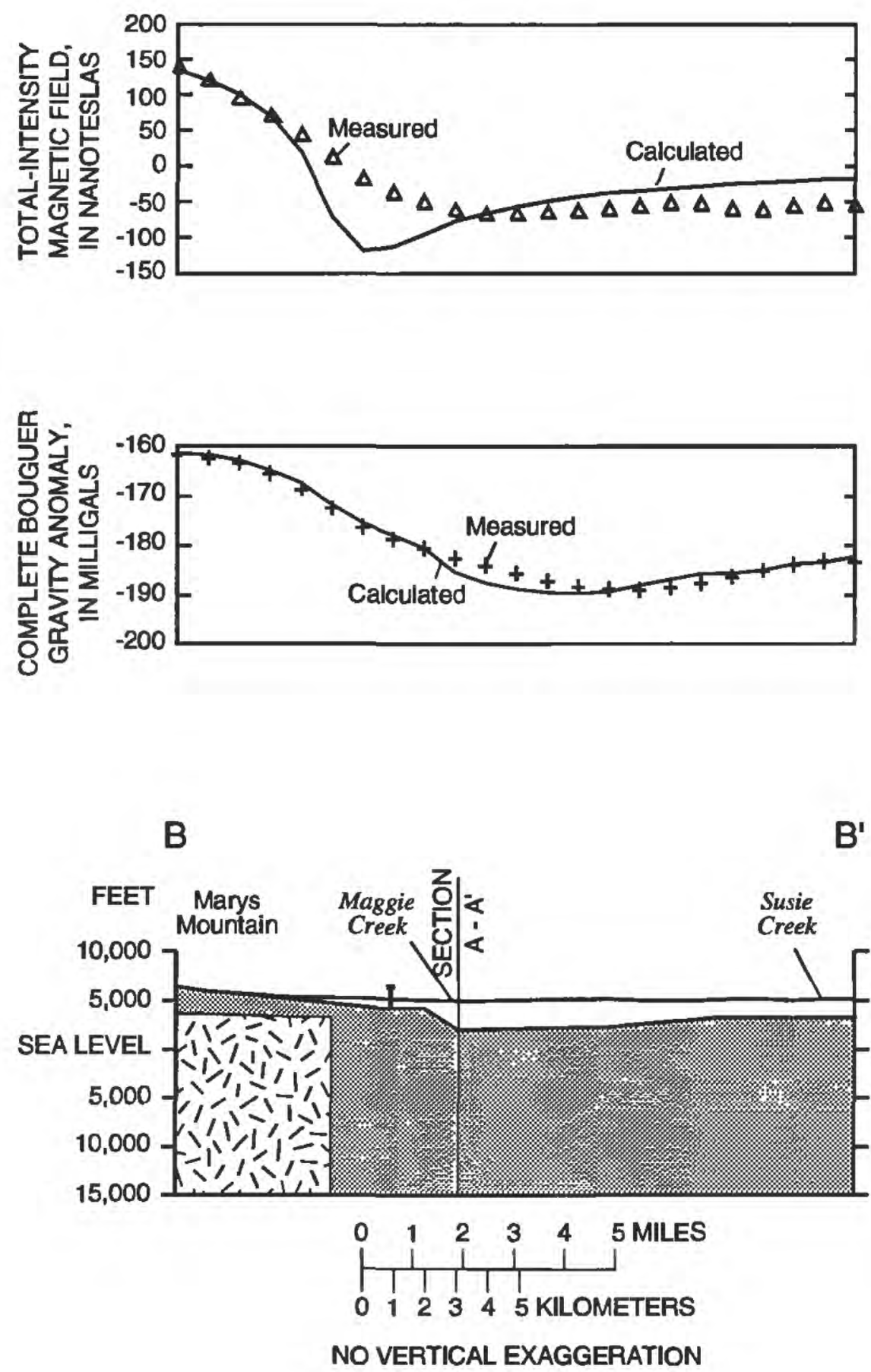

\section{EXPLANATION}

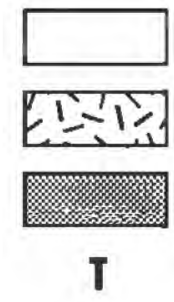

Basin-fill dsposits

intrusive Ignsous rocks

Carbonste snd clastlc sedlmsntary rocks

Wsll - Penetrates 840 feet of basin-fill deposits overlying bedrock

Figure 15. Generalized geologic section $B-B^{\prime}$ and corresponding profiles of complete Bouguer gravity anomaly and magnetic intensity in lower Maggie Creek area, northeastern Nevada. See figures 5,12 , and 13 for section location.
The geophysical models shown as sections in figures 14 and 15 represent the complex geology of the area as three simplified bodies: (1) Basin-fill deposits of the Carlin formation of Regnier (1960), alluvial fans, and stream flood plains; (2) bedrock consisting of carbonate and clastic sedimentary rocks; and (3) bedrock consisting of intrusive igneous rocks. Carbonate and clastic sedimentary rocks were combined as one unit because gravity and magnetic data were not sufficiently detailed to distinguish the two. In addition, the data were not sufficiently detailed to distinguish basin-fill deposits from interbedded shallow volcanic rocks in lower Maggie Creek Basin. Assumed values of density and magnetic susceptibility of the bodies are tabulated below:

\begin{tabular}{lcc}
\hline Hydrogeoiogic unit & $\begin{array}{c}\text { Density } \\
\text { (grams } \\
\text { per cubic } \\
\text { centimeter) }\end{array}$ & $\begin{array}{c}\text { Msgnetic } \\
\text { susceptibility } \\
\text { (dimensioniess) }\end{array}$ \\
\hline Basin-fill deposits & 2.12 & 0.0001 \\
Intrusive igneous rocks & 2.57 & .0012 \\
Carbonate and clastic & 2.47 & .00001 \\
$\quad$ sedimentary rocks & & \\
\hline
\end{tabular}

These values are within ranges of values published for similar rock types (Carmichael, 1989, p. 333-349; Olhoeft and Johnson, 1989, p. 161-173).

The structural basin underlying the topographic basin of upper Maggie Creek is bounded on the west by the Tuscarora Mountains structural block and on the east by the Schroeder Mountain uplift. The structural basin is asymmetric and its deepest parts underlie the east side of the topographic basin, where basin-fill deposits are as much as 7,000-8,000 ft thick (fig. 14).

The topographic basins of lower Maggie, Marys, and Susie Creeks are underlain by a broad, poorly defined structural basin. Proprietary gravity and aeromagnetic data suggest that the structural basin is complex and consists of several fault-bounded subbasins (T.V. Weis, oral commun., 1990). Between the Schroeder Mountain uplift and the Humboldt River, the structural basin contains basin-fill deposits as much as $4,000 \mathrm{ft}$ thick (fig. 14). The deposits are less than $1,000 \mathrm{ft}$ thick near Marys Mountain (fig. 15) and about $1,000 \mathrm{ft}$ thick beneath the Humboldt River flood plain (fig. 14). Thickness of basin fill is known at one site along section B-B', where a well penetrates $840 \mathrm{ft}$ of the deposits (fig. 15). 
Igneous rocks have intruded the carbonate and clastic sedimentary rocks beneath the west side of upper Maggie Creek Basin, the Schroeder Mountain uplift, and the west sides of lower Maggie and Marys Creek Basins (figs. 14 and 15). These bodies are believed to be parts of the extensive intrusive body that underlies Marys Mountain and the southern Tuscarora Mountains. Estimated depths to the bodies are about $7,000 \mathrm{ft}$ in the upper Maggie Creek Basin, more than $10,000 \mathrm{ft}$ at the Schroeder Mountain uplift, about 2,000 $\mathrm{ft}$ along the east side of Marys Mountain, and as much as $18,000 \mathrm{ft}$ in the lower Maggie Creek Basin.

Comparison of calculated and measured gravity and magnetic profiles suggest that sections $A-A^{\prime}$ and B-B' (figs. 14 and 15) are geologically reasonable. This is especially true for the calculated gravity profiles, which closely fit the corresponding measured profiles. The calculated and measured magnetic profiles also agree fairly well except for part of section B-B' along the east side of Marys Mountain and the west side of the adjacent structural basin (fig. 15). Several attempts were made to improve the fit of the calculated and measured magnetic profiles for section B-B'. These attempts involved changing the assumed geometry and magnetic susceptibility of the body of intrusive igneous rocks beneath Marys Mountain. However, changes in the geometry of the body diminished the fit of calculated to measured gravity profiles. Changes in the value for magnetic susceptibility diminished the overall fit of calculated to observed magnetic profiles. Reasons for the poor fit of calculated to measured magnetic profiles along section B-B' are not clear. Perhaps more detailed measurements of the gravity and magnetic fields in the area would make it possible to improve the fit. In addition, detailed field measurements of the density and magnetic susceptibility of all hydrogeologic units would reduce the uncertainty of both models.

\section{HYDROLOGIC SYSTEM}

\section{Surface Water}

The principal streams in the lower Maggie Creek area are Maggie, Marys, and Susie Creeks, all of which are tributary to the Humboldt River. A large part of total annual runoff for each stream comes from snowmelt, which can last from late winter through early summer. During this part of the year, flow characteris- tics of the four streams are similar. During other times of the year, flow characteristics of the streams differ because of differences in baseflow and the effects of evapotranspiration.

Baseflow of a stream is sustained by groundwater inflow, either directly into the stream channel or from nearby springs. Baseflow can vary from year to year or over shorter periods because different sources of ground water can dominate. The minimum baseflow, the amount of flow that will be sustained in the stream during dry years, is the long-term average discharge of the underlying aquifer into the stream channel. Higher values of baseflow in the study area are due to a combination of the minimum baseflow and the effects of short-term recharge from low-altitude snowmelt. The volume of the low-altitude snowpack can vary widely from year to year. In some years, none is available, and in others, April 1989 for instance, the low-altitude snowpack is substantial.

Streamflow measurements at sites along Maggie, Marys, and Susie Creeks and the Humboldt River were used to identify gaining and losing reaches of the streams, to quantify parts of water budgets, and to better understand relations of streams and aquifers. Streamflow-measurement sites in the lower Maggie Creek area are shown in figure 16.

The 12-month period from October 1 to September 30 is referred to as the water year. This period is used in this report for discussing annual and long-term flow characteristics of a stream. References to the calendar year in this report are accompanied either by the month or time of year (September 1990, or fall of 1990, for instance).

\section{Maggie Creek}

The earliest documented stage and streamflow measurements on Maggie Creek were made above the bridge at old Highway 40 (near site MC-8, fig. 16) during water years 1914-24. Maximum discharge during the snowmelt runoff ranged from $100 \mathrm{ft}^{3} / \mathrm{s}$ in some years to nearly $800 \mathrm{ft}^{3} / \mathrm{s}$ in water year 1922 (U.S. Geological Survey, 1960, p. 374). After the snowmelt runoff, the flow rapidly decreased each year, usually to less than $1 \mathrm{ft}^{3} / \mathrm{s}$. Total annual runoff ranged from a low of about 3,000 acre-ft in 1924 to a high of about 34,000 acre-ft in 1914 (U.S. Geological Survey, 1960, p. 374).

Average annual runoff at the mouth of Maggie Creek was 17,000 acre-ft/yr for the period 1914-24. This value is believed to be a reasonable estimate for 


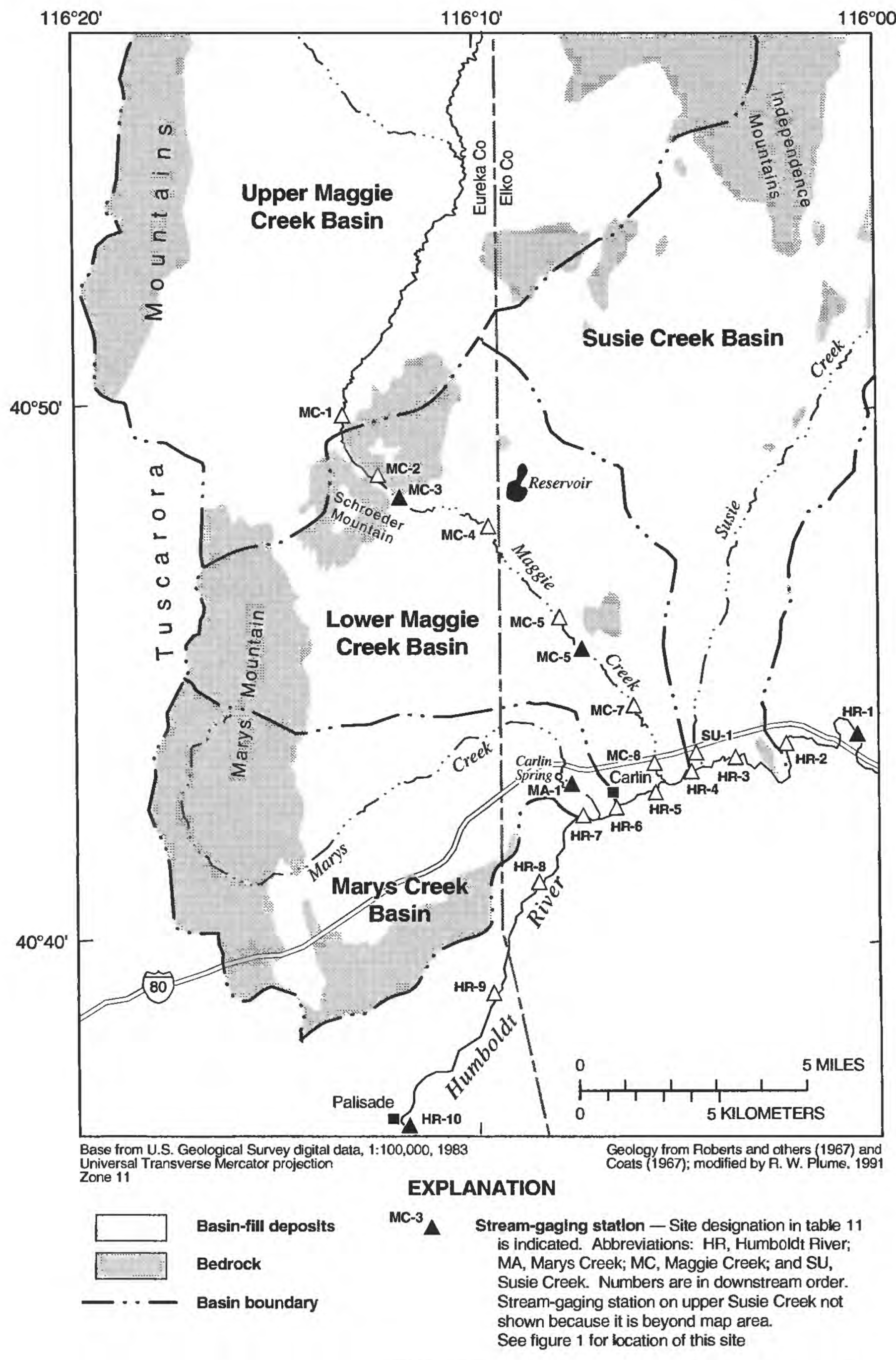

MC-1 $\triangle \quad$ Miscellaneous-measurement site - Site designation in table 11 is indicated. Abbreviations: HR, Humboldt River; MA, Marys Creek; MC, Maggie Creek; and

SU, Susie Creek. Numbers are in downstream order

Figure 16. Stream-gaging stations and miscellaneous streamflow-measurement sites in lower Maggie Creek area, northeastern Nevada. 
long-term, average annual runoff at the site for the following reason. Nearby at the stream gaging station on the Humboldt River at Palisade (site HR-10, fig. 16), the average annual runoff for 1914-24 was about 290,000 acre-ft/yr (from U.S. Geological Survey National Water Information System). The long-term (1903-91) average annual runoff at the gaging station also is about 290,000 acre-ft/yr (Garcia and others, 1992, p. 190). The 1914-24 and long-term averages for the Humboldt River at Palisade are about the same. This suggests that the average annual runoff for 191424 at the mouth of Maggie Creek provides a reasonable estimate of average runoff under natural or near natural, long-term conditions.

Near its mouth, Maggie Creek commonly was dry in the summer during the period 1914-24. This is illustrated by the flow-duration curve in figure 17, which shows the probability that flow of any magnitude will be equaled or exceeded. Flows of $1 \mathrm{ft}^{3} / \mathrm{s}$ were equaled or exceeded about 72 percent of the time. Thus, the flow was less than $1 \mathrm{ft}^{3} / \mathrm{s}$ about 30 percent of the time during 1914-24. The shape of the curve at low flows indicates that Maggie Creek near its mouth has little or no baseflow (R.P. Williams, U.S. Geological Survey, oral commun., 1990).

Streamflow measurements along Maggie Creek were made intermittently at eight sites (fig. 16) beginning in August 1988. Stream gaging stations were established at two of the sites (MC-3 and MC-6) to monitor streamflow along the reach of the stream next to the Gold Quarry mine. The gage at the upper site has been operating since September 1989 and the gage at the lower site since December 1989.

Streamflow characteristics of upper and lower Maggie Creek differ markedly. Upper Maggie Creek is a gaining reach of stream along the west side of the unnamed hills. Measured streamflow at site MC-1 has ranged from $1.6 \mathrm{ft}^{3} / \mathrm{s}$ on August 29,1988 , to $200 \mathrm{ft}^{3} / \mathrm{s}$ on April 13, 1989. Flow of the stream measured at the site during October and November, after evapotranspiration had begun to approach minimum rates, was 4.4 $\mathrm{ft}^{3} / \mathrm{s}$ on October 26,$1988 ; 5.2 \mathrm{ft}^{3} / \mathrm{s}$ on November 21 , $1988 ; 8.8 \mathrm{ft}^{3} / \mathrm{s}$ on November 14,1989 ; and $5.8 \mathrm{ft}^{3} / \mathrm{s}$ on October 24, 1991 (table 11). The lower values of streamflow measured during the fall $\left(4.4\right.$ and $5.2 \mathrm{ft}^{3} / \mathrm{s}$, table 11) are believed to be due to long-term groundwater discharge. The higher value of $8.8 \mathrm{ft}^{3} / \mathrm{s}$, measured during fall 1989 , is believed to be due to a

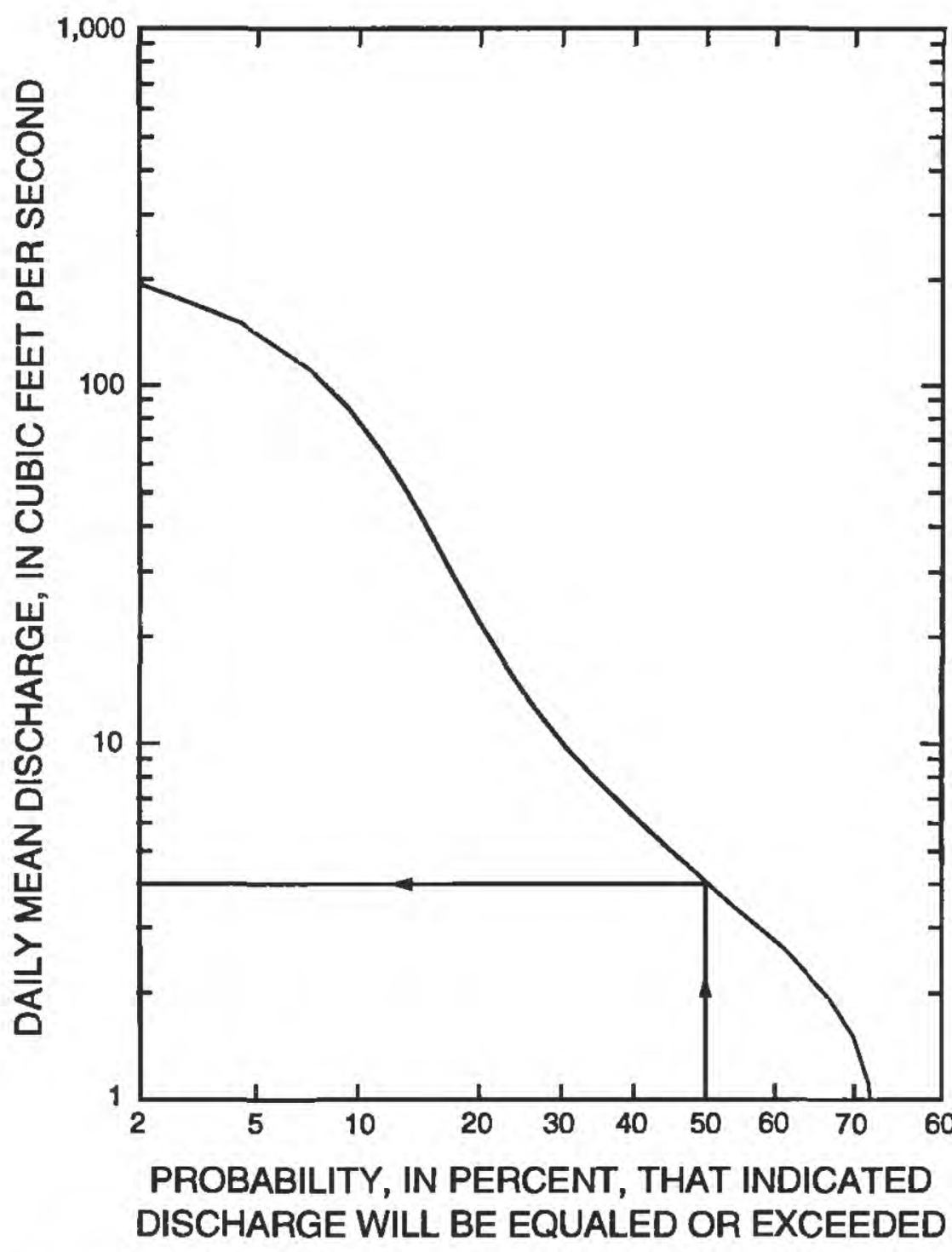

Figure 17. Frequency distribution of discharge of Maggie Creek, northeastern Nevada, near its mouth (site MC-8 in table 11 and figure 16), water years 1914-24 (data from Schroer and Moosbumer, 1978, p. 261). Example: A flow of 4 cubic feet per second was equaled or exceeded 50 percent of the time.

combination of the estimated minimum baseflow and the effects of the low-altitude snowmelt of the previous late winter and spring.

The reach of lower Maggie Creek southeast of Maggie Creek canyon consistently loses flow and is dry over much of the reach from mid-summer to late fall. The upper gaging station on Maggie Creek (site MC-3, fig. 16) is at the mouth of the Maggie Creek canyon. Total runoff of the stream at this site was about 8,100 acre-ft in the 1990 water year (Bostic and others, 1991, p. 166) and was 5,400 acre-ft in the 1991 water year (Garcia and others, 1992, p. 185). Flows ranged from as much as 50-60 $\mathrm{ft}^{3} / \mathrm{s}$ in late February 1990 (fig. 18A, and Bostic and others, 1991, p. 166) to no flow from July 23 to September 26, 1991 (Garcia and others, 1992, p. 185). This was the first time since the study began in August 1988 that a period of no flow 
was documented along this part of Maggie Creek. The extended drought and testing of dewatering wells at Gold Quarry mine are the most likely reasons for the period of no flow; however, the effect of each cannot be fully quantified until the drought ends.

The lower recording gage on Maggie Creek (site MC-6, fig. 16) was not activated until December 1, 1989 (fig. 18A). Estimated total flow for the 1990 water year is based on the following: (1) flow began at the station sometime in late October or early November 1989 and (2) total flow recorded during December 1989 was about 130 acre-ft (Bostic and others, 1991, p. 166). Assuming that November flows were less than December flows, total flow prior to activation of the gage probably did not exceed 100 acre-ft. Based on this assumption and the flow recorded at the station after activation (about 4,100 acre-ft; Bostic and others, 1991 , p. 167), total flow for the 1990 water year was an estimated 4,200 acre-ft. Total flow of Maggie Creek at the station in the 1991 water year was about 1,400 acreft (Garcia and others, 1992, p. 187). Streamflow losses were about 4,000 acre-ft/yr between the upper and lower gaging stations during both water years. Most of this streamflow loss entered underlying aquifers as recharge.

The upper Maggie Creek Basin is the contributing area for all streamflow at the upper gaging station and for most of the flow at the lower gaging station (sites MC-3 and MC-6, fig. 16). Streamflow gains and losses between the upper and lower stations from December 1989 through September 1991 are illustrated in figure $18 B$. This reach of the stream consistently lost flow during almost all of that period. The only exception was during late February and early March 1990 when the reach gained flow as a result of a low-altitude snowmelt. The greatest losses were about $15 \mathrm{ft}^{3} / \mathrm{s}$ during peak flows at the upper station in the snowmelt runoff of both years.

The infiltration capacity of the channel of Maggie Creek, between the upper gaging station and the site near its mouth (sites MC-3 and MC-8, fig. 16) to recharge the underlying aquifer can be estimated on the basis of comparisons of miscellaneous flow measurements at the two sites (table 11). When flows were about $12 \mathrm{ft}^{3} / \mathrm{s}$ or less at the upper site (MC-3), little of that flow reached the lower site. This suggests that streamflow losses can infiltrate the channel of lower Maggie Creek at a rate of $10-20 \mathrm{ft}^{3} / \mathrm{s}(7,000-14,000$ acre-ft/yr) if sufficient flow is available at the start of the reach. However, when the flow of Maggie Creek at
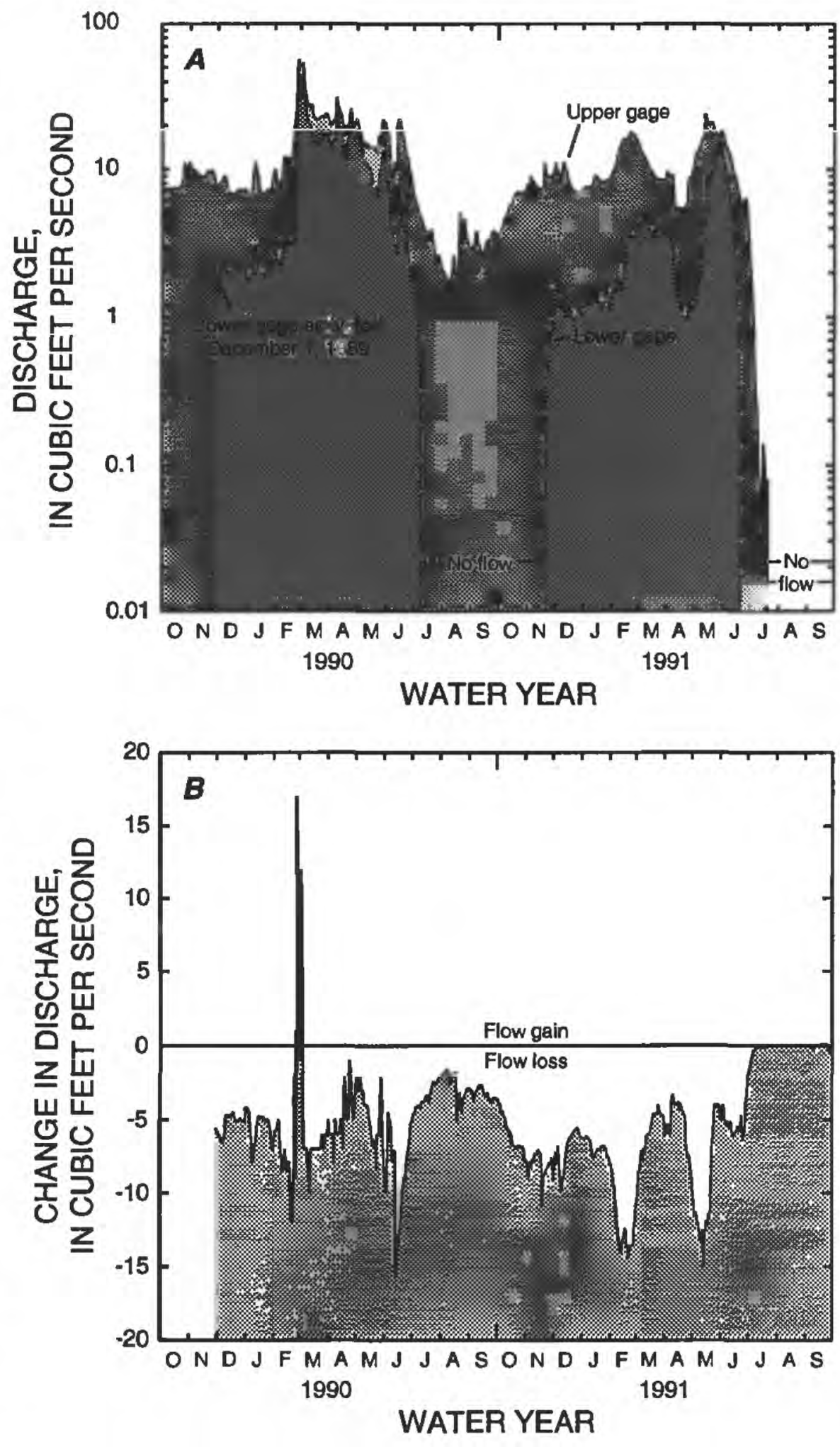

Figure 18. Flow characteristics of Maggie Creek, northeastern Nevada, water years 1990-91. A, Daily rnean discharge at upper and lower gaging stations (sites MC-3 and MC-6, respectively, in table 11 and figure 16); and $B$, Change in daily mean discharge between the two stations (computed as flow difference between lower and upper sites).

the upper site exceeds some threshold value, probably in the range from 10 to $20 \mathrm{ft}^{3} / \mathrm{s}$, virtually all of the additional flow will enter the Humboldt River as runoff. The smaller value $\left(10 \mathrm{ft}^{3} / \mathrm{s}, 7,000\right.$ acre-ft/yr) was used as a conservative estimate of ground-water recharge from infiltration of streamflow in the lower Maggie Creek Basin (see subsequent sections titled "Ground Water" and "Water Budgets"). 
The flow of Maggie Creek is diverted at several sites for irrigation of crops and meadows. Total diversions have not been measured; however, amounts that can be diverted each year, according to permits on file at the Nevada Division of Water Resources, are 3,487 acre-ft in the upper Maggie Creek Basin and 1,379 acre-ft in the lower basin (table 4).

\section{Marys Creek}

Marys Creek consists of two reaches, each having different flow characteristics. Streamflow in the reach upstream from Carlin spring is ephemeral; it flows only during the snowmelt runoff or in response to heavy precipitation. Otherwise, this reach of Marys Creek is a dry wash. Streamflow in the lower reach of Marys Creek, from Carlin spring to its mouth, is perennial as a result of the discharge of the spring. Since November
1989, the flow of Marys Creek has been measured at a continuously recording stream-gaging station below the spring (site MA-1; fig. 16).

Runoff due to snowmelt from the Marys Creek Basin during water years 1990 and 1991 began in late February and mid-March, respectively (fig. 19A). Peak flows were $20-24 \mathrm{ft}^{3} / \mathrm{s}$ and $11 \mathrm{ft}^{3} / \mathrm{s}$ during the two water years. The duration of the runoff during both years was short, lasting no more than about 2 weeks. During the rest of each year, the flow of Marys Creek at the gaging station represented the discharge of Carlin spring, minus the amount diverted from the spring for the town of Carlin. Daily mean flow sometimes was less than $1 \mathrm{ft}^{3} / \mathrm{s}$ during the summer of 1991 (fig. 19A).

Annual discharge of Carlin spring can be computed as total discharge measured at the Marys Creek gaging station plus the amount diverted for municipal

Table 4. Annual water use in study area, northeastern Nevada, 1985-90

[Values, rounded, in acre-feet per year; Abbreviations: --, not available; <, less than]

\begin{tabular}{|c|c|c|c|c|c|c|}
\hline \multirow[b]{2}{*}{ Use } & \multicolumn{6}{|c|}{ Calendar year } \\
\hline & 1985 & 1986 & 1987 & 1988 & 1989 & 1990 \\
\hline \multicolumn{7}{|c|}{ Surface Water } \\
\hline $\begin{array}{l}\text { Agriculture } \\
\text { Maggie Creek }^{2} \\
\text { Marys Creek }^{3} \\
\text { Municipal }^{4}\end{array}$ & $\begin{array}{r}<4,900 \\
<630 \\
--\end{array}$ & $\begin{array}{r}<4,900 \\
<630 \\
--\end{array}$ & $\begin{array}{r}<4,900 \\
<630 \\
750\end{array}$ & $\begin{array}{r}<4,900 \\
<630 \\
730\end{array}$ & $\begin{array}{r}<4,900 \\
<630 \\
800\end{array}$ & $\begin{array}{r}<4,900 \\
<630 \\
600\end{array}$ \\
\hline \multicolumn{7}{|c|}{ Ground water } \\
\hline $\begin{array}{l}\text { Agriculture }^{5} \\
\text { Mìning }^{6} \\
\text { Municipal }^{7}\end{array}$ & $\begin{array}{r}<1,800 \\
790 \\
0\end{array}$ & $\begin{array}{r}<1,800 \\
1,700 \\
0\end{array}$ & $\begin{array}{r}<1,800 \\
2,600 \\
0\end{array}$ & $\begin{array}{r}<1,800 \\
3,600 \\
0\end{array}$ & $\begin{array}{r}<1,800 \\
7,100 \\
0.2\end{array}$ & $\begin{array}{r}<1,800 \\
6,000 \\
3\end{array}$ \\
\hline \multicolumn{7}{|c|}{$\begin{array}{l}{ }^{2} \text { Permitted annual diversions are 3,487 acre-feet from upper Maggie Creek and 1,379 acre- } \\
\text { feet from lower Maggie Creek, for total of less than 4,900 acre-feet per year. } \\
{ }^{3} \text { Permitted annual diversion is } 629 \text { acre-feet. Diversion point is downstream from Marys }\end{array}$} \\
\hline \multicolumn{7}{|l|}{ Creek gaging station. } \\
\hline \multicolumn{7}{|c|}{$\begin{array}{l}{ }^{4} \text { Diversion from Carlin spring above } 1 \\
\text { Carlin City Clerk, written commun., } 1992 .\end{array}$} \\
\hline \multicolumn{7}{|c|}{$\begin{array}{l}{ }^{5} \text { Two irrigation wells in lower Maggie Creek Basin (wells } 25 \text { and 26, table 13). Permits } \\
\text { allow pumpage of } 1,782 \text { acre-feet per year. Data from Nevada Division of Water Resources, } \\
\text { Carson City, Nev. }\end{array}$} \\
\hline \multicolumn{7}{|c|}{$\begin{array}{l}{ }^{6} \text { All pumpage from lower Maggie Creek Basin. Data for } 1985-89 \text { from Newmont Gold } \\
\text { Co., Carlin, Nev. Data for } 1990 \text { from Nevada Division of Water Planning, } 1990 \text { Water Use } \\
\text { Survey-Mining Database for } 1990 \text {. }\end{array}$} \\
\hline${ }^{7}$ Munic & ower Ma & ie Cree & $\sin (w e$ & 5, table & & \\
\hline
\end{tabular}



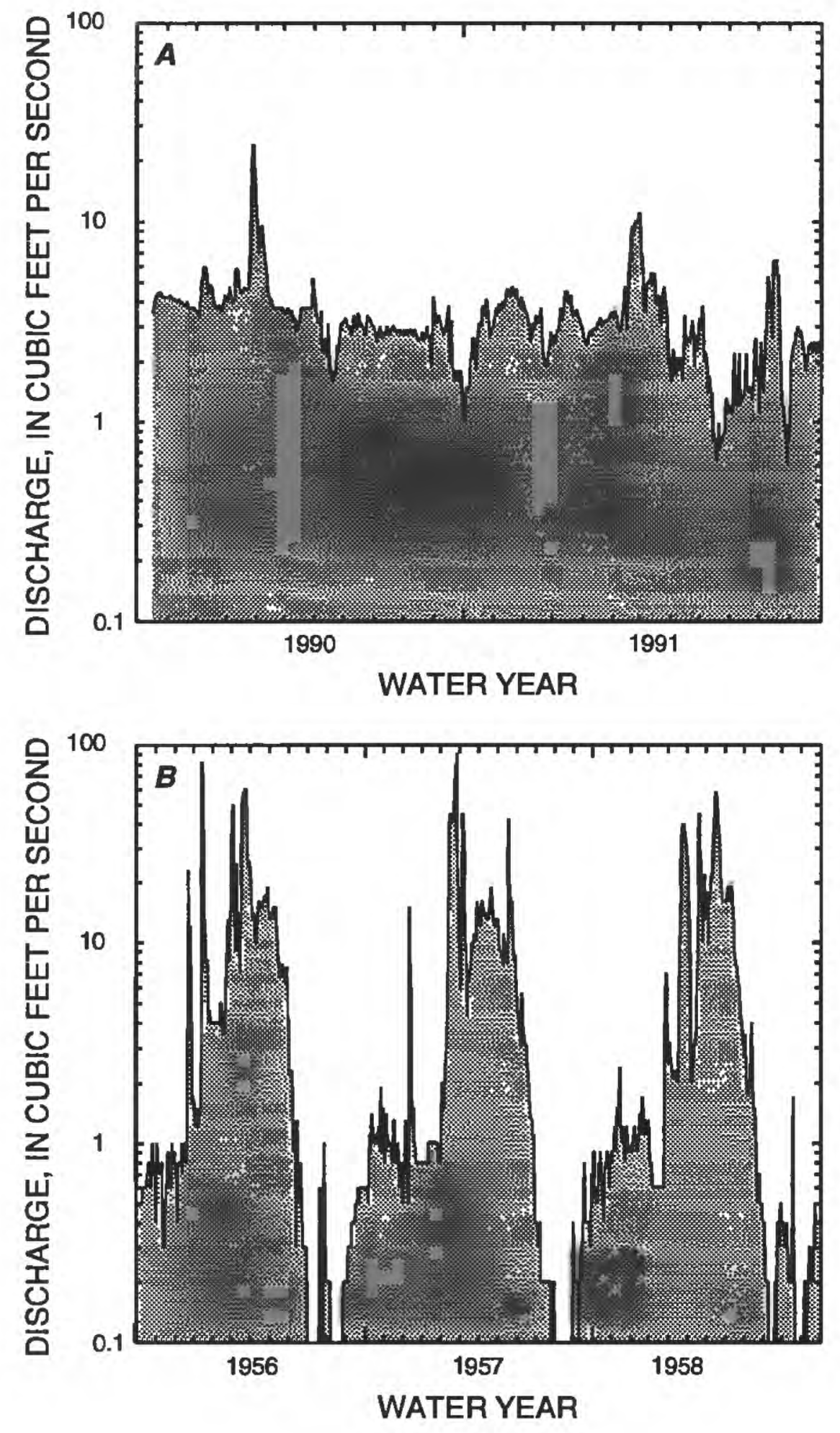

Figure 19. Daily mean discharge of (A) Marys Creek at Carlin, water years 1990-91 (site MA-1 in figure 16) and (B) Susie Creek near Carlin, water years 1956-58 (see figure 1 for location of site).

use by Carlin, minus the estimated volume of the snowmelt runoff from the basin above the spring. The total volume of flow measured at the gaging station during the first water year of operation (Nov. 18, 1989Sept. 30, 1990) was about 2,400 acre-ft (Bostic and others, 1991, p. 168). During the same period, the municipal diversion was an estimated 600 acre-ft (C.L Aiazi, Carlin City Clerk, written commun., 1992). The snowmelt runoff appears to have begun on
February 25 and to have ended 16 days later on March 12,1990 (Bostic and others, 1991, p. 168). The volume of the runoff was computed as total volume of flow during the 16-day period ( 350 acre-ft) minus an estimated spring discharge of 130 acre- $\mathrm{ft}^{(}\left(4 \mathrm{ft}^{3} / \mathrm{s}\right)$. Thus, the volume of the runoff was an estimated 220 acre-ft. Total flow from Carlin spring during the part of the water year that the gaging station was operated was an estimated 2,800 acre-ft. The average flow was about $3.9 \mathrm{ft}^{3} / \mathrm{s}$.

During the 1991 water year, the total volume of flow measured at the Marys Creek gaging station was about 2,200 acre-ft (Garcia and others, 1992, p. 188), and the municipal diversion was an estimated 640 acre-ft (C.L. Aiazi, written commun., 1992). The snowmelt runoff appears to have begun on March 18 and ended 16 days later on April 2, 1991 (Garcia and others, 1992, p. 188). The total volume of flow during the 16-day period was 260 acre-ft and the discharge of the spring was an estimated 130 acre- $\mathrm{ft}\left(4 \mathrm{ft}^{3} / \mathrm{s}\right)$. Thus, the volume of the snowmelt runoff was an estimated 130 acre-ft. Total volume of discharge from Carlin spring during water year 1991 was about 2,700 acre- $\mathrm{ft}$, for an average flow of $3.7 \mathrm{ft}^{3} / \mathrm{s}$.

The values of average flow of Carlin spring for water years 1990-91 may represent long-term average flow of the spring. However, the total volume of flow will have to be determined for additional water years, especially those in which precipitation is normal, before a reliable value of average long-term flow can be determined. A value of $4 \mathrm{ft}^{3} / \mathrm{s}(3,000 \mathrm{acre}-\mathrm{ft} / \mathrm{yr})$ is used for making water-budget calculations in subsequent sections of this report.

In addition to the municipal diversion at Carlin spring, streamflow of Marys Creek is diverted below the stream gaging station for irrigation of crops and meadows. Amounts diverted for municipal use were $750,730,800$, and 600 acre-ft, respectively, for the years 1987 to 1990 (table 4). The amount that may be diverted for agricultural use is $629 \mathrm{acre}-\mathrm{ft} / \mathrm{yr}$, according to permits on file at the Nevada Division of Water Resources.

\section{Susie Creek}

The flow of Susie Creek was measured continuously during water years $1956-58$ at a gaging station $15 \mathrm{mi}$ upstream from its mouth near the confluence of Adobe Creek (site, shown in fig. 1, is beyond map area of fig. 16). During all 3 years, periods of runoff in early 
to mid-winter were of short duration (fig. 19B). These runoff periods could have been the result of intense winter rainfall or the melting of low-altitude snowpack. The snowmelt runoff each year was of longer duration. After the snowmelt, the flow of the stream rapidly declined to a summer flow, which was consistently less than $1 \mathrm{ft}^{3} / \mathrm{s}$. Total annual flow at the gaging station during the 3 years was about $4,600,4,400$, and 4,300 acreft, respectively (U.S. Geological Survey, 1963, p. 250). Average long-term flow at the site is an estimated 4,000-5,000 acre-ft/yr.

Streamflow of Susie Creek was measured during the present study at the Highway 40 bridge (site SU-1 in table 11 and fig. 16). Measured flows at the site during late fall were $0.98 \mathrm{ft}^{3} / \mathrm{s}$ on November 21, 1988; $3.2 \mathrm{ft}^{3} / \mathrm{s}$ on November 13,1989; and $0.36 \mathrm{ft}^{3} / \mathrm{s}$ on October 24, 1991. These differences in baseflow from year to year are the result of variations in the effects of low-altitude snowmelt during the previous spring. The low-altitude snowmelt in spring 1989 may have produced recharge along the lowlands near Susie Creek sufficient to maintain relatively high baseflow 9 months later. In contrast, baseflows in the fall of 1988 and 1991 may have been less because little lowaltitude snow was available as a source of local, shortterm recharge in those years.

\section{Humboldt River}

The Humboldt River forms the southern boundary of the lower Maggie Creek area. The flow of this reach of the river has been measured continuously since water year 1944 at streamflow gaging stations near Carlin and at Palisade (sites HR-1 and HR-10, respectively, fig. 16). Total annual runoff and groundwater discharge from the combined three basins of the study area can be estimated from the records for the two gaging stations.

Basins tributary to the reach of the Humboldt River between the two gaging stations are those of Maggie, Marys, and Susie Creeks, Dry Susie Creek east of the study area, and Woodruff Creek south of the river. The latter two basins are small and constitute only about 5 percent of the combined area of the five basins. Perhaps even more importantly, neither basin has areas of high altitude comparable to the three basins of the study area. Consequently, the reach of the river between the two gaging stations gains flow as runoff and ground-water discharge to the river channel mostly from the basins of the study area. These three basins constitute about 95 percent of the area tributary to this reach of the river.

Flow of the Humboldt River near Carlin during water years 1982-91 (fig. 20) includes some of the highest (1984) and some of the lowest (summers of 1987-91) flows measured in the 48-year period of record. The flow of the river during the snowmelt runoff differs from year to year according to the condition of the high-altitude snowpack in the mountain ranges of northeastern Nevada. After the snowmelt, the flow of the river rapidly decreases to the summer low flow. Early in the fall of each year, evapotranspiration declines to minimum rates. As a result, flow of the river increases to a baseflow that represents the combined effects of long-term ground-water discharge and, in some years, local recharge from low-altitude snowmelt during the previous spring.

Annual gains of the river between the Carlin and Palisade gaging stations have ranged from a low of 5,000 acre-ft in 1961 to a high of about 160,000 acre-ft in 1983 (fig. 21A). The average annual gain was about 38,000 acre- $\mathrm{ft}$. These gains represent runoff from the study area due to the spring snowmelt, intermittent intense storms, discharge from Carlin spring and other unnamed springs nearby (sites 103, 106, and 107; table 12), as well as ground-water discharge into the river channel.

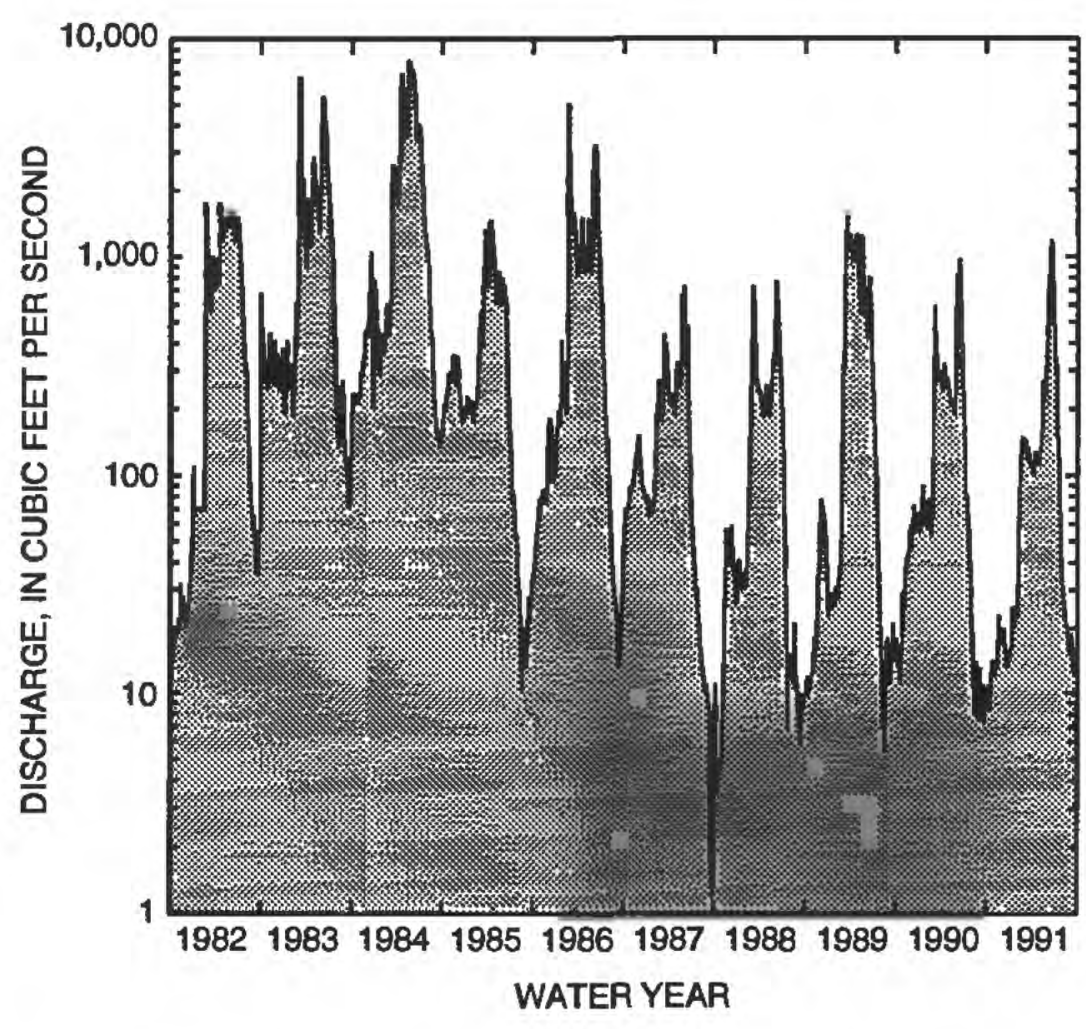

Figure 20. Daily mean discharge of Humboldt River near Carlin, northeastern Nevada, water years 1982-91 (site HR-1 in figure 16). 

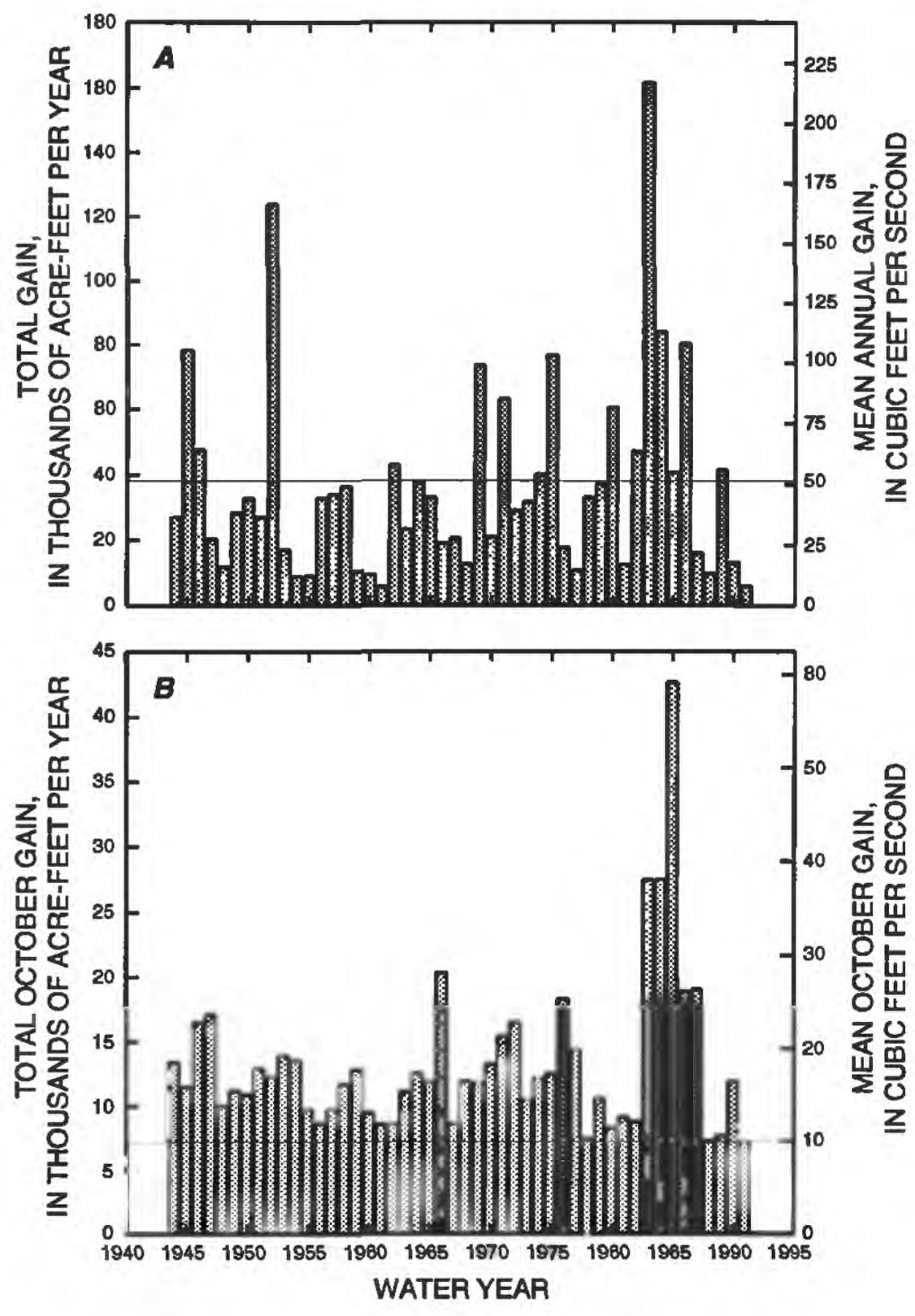

Figure 21. Streamflow gains of Humboldt River in the reach between Carlin and Palisade gaging stations, northeastern Nevada, (sites HR-1 and HR-10; figure 16), water years 1944-91. (A) Annual gain; horizontal line is combined mean annual runoff and ground-water discharge from three basins of study area. (B) October gain; horizontal line is gain due to long-term ground-water discharge from three basins of study area.

The annual gain in flow of the Humboldt River due to ground-water discharge from the lower Maggie Creek area can be estimated by comparing mean October flows at the Carlin and Palisade gaging stations (fig. $21 B$ ). October was selected as the best period for making this comparison because evapotranspiration, ice, and early winter storms usually do not affect baseflow. Mean gains in October flow of the river from 1944 to 1991 were as little as $10-12 \mathrm{ft}^{3} / \mathrm{s}$ during some years to nearly $60 \mathrm{ft}^{3} / \mathrm{s}$ in 1985 (fig. $21 B$ ). Variations in mean October flow are believed to be due to the amount of local recharge from low-altitude snowmelt during the previous spring and possibly to releases from bank storage.
Water years 1983 and 1984 were both exceptional for the high flows of the Humboldt River during the snowmelt runoff (fig. 20) and also for the combined runoff from Maggie, Marys, and Susie Creek Basins (fig. 21A). As a result, gains in mean October flows for 1983 and 1984 between the Carlin and Palisade gaging stations were among the largest for the period of record. However, the largest gain by far was in October 1985 , following a year of normal runoff. The large gain over this reach of the river in 1985 may be the result of 2 years of recharge from low-altitude snowmelt in the springs of 1983 and 1984.

The smaller gains in mean October flows are believed to be due only to average ground-water discharge from the Maggie, Marys, and Susie Creek Basins and from watersheds south of the river. Since water year 1944, gains in mean October flows have never been less than about $10 \mathrm{ft}^{3} / \mathrm{s}$ (fig. $21 B$ ). This minimum value for mean October gain of the river between the Carlin and Palisade gaging stations is due mostly to ground-water discharge from the study area and is used as a part of the water budget for the area (see section titled "Ground Water"). Ground-water discharge from the small watersheds south of the river is probably minimal.

Streamflow of the Humboldt River was measured intermittently at ten sites in the fall of 1988,1989 , and 1991 (table 11). Measured flows above Carlin (sites HR-2 and HR-3; table 11) and above Palisade (sites HR-8 and HR-9; table 11) show that this reach of the river was gaining flow. Gains were $17 \mathrm{ft}^{3} / \mathrm{s}$ on November 21,$1988 ; 10 \mathrm{ft}^{3} / \mathrm{s}$ on November $13-14,1989$; and $9 \mathrm{ft}^{3} / \mathrm{s}$ on October 22, 1991. The gain of $17 \mathrm{ft}^{3} / \mathrm{s}$ was affected by melting snow and does not represent baseflow. The other two gains, however, were not affected by recent storms or ice, and are further evidence that baseflow of this reach of the river is sustained by about $10 \mathrm{ft}^{3} / \mathrm{s}$ of ground-water discharge to the river channel.

\section{Ground Water}

Water levels in wells and mining exploration holes were used to define the shallow potentiometric surface (fig. 22) and to document water-level changes in the lower Maggie Creek area. Hole depths range from 10 to $15 \mathrm{ft}$ at shallow wells along lower Maggie Creek to $800-900 \mathrm{ft}$ at some of the deeper wells. Most of the wells are open to a single hydrogeologic unit where water was first found during drilling. The water-level contours in figure 22 generally are believed to represent the water table in the lower Maggie Creek area. 

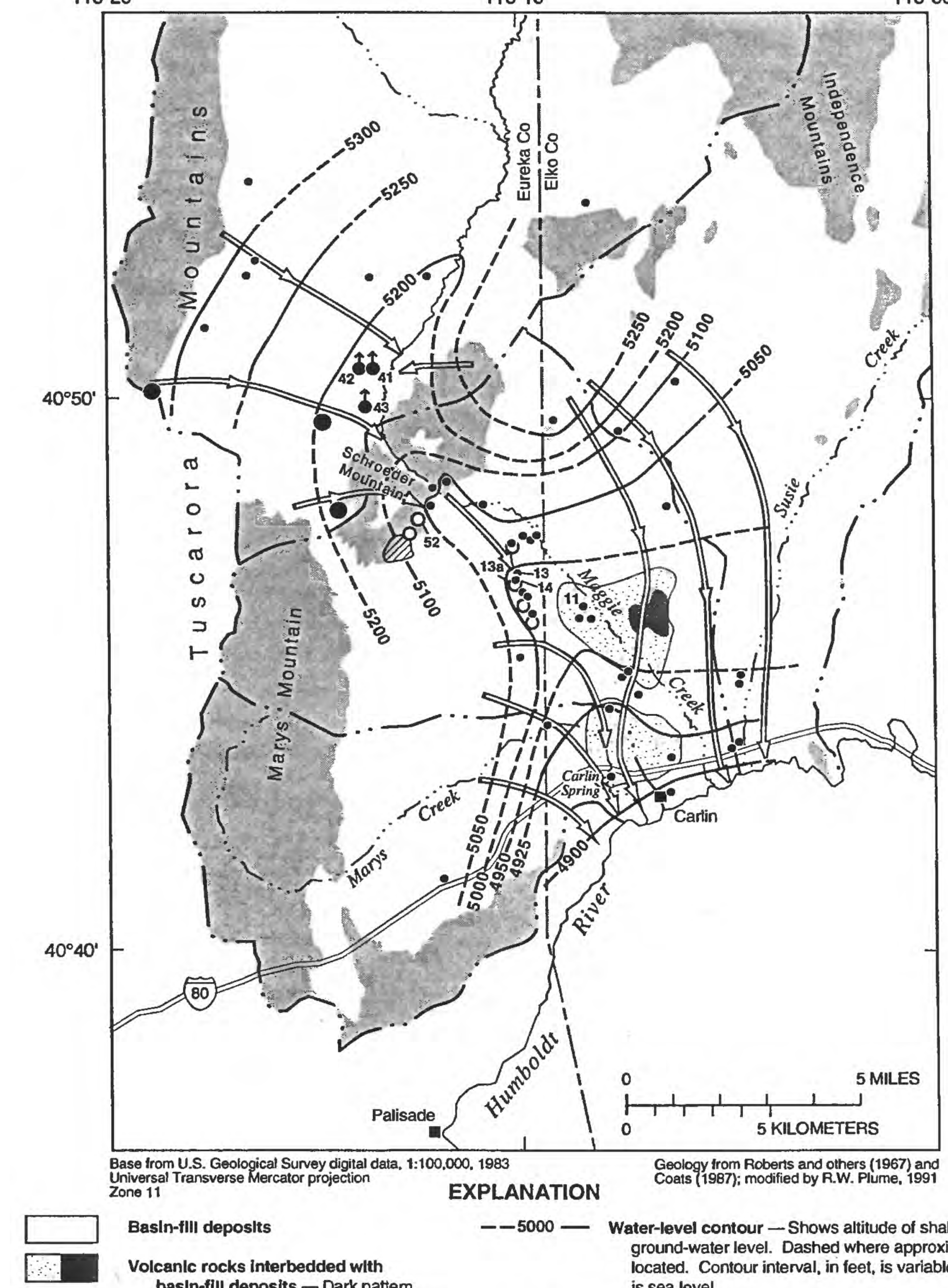

\section{Basin-flll deposits}

Volcanlc rocks interbedded with basin-fill deposits - Dark pattem shows mapped extent. Stippled pattern shows extent in subsurfaca based on interpretation of proprietary aeromagnetic data (T.V. Weis, Newmont Exploration Limited, written commun., 1990)

\section{Bedrock}

Gold quarry mine - Extent of pit as of 1993

BasIn boundary

Direction of shaliow ground-water flow Approximately located
- -5000 - Water-level contour - Shows altitude of shallow ground-water level. Dashed where approximately located. Contour interval, in feet, is variable. Datum is sea level

11. Observation well - Used for constructing contours. Penetrates basin-fill aquifer and, in places, interbedded volcanic rocks. Site number in table 13 is indicated

Observation well - Used for constructing contours. Penetrates carbonate and clastic sedimentary rocks

$43 f$ Flowing well - Heads measured at well not used for constructing contours because well penetrates deeper parts of basin-fill aquifer. Site number In table 13 is indicated

${ }^{13 a}$ P Production well for mining and milling - Water-level measurements not available. Site number in table 13 is indicated

Figure 22. Altitude of shallow ground-water levels in lower Maggie Creek area, northeastern Nevada, September 1990. 
Ground water in the upper Maggie Creek Basin flows southeast from recharge areas in the Tuscarora Mountains and westward from the recharge areas in the unnamed hills northeast of the Maggie Creek canyon (fig. 22). A broad ground-water divide coincides with the topographic divide of the unnamed hills.

Southwest of the Maggie Creek canyon, ground water flows from upper Maggie Creek Basin, through Schroeder Mountain, to lower Maggie Creek Basin (fig. 22). The recharge area for this ground water is in the southern Tuscarora Mountains at the extreme southern end of the upper Maggie Creek Basin.

Ground water flows upward in the vicinity of the Maggie Creek flood plain north of Schroeder Mountain. Heads measured at three flowing wells (sites 41 , 42, and 43; table 13 and fig. 22) are 4-9 ft above land surface. In addition, two of the wells are adjacent to each other and extend to depths of 120 and $575 \mathrm{ft}$, respectively. The head in the deep well was $0.6 \mathrm{ft}$ above the head in the shallow well in March 1989. (Water levels at these wells were not used to construct contours, because the heads may not represent shallow conditions.)

The net effect of the Schroeder Mountain uplift (Schroeder Mountain southwest of the Maggie Creek canyon and the unnamed hills northeast of the canyon) seems to be that it partly impedes ground-water movement between the upper and lower Maggie Creek Basins. This conclusion is based on the following evidence. First, water-level contours and ground-water flow lines indicate that ground water moves away from the topographic divide of the unnamed hills (fig. 22). Second, heads at the three flowing wells, which are completed to different depths, indicate an upward gradient for ground-water flow in the area adjacent to the west side of the unnamed hills. The heads indicate that an upward gradient extends from depths of at least $1,000 \mathrm{ft}$ to as shallow as $160 \mathrm{ft}$. Third, the minimum baseflow of Maggie Creek adjacent to the west side of the unnamed hills is an estimated $5 \mathrm{ft}^{3} / \mathrm{s}$. This baseflow is thought to be sustained by ground-water discharge to the stream channel resulting from the upward movement of ground water. Water-level contours and ground-water flow lines indicate that bedrock of the unnamed hills functions as a barrier to ground-water flow between the upper and lower Maggie Creek Basins. In contrast, contours and flow lines indicate that ground water flows from southern parts of the upper Maggie Creek Basin through permeable bedrock of Schroeder Mountain to the lower basin.
In the lower Maggie Creek Basin and adjacent parts of Marys and Susie Creek Basins, ground water flows toward production wells near Gold Quarry mine and toward discharge areas at Carlin spring and along the Humboldt River (fig. 22). The ground water flows east and southeast from recharge areas on Marys Mountain, southeast from Schroeder Mountain, and south from the unnamed hills northeast of Maggie Creek canyon. Topographic divides between the three basins do not function as ground-water divides.

A trough in the potentiometric surface extends northward from Carlin spring near the Humboldt River toward Maggie Creek and then northwestward to Schroeder Mountain (fig. 22). This appears to be a single feature; however, hydrologic evidence suggests that the trough is the result of two unrelated phenomena. The northwest-trending part of the trough is the result of pumpage from production wells at Gold Quarry mine (fig. 22).

The 5,000-ft contour defines this part of the trough where four production wells pump from basinfill deposits (fig. 22). The 5,050-ft contour also defines the trough farther west along the southeast side of Schroeder Mountain where two production wells pump from carbonate rocks. The shape of these two contours probably would be similar to the 4,925- and 4,950-ft contours if water levels had not declined as a result of the pumping.

The southern part of the trough is broader and partly coincides with shallow volcanic rocks interbedded with basin-fill deposits (see section titled "Hydrogeologic Units"). Horizontal gradients are relatively steep southeast of the unnamed hills and west of Marys Mountain. However, gradients are not nearly as steep in areas underlain by volcanic rocks. This flattening of the gradient, the broader trough in the potentiometric surface, and the convergence of ground-water flow lines towards Carlin spring (fig. 22) all indicate that the volcanic rocks function as a permeable drain for ground-water flow. Ground-water flow lines also indicate that pumping at Gold Quarry mine is intercepting ground water that otherwise would be flowing to Carlin spring (fig. 22).

Streamflow data presented previously in this report indicate that the reach of Maggie Creek in the lower basin loses flow and is dry during the summer and early fall. When this reach of the stream is dry, an unsaturated zone as deep as 30-40 ft develops between the stream channel and the underlying aquifer. During periods of streamflow, especially during snowmelt 
runoff, ground water is recharged by infiltration of streamflow, which creates a saturated zone that connects the stream channel with the underlying aquifer. When flow ceases, however, this mound of recharge under the channel gradually subsides until the next period of streamflow provides another pulse of recharge.

Water levels measured at well 11 (fig. 22 and table 13) during the study provide some of the best evidence for the effects of recharge from Maggie Creek on water levels in the lower basin. This well is about 200 $\mathrm{ft}$ southwest of the stream channel of Maggie Creek. Water levels were measured at this well from October 1988 to November 1991. During this period, some of the shallowest water levels (20-28 ft below land surface) were measured in the spring, when runoff was providing recharge to the aquifer. In contrast, the deepest water levels during that period $(26-61 \mathrm{ft})$ were measured in the fall, after unusually dry winters. The shallowest water level ever measured at well 11 (less than $7 \mathrm{ft}$ below land surface) was on April 30, 1982 (table 13). Total runoff of the Humboldt River at the Carlin gaging station was well above the average during that year (Frisbie and others, 1983, p. 158). Correspondingly high flows of Maggie Creek may have produced sufficient recharge to cause such shallow depth to water at the well.

\section{Recharge}

Ground-water recharge in the Maggie, Marys, and Susie Creek Basins comes from infiltration of rain and snowmelt and from infiltration of streamflow, most notably along lower Maggie Creek. Hydrologic evidence indicates that underflow of ground water from basins adjacent to the study area is negligible.

The method used to make estimates of groundwater recharge by infiltration of precipitation in the Great Basin is empirical. The method is based on estimated precipitation at different altitudes and on the assumption that only a fraction of total precipitation at a given altitude eventually infiltrates below the soil zone to become recharge ${ }^{f}$. The method was first developed and used in southern Nevada (Maxey and Jameson, 1948, p. 107-109). The approach was to

\footnotetext{
¥This method of estimating recharge includes (1) infiltration of precipitation and (2) infiltration of streamflow near mountain fronts. However, infiltration of streamflow along main stream channels in basin lowlands is not included, and is a separate recharge source.
}

estimate total annual precipitation for altitude zones above $6,000 \mathrm{ft}$, because recharge was believed to be negligible below that altitude. Ground-water recharge was then estimated as a percentage of the total precipitation for each zone.

The approach used for the present study was to develop a relation between annual precipitation and altitude for northeastern Nevada (fig. 4). This relation was used to estimate average annual precipitation for the midpoint of each 1,000-ft increment of altitude in the study area. Estimated potential recharge for each altitude zone was computed as the product of estimated annual precipitation for the zone, estimated percentage of precipitation becoming recharge, and the area of the zone in each basin (table 5). Values listed in table 5 are referred to as potential recharge because part may not infiltrate downward; instead, it may leave the basin as runoff (Rush and Everett, 1966, p. 26-27). Recharge estimates for areas below an altitude of $6,000 \mathrm{ft}$ were made because results of a recent study (Stone, 1992) indicate that as much as 2 percent of total precipitation below this altitude may become recharge.

Several uncertainties are inherent to this method of estimating recharge. First, the method is based on widely spaced precipitation data representing differing periods of record. Second, the method probably does not account for rain-shadow and other localized meteorological effects. Third, the percentages used to compute recharge are only estimates; these values have never been systematically measured. In spite of the uncertainties, however, the estimates of potential recharge provide a basis for developing water budgets.

Estimated potential recharge from infiltration of precipitation in each of the basins of the study area are as follows (table 5):

(1) Upper Maggie Creek, about 16,000 acre-ft/yr;

(2) lower Maggie Creek, about 990 acre-ft/yr;

(3) Marys Creek, about 1,300 acre-ft/yr; and

(4) Susie Creek, about 6,400 acre-ft/yr.

The combined annual total for the three basins of the study area is about 25,000 acre- $\mathrm{ft} / \mathrm{yr}$. The basin values are nearly the same as earlier estimates (Scott and others, 1971, p. 43).

Underflow into the study area from adjacent basins is probably negligible because water levels are much lower in basins to the west, and in basins to the east, directions of ground-water flow are toward the south and east (Eakin and Lamke, 1966, pl. 1). Within the study area, ground water flows through Schroeder Mountain from the upper Maggie Creek Basin to the lower Maggie Creek Basin (fig. 22). Ground-water 
Table 5. Estimated potential ground-water recharge from precipitation in study area'

[Abbreviations: $\mathrm{ft} / \mathrm{yr}$; feet per year; acre-ft/yr, acre-feet per year; --, not applicable]

\begin{tabular}{|c|c|c|c|c|c|c|c|c|}
\hline \multirow{2}{*}{$\begin{array}{c}\text { Altitude zone } \\
\text { (feet above } \\
\text { sea level) }\end{array}$} & \multicolumn{2}{|c|}{ Precipitation } & \multicolumn{2}{|c|}{ Upper Maggie Creek } & \multicolumn{2}{|c|}{ Lower Maggle Creek } & \multicolumn{2}{|c|}{ Marys Creek } \\
\hline & $\begin{array}{c}\text { Average }^{2} \\
\text { (ft/yr) }\end{array}$ & $\begin{array}{l}\text { Percent as } \\
\text { recharge }^{3}\end{array}$ & $\begin{array}{c}\text { Area } \\
\text { (acres) }\end{array}$ & $\begin{array}{l}\text { Potentlal } \\
\text { recharge } \\
\text { (acre-ft/yr) }\end{array}$ & $\begin{array}{c}\text { Area } \\
\text { (ecres) }\end{array}$ & $\begin{array}{l}\text { Potentlal } \\
\text { recharge } \\
\text { (acre-ft/yr) }\end{array}$ & $\begin{array}{c}\text { Area } \\
\text { (acres) }\end{array}$ & $\begin{array}{c}\text { Potentlal } \\
\text { recharge } \\
\text { (acre-ft/yr) }\end{array}$ \\
\hline Above 8,000 & 1.8 & 25 & 1,100 & 500 & 0 & 0 & 0 & 0 \\
\hline $7,000-8,000$ & 1.5 & 15 & 26,100 & 5,900 & 539 & 120 & 1,120 & 250 \\
\hline $6,000-7,000$ & 1.2 & 7 & 93,600 & 7,900 & 3,720 & 310 & 8,730 & 730 \\
\hline Below $6,000^{4}$ & .9 & 2 & 97,000 & 1,700 & 31,300 & 560 & 19,800 & 360 \\
\hline Totals & -- & -- & 218,000 & 16,000 & 35,600 & 990 & 29,600 & 1,300 \\
\hline
\end{tabular}

\begin{tabular}{|c|c|c|c|c|c|c|}
\hline \multirow{2}{*}{$\begin{array}{c}\text { Altitude zone } \\
\text { (feet above } \\
\text { sea level) }\end{array}$} & \multicolumn{2}{|c|}{ Preclpltation } & \multicolumn{2}{|c|}{ Susie Creek } & \multicolumn{2}{|c|}{$\begin{array}{c}\text { Comblned three-basin } \\
\text { area }\end{array}$} \\
\hline & $\begin{array}{c}\text { Average } 1 \\
\text { (ft/yr) }\end{array}$ & $\begin{array}{l}\text { Percent as } \\
\text { recharge } 1\end{array}$ & $\begin{array}{c}\text { Area } \\
\text { (acres) }\end{array}$ & $\begin{array}{l}\text { Potentlal } \\
\text { recharge } \\
\text { (acre-ft/yr) }\end{array}$ & $\begin{array}{c}\text { Area } \\
\text { (ecres) }\end{array}$ & $\begin{array}{c}\text { Potential } \\
\text { recharge } \\
\text { (acre-ft/yr) }\end{array}$ \\
\hline Above 8,000 & 1.8 & 25 & 54 & 24 & 1,160 & 520 \\
\hline $7,000-8,000$ & 1.5 & 15 & 3,060 & 690 & 30,800 & 6,900 \\
\hline $6,000-7,000$ & 1.2 & 7 & 55,200 & 4,600 & 161,000 & 14,000 \\
\hline Below $6,000^{1}$ & .9 & 2 & 59,100 & 1,100 & 207,000 & 3,700 \\
\hline Totals & -- & -- & 117,000 & 6,400 & 400,000 & 25,000 \\
\hline
\end{tabular}

\footnotetext{
${ }^{1}$ Areas rounded to three significant figures; recharge estimates rounded to two significant figures.

${ }^{1}$ Computed from precipitation-altitude relation developed as part of study.

${ }^{1}$ For altitude zones above 6,000 feet, percent of precipitation as recharge taken from Eakin (1961, p. 20); for zone below 6,000 feet, percent from Stone (1992, p. 4-5).

${ }^{1}$ Lowest part of this zone is along Humboldt River flood plain at altitude of about 4,900 feet.
}

flow lines indicate that the recharge area for this underflow is at the south end of the Tuscarora Mountains (fig. 22) where estimated potential recharge is probably no more than a few hundred acre-feet per year. Large quantities of ground water probably do not move through the mountain. Total underflow through Schroeder Mountain to the lower Maggie Creek Basin probably does not exceed 1,000 acre-ft/yr.

Infiltration of streamflow is a source of recharge to the aquifer in the lower Maggie Creek Basin. In a previous section of this report, "Surface Water," the capacity of the lower Maggie Creek channel to transmit water to underlying aquifers was estimated to be 10-20 $\mathrm{ft}^{3} / \mathrm{s}$. If the lower value is used as a conservative estimate, recharge from Maggie Creek to the lower basin is an estimated 7,000 acre-ft/yr.

Ground water also flows between lower Maggie Creek Basin and lower parts of the Marys Creek Basin through volcanic rocks and adjacent basin-fill deposits.
Ground-water flow lines (fig. 22) indicate that much of this underflow discharges at Carlin spring. The total flow of the spring, including the municipal diversion, is an estimated 3,000 acre-ft/yr $\left(4 \mathrm{ft}^{3} / \mathrm{s}\right)$. Total underflow between the two basins probably exceeds 3,000 acre$\mathrm{ft} / \mathrm{yr}$ because all of the underflow does not necessarily discharge at Carlin spring. Some also discharges directly into the Humboldt River channel.

\section{Discharge}

Ground-water discharge is the result of four processes in the study area:

(1) Evapotranspiration from phreatophytes and bare soil,

(2) underflow between basins,

(3) ground-water discharge to stream channels, and

(4) pumping for mining and agriculture (see next section). 
Evapotranspiration is a process that consumes soil moisture and ground water throughout the study area. It also is the process that controls the percentage of annual precipitation that becomes ground-water recharge.

Evapotranspiration of ground water is limited to areas where water levels are sufficiently shallow that ground water is used by phreatophytes. Phreatophytes are defined as plants that obtain their water directly from the water table (Robinson, 1958, p. 10). The most common phreatophytes in the study area are big sage (Artemisia tridentata), rabbitbrush (Chrysothamnus sp.), greasewood (Sarcobatus vermiculatus), willow (Salix), small areas of saltgrass (Distichlis stricta), and various grasses in meadows (Harrington, 1954). These plants, especially the shrubs, occupy low-lying areas, generally along stream flood plains where water levels are no deeper than 40-60 ft below land surface (fig. 23).

Differing rates of ground-water usage have been defined for phreatophytes in the Great Basin. In early studies, the rates were empirically determined. In water-budget studies for Pine and Huntington Valleys south and southeast of the present study area, rates of ground-water use by evapotranspiration were estimated to be $0.1-0.5 \mathrm{ft} / \mathrm{yr}$ for greasewood, rabbitbrush, saltgrass, and willow where depths to water range from a few feet to $20 \mathrm{ft}$ below land surface. Rates of $0.75-1.25 \mathrm{ft} / \mathrm{yr}$ were used where water is near land surface in meadows and pastures (Eakin, 1961, p. 22, and Rush and Everett, 1966, p. 22).

Micrometeorological methods for quantifying the components of the energy budget near the ground surface have been applied to determine evapotranspiration rates at several sites in central and northern Nevada in the summers of 1991 and 1992 (M.J. Johnson, U.S. Geological Survey, written commun., 1993). Three of the sites are in the upper Maggie Creek Basin (fig. 23).

Evapotranspiration rates were measured from July 24 to August 7, 1991, at site 1 (fig. 23), where phreatophytes consist of rabbitbrush and grass. Rates were measured from June 20 to July 7, 1992, at site 2, where phreatophytes also consist of rabbitbrush and grass, and at site 3, where phreatophytes consist of meadow grass. Average daily evapotranspiration rates measured at the three sites were $0.0046 \mathrm{ft} / \mathrm{d}$ at site 1 , $0.0059 \mathrm{ft} / \mathrm{d}$ at site 2, and $0.0089 \mathrm{ft} / \mathrm{d}$ at site 3 (M.J. Johnson, written commun., 1993). The evapotranspiration rate at site 3 was higher than at the other two sites because the plant density in areas of meadow grass is greater than in areas of rabbitbrush and grass. In addi- tion, water levels were at or near land surface in areas of meadow grass, but ranged from about $10 \mathrm{ft}$ to more than $30 \mathrm{ft}$ below land surface in areas of rabbitbrush.

Nichols (1993, p. 2775) concluded that the annual growing season for greasewood in central and northern Nevada ranges from 140 to 165 days. During the first 40-65 days of the season, soil moisture derived from winter precipitation sustains the plants, and for the remaining 100 days the plants use ground water (Nichols, 1993, p. 2775). If this conclusion is applied to the rates measured at the sites in the upper Maggie Creek Basin, annual rates of ground-water evapotranspiration are an estimated $0.5 \mathrm{ft} / \mathrm{yr}$ in areas of rabbitbrush and grass and $0.9 \mathrm{ft} / \mathrm{yr}$ in areas of meadow grass. The rate for rabbitbrush and grass also was used for areas of greasewood.

In upper Maggie Creek Basin, phreatophytes cover an estimated 12,700 acres (table 6). Phreatophytes consist mostly of meadow grass and willow in lowlands along Maggie Creek and its principal tributaries, whereas big sage and rabbitbrush occupy much larger areas beyond the meadows. The two phreatophyte types are not distinguished in figure 23 . On the basis of field mapping, the estimated area of each type is 1,800 acres of meadow grass and willow (rate of $0.9 \mathrm{ft} / \mathrm{yr}$ ) and 10,900 acres of big sage and rabbitbrush $(0.5 \mathrm{ft} / \mathrm{yr})$. Using these areas and rates, evapotranspiration in the upper Maggie Creek Basin is an estimated 7,100 acre-ft/yr.

Phreatophytes in lower Maggie Creek Basin cover an estimated 3,380 acres (table 6). Big sage, rabbitbrush, and meadow grass are the principal phreatophytes in the basin, although greasewood is common near the Humboldt River. The total area also includes about 400 acres of irrigated agriculture, where annual evapotranspiration rates are an estimated $1 \mathrm{ft} / \mathrm{yr}$. If annual rates of $0.5 \mathrm{ft} / \mathrm{yr}$ are applied to areas of big sage, rabbitbrush, greasewood, and meadow grass and $1 \mathrm{ft} / \mathrm{yr}$ is applied to irrigated areas, then total groundwater discharge by evapotranspiration is an estimated $1,900 \mathrm{acre}-\mathrm{ft} / \mathrm{yr}$.

The principal phreatophytes in the Susie Creek Basin are greasewood near the Humboldt River and big sage and rabbitbrush in other parts of the basin. The total area of phreatophytes is about 3,480 acres (table 6 ). The estimated annual evapotranspiration rate from ground water is $0.5 \mathrm{ft} / \mathrm{yr}$, and total ground-water discharge is about 1,700 acre- $\mathrm{ft} / \mathrm{yr}$. 


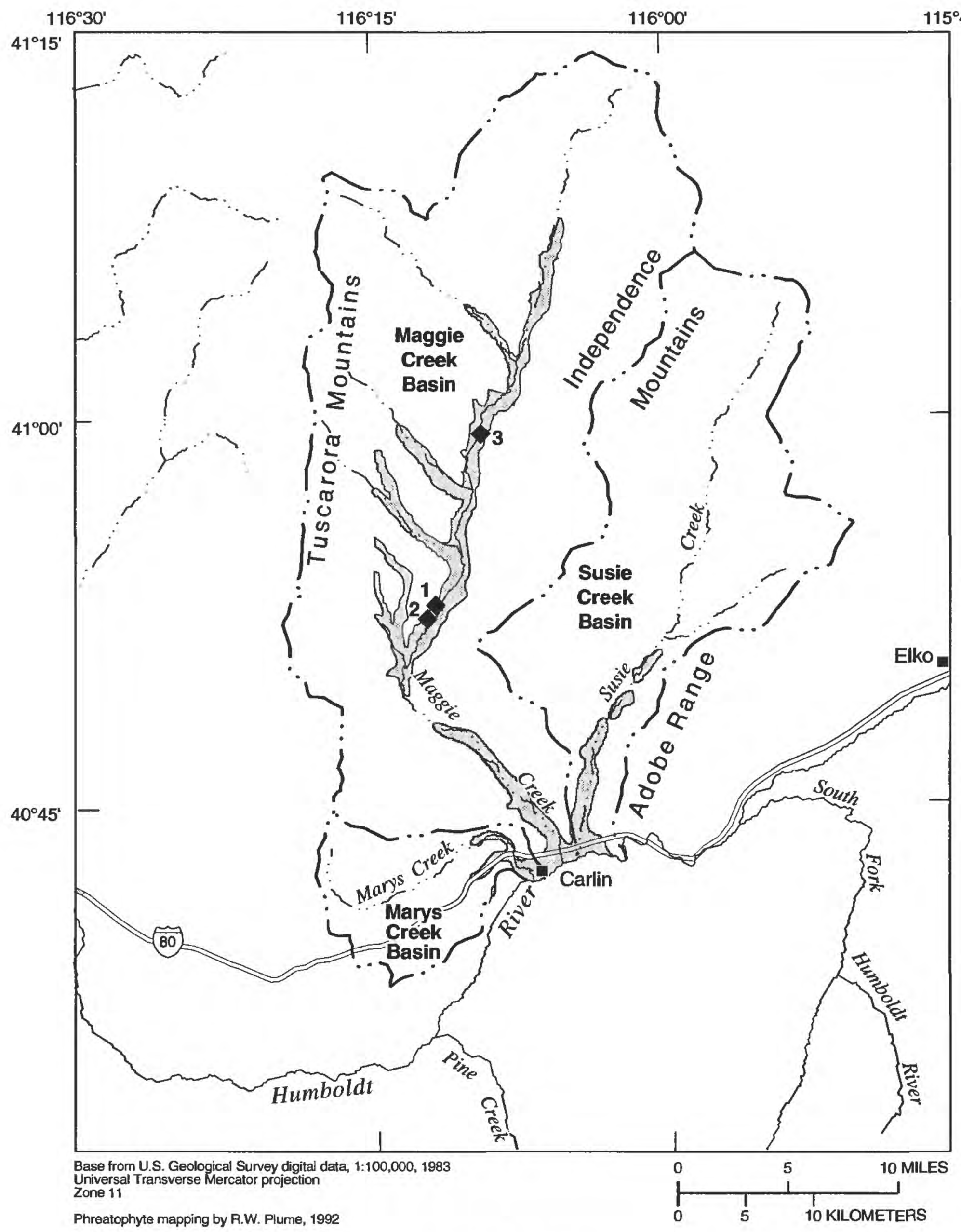

EXPLANATION

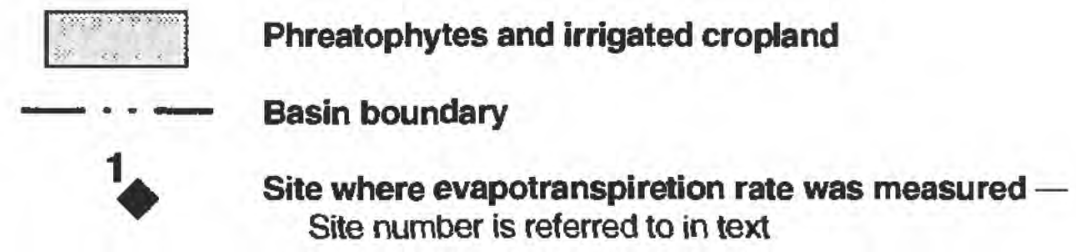

Figure 23. Distribution of phreatophytes and irrigated cropland in study area, northeastern Nevada. 
Table 6. Estimated long-term ground-water discharge in study area, northeastern Nevada

[Totals rounded to nearest 1,000. Abbreviations: acre-ft/yr, acre-feet per year; $\mathrm{ft}^{3} / \mathrm{s}$, cubic feet per second; ft/yr, feet per year]

\begin{tabular}{|c|c|c|c|c|c|}
\hline \multirow[b]{2}{*}{ Item } & \multicolumn{2}{|c|}{ Maggle Creek } & \multirow[b]{2}{*}{$\begin{array}{l}\text { Marys } \\
\text { Creek }\end{array}$} & \multirow[b]{2}{*}{$\begin{array}{l}\text { Susie } \\
\text { Creek }\end{array}$} & \multirow[b]{2}{*}{$\begin{array}{l}\text { Total for } \\
\text { three-basin } \\
\text { study area }\end{array}$} \\
\hline & Upper & Lower & & & \\
\hline \multicolumn{6}{|c|}{ Evapotranspiration } \\
\hline Rate (ft/yr) & (1) & (2) & (3) & ${ }^{4} 0.5$ & $(5)$ \\
\hline $\begin{array}{l}\text { Area of phreatophytes } \\
\text { (acres) }\end{array}$ & 12,700 & 3,380 & 970 & 3,480 & 20,000 \\
\hline $\begin{array}{l}\text { Annual volume } \\
\text { (acre-ft/yr) }\end{array}$ & 7,100 & 1,900 & 700 & 1,700 & 11,000 \\
\hline \multicolumn{6}{|c|}{ Springflow and discharge to stream channeis } \\
\hline $\begin{array}{l}\text { Annual volume } \\
\text { (acre-ft/yr) }\end{array}$ & ${ }^{7} 4,000$ & (8) & ${ }^{9} 3,000$ & (8) & ${ }^{10} 7,000$ \\
\hline \multicolumn{6}{|c|}{ Underflow } \\
\hline $\begin{array}{l}\text { Annual volume } \\
\text { (acre-ft/yr) }\end{array}$ & ${ }^{11} 1,000$ & 123,000 & 0 & 0 & 0 \\
\hline \multicolumn{6}{|c|}{ Basin totals 13} \\
\hline & 12,000 & ${ }^{8} 5,000$ & ${ }^{8} 4,000$ & ${ }^{8} 2,000$ & 18,000 \\
\hline
\end{tabular}

\footnotetext{
${ }^{1}$ Rates used were $0.5 \mathrm{ft} / \mathrm{yr}$ for 10,900 acres of big sage and rabbitbrush and $0.9 \mathrm{ft} / \mathrm{yr}$ for 1,800 acres of meadow grass and willow.

${ }^{2}$ Rates used were $0.5 \mathrm{ft} / \mathrm{yr}$ for 2,980 acres of big sage and rabbitbrush and $1 \mathrm{ft} / \mathrm{yr}$ for 400 acres of irrigated agriculture.

${ }^{3}$ Rates used were $0.5 \mathrm{ft} / \mathrm{yr}$ for 520 acres of big sage and rabbitbrush and $0.9 \mathrm{ft} / \mathrm{yr}$ for 450 acres of willow and meadow grass.

${ }^{4}$ Rate used was $0.5 \mathrm{ft} / \mathrm{yr}$ for greasewood near the Humboldt River and for big sage and rabbitbrush in other parts of the basin.

${ }^{5}$ Average rate for three-basin area not computed.

${ }^{6}$ Computed as product of area of phreatophytes and rate (rounded to nearest 100 ).

${ }^{7}$ Value based on minimum baseflow of Maggie Creek of $5 \mathrm{ft}^{3} / \mathrm{s}$.

${ }^{8}$ Discharge to Humboldt River channel could not be reliably measured.

${ }^{9}$ Value is based on estimated average discharge of Carlin spring $\left(4 \mathrm{ft}^{3} / \mathrm{s}\right)$. Value does not include additional discharge to Humboldt River channel.

${ }^{10}$ Estimated total study-area discharge to Humboldt River channel based on minimum October baseflow $\left(10 \mathrm{ft}^{3} / \mathrm{s}\right)$ for Humboldt River.

${ }^{11}$ Estimated underflow to lower Maggie Creek Basin.

${ }^{12}$ Underflow from lower Maggie Creek Basin to Marys Creek Basin, estimated as flow of Carlin spring.

${ }^{13}$ Values are column totals of evapotranspiration, springflow and discharge to stream channels, and underflow. Totals for individual basins are believed to be low because discharge to the reach of the Humboldt River channel adjacent to each basin could not be quantified.
} 
Phreatophytes cover an estimated 970 acres in the Marys Creek Basin (table 6). They consist of about 520 acres of big sage and rabbitbrush $(0.5 \mathrm{ft} / \mathrm{yr})$ to the north and west and about 450 acres of willows and meadow grass $(0.9 \mathrm{ft} / \mathrm{yr})$ from Carlin spring to the Humboldt River. Using these areas and rates, the estimated annual ground-water discharge by way of evapotranspiration is 700 acre- $\mathrm{ft} / \mathrm{yr}$.

Ground-water underflow between basins of the study area was discussed as a recharge source in the previous section of this report. Underflow from the upper Maggie Creek Basin through Schroeder Mountain to the lower basin is estimated to be 1,000 acre$\mathrm{ft} / \mathrm{yr}$ or less (table 6). Underflow from lower Maggie Creek Basin to Carlin spring in Marys Creek Basin is estimated to be at least 3,000 acre-ft/yr (table 6).

Ground-water discharge that sustains the baseflow of a stream is listed in table 6 as the total of spring-flow near the stream and inflow directly into the channel because the two cannot always be distinguished. In the upper Maggie Creek basin, total ground-water discharge to the Maggie Creek channel is estimated to be 4,000 acre-ft/yr based on the estimated minimum baseflow of the stream $\left(5 \mathrm{ft}^{3} / \mathrm{s}\right)$ adjacent to the unnamed hills.

The individual contribution of ground-water discharge from each basin of the study area to the Humboldt River could not be quantified because streamflow gains or losses were difficult to measure over the short reach of the river adjacent to each basin. However, combined discharge to the longer reach of river channel adjacent to the three basins of the study area was measured and is an estimated 7,000 acre-ft/yr. This includes inflow directly to the river channel and the discharge of Carlin spring and two other unnamed springs nearby (sites 103, 106, and 107; table 12). The orifice for one of the springs (site 103) is at the base of bluffs north of the Humboldt River about 3 mi southwest of Carlin. The spring is not in Marys Creek Basin, but all of its discharge originates in the basin.

\section{Use}

The principal uses of ground water in the study area are agriculture, mining, and municipal (table 4). Agricultural uses are subdivided into irrigation of crops and watering stock. Only two irrigation wells are in use in the study area. Total annual pumpage permitted at the two wells is 1,782 acre-ft/yr; however, that pumpage depends in part on the amount of surface water diverted from Maggie Creek. Each of the wells produces $1,800-2,000 \mathrm{gal} / \mathrm{min}$ and neither is operated for more than 90 days each year (Wayne Fahsholtz, Maggie Creek Ranch, oral commun., 1992). A rate of $2,100 \mathrm{gal} / \mathrm{min}$ was measured at well 25 (table 13) in June 1990 using the trajectory method for estimating discharge from a horizontal pipe (Howe, 1950, p. 226). Pumping at this rate for 90 days at both wells would constitute an annual rate of about 1,700 acre-ft/yr.

Livestock use of ground water is small compared with other uses in the study area. The Nevada Division of Water Resources permits pumpage of $20 \mathrm{gal} / \mathrm{d}$ for large animals such as horses and cows. The study area supports about 4,000 head of cattle year round. At a daily rate of 20 gallons per animal, pumpage of ground water for livestock is an estimated 90 acre-ft/yr. The actual value may be somewhat less because streamflow, where available, also is used to supply livestock needs.

Pumpage for industrial use of ground water in the study area is dominated by the mining industry. In 1985, about 790 acre-ft of ground water was pumped for mining use; by 1989-90, pumpage had increased to 6,000-7,000 acre-ft/yr (table 4). This ground water was consumptively used for processing ore, dust control, and other aspects of mining. Beginning in 1993, the pumping rate increased when dewatering of Gold Quarry mine began. The annual rate may reach 70,000 acre- $\mathrm{ft} / \mathrm{yr}$ in the later stages of dewatering, in about the year 2000 (C.J. Zimmerman, written commun., 1992). To the extent possible, this water will be used for mining and milling and for irrigating cropland; however, as much as 50,000-60,000 acre-ft/yr will leave the area by way of Maggie Creek and the Humboldt River.

Municipal use of well water in the study area began in 1989, when a well was drilled near Carlin to supplement diversions from Carlin spring. Pumpage from this well was 0.2 acre-ft in 1989 and 3 acre-ft in 1990 (table 4). 


\section{Chemical and Isotopic Composition of the Water}

\section{Chemical Composition of Ground Water}

As a part of the study, water samples were collected at 14 wells and 7 springs (fig. 24). Samples from 13 of the wells and 4 of the springs were analyzed for overall chemical composition, which is summarized in the diagram in figure 25 . The diagram consists of five fields - two triangular and three rectangular. Each chemical analysis is plotted as five points in the diagram. In combination, the five points plotted for each sample provide a general idea of the overall chemical character of the water. The relative proportions, in percent of total milliequivalents, of major cations (calcium, magnesium, sodium, and potassium) and major anions (sulfate, chloride, and bicarbonate) are shown on the left and upper triangles, respectively. The $\mathrm{pH}$ and dissolved-solids concentration for each sample are shown on the bottom and right rectangles, respectively. The arrows in figure 25 show how values for the analysis of a sample for site 36 are plotted in the triangular fields and are projected, by way of the central rectangle, to the fields for $\mathrm{pH}$ and dissolved solids.

The general chemical character of ground water in the Maggie Creek study area does not differ much from sample sites near recharge areas to sites near discharge areas. With two exceptions, the ground water is a calcium to sodium bicarbonate type (fig. 25). The water is near neutral: $\mathrm{pH}$ ranges from 6.6 to 7.9. Dissolved-solids concentrations range from less than 100 to $345 \mathrm{mg} / \mathrm{L}$.

The two sites with ground water that differs chemically from the other sampled ground water are a spring near a mineralized area and mine dumps in the Tuscarora Mountains and a well finished in basin-fill deposits along the edge of the Humboldt River flood plain (sites 101 and 36; tables 12 and 13 and fig. 24). Water from the spring is a calcium sulfate type. The dissolved-solids content is $1,240 \mathrm{mg} / \mathrm{L}$. The $\mathrm{pH}$ of 6.6 at this spring was one of the two lowest values measured in the study area. The slightly acidic $\mathrm{pH}$ in this water suggests that it has been in contact with sulfide minerals in mineralized zones or in mine dumps.

Ground water from site 36, the well along the edge of the Humboldt River flood plain, is a sodium sulfate type. The dissolved-solids content of 1,550 $\mathrm{mg} / \mathrm{L}$ was the highest value measured in the study area. Possible reasons for the different chemical quality of the water are evaporite beds in the basin-fill deposits penetrated by the well or contamination from an unidentified source.

\section{Isotopic Composition of Ground Water and Surface Water}

Many chemical elements have more than one isotope. All isotopes of an element have the same number of protons in the atomic nucleus but have differing numbers of neutrons. Thus, the isotopes of an element all have the same atomic number but have different atomic weights. Two types of isotopes-radioactive and stable-were used herein to estimate ages of ground water and to evaluate conclusions made earlier regarding sources of recharge and possible mixing of water from different sources.

Radioactive isotopes undergo radioactive decay. This means that the isotope eventually decays into a lighter element and, in the process, emits atomic particles. Analyses of radioactive isotopes are useful for estimating the length of time since recharge of the water, or age. Concentrations of radioactive isotopes are expressed in picocuries per liter ( $\mathrm{pCi} / \mathrm{L})$.

Concentrations of the radioactive isotope, tritium, in ground water from 10 wells and 5 springs in the lower Maggie Creek area are shown in figure 26. Eleven of the sites were sampled as a part of the study. Tritium values for water at the other four sites were provided by Newmont Gold Co. (C.J. Zimmerman, written commun., 1991). Water samples from six of the sites had values less than the analytical detection limit of $0.3 \mathrm{pCi} / \mathrm{L}$. Two samples had a value of $6 \mathrm{pCi} / \mathrm{L}$, and seven had values that ranged from 12 to $60 \mathrm{pCi} / \mathrm{L}$. Values less than $0.3 \mathrm{pCi} / \mathrm{L}$ indicate ground water older than about 60 years, whereas values of $6 \mathrm{pCi} / \mathrm{L}$ indicate that the sampled ground water is about $40-60$ years old (Robertson and Cherry, 1989, p. 1108). Ground water with values of $6 \mathrm{pCi} / \mathrm{L}$ or less came from relatively deep wells finished in basin-fill deposits and carbonate rocks at Schroeder Mountain, and from two unnamed springs southwest of Carlin (sites 103 and 107; table 12 and fig. 26).

Tritium values of $12-60 \mathrm{pCi} / \mathrm{L}$ indicate that the ground water was recharged in the last 40 years. Four of these sites are two springs near recharge areas in the southern Tuscarora Mountains and Marys Mountain, a well along a tributary of upper Maggie Creek, and a well near the Humboldt River flood plain (sites 102, 105,67 , and 36; tables 12 and 13 and figs. 24 and 26). 


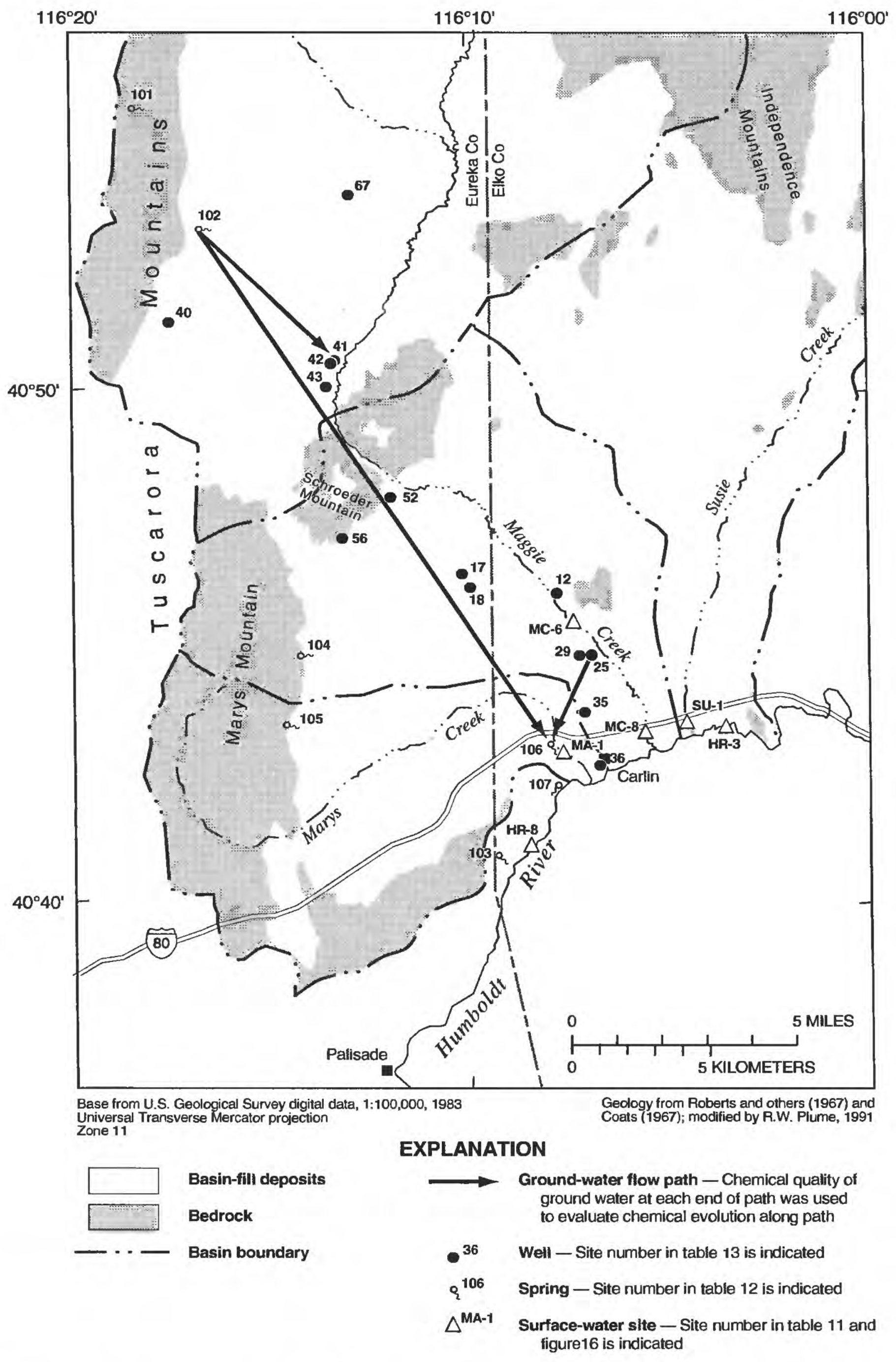

Figure 24. Locations of wells, springs, and surface-water sites sampled for water quality in lower Maggie Creek area, northeastern Nevada 
NOTE: TRILINEAR PLOTS INDICATE PERCENTAGES, ON BASIS OF MILLIEQUIVALENTS PER LITER
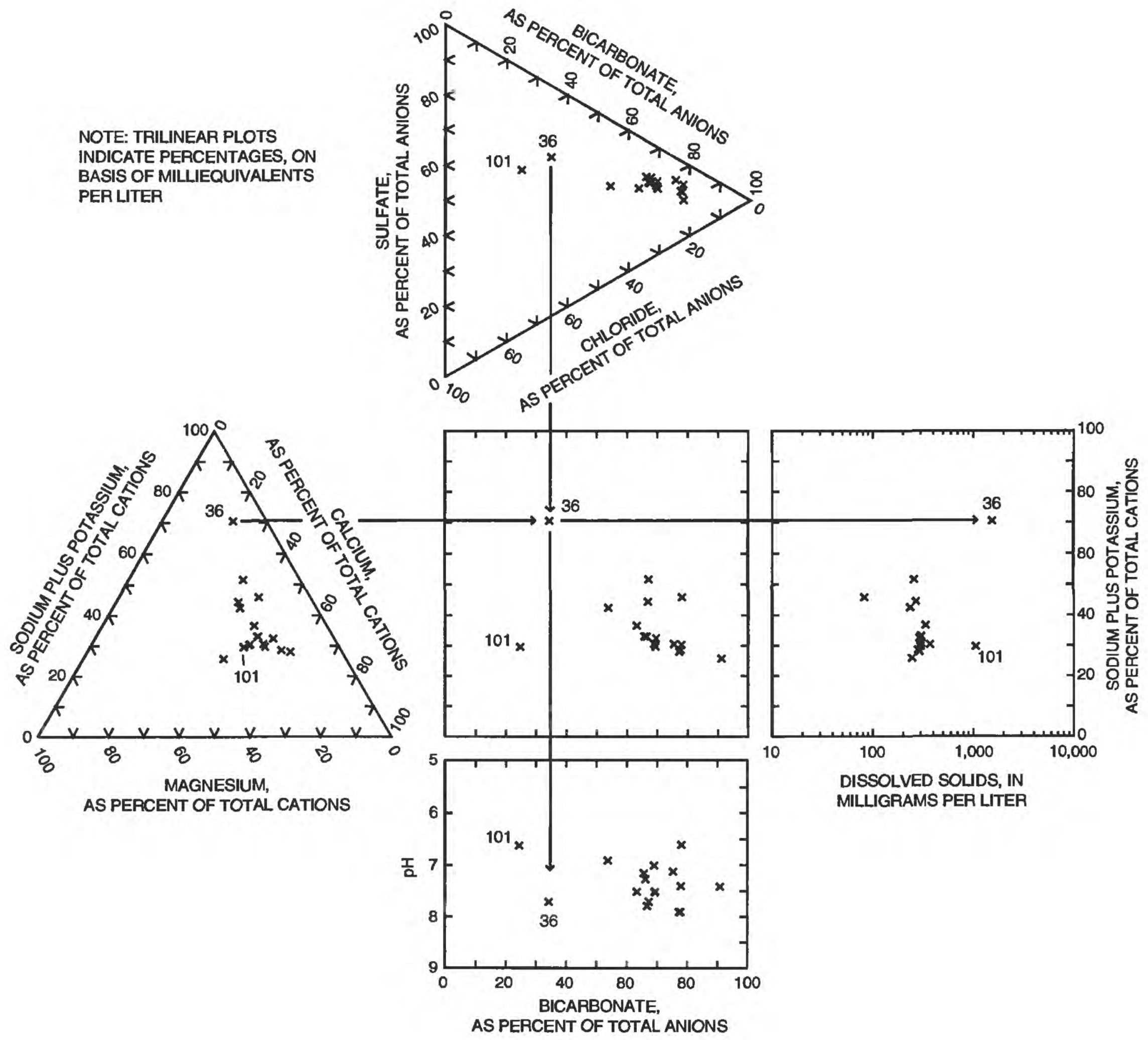

Figure 25. General chemical character of sampled ground water in lower Maggie Creek area, northeastern Nevada. Arrows show projection of values for a single sample (from site 36) from triangles to rectangles, indicating water type, $\mathrm{pH}$, and dissolved-solids concentration of sample. 


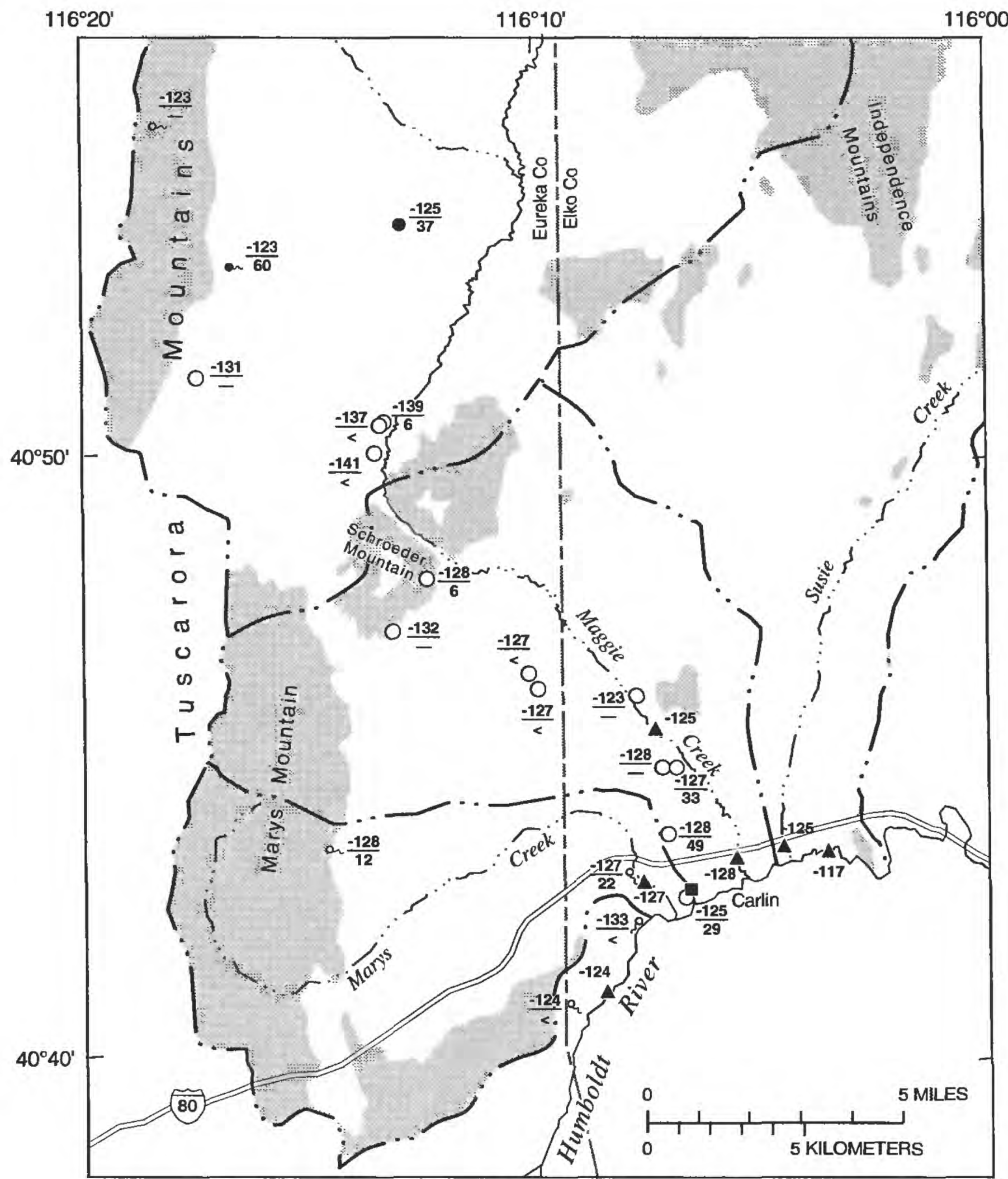

Base from U.S. Geological Survey digital data. 1:100,000, 1983 Universal Transverse Mercator projection

O $\frac{-128}{49}$ Well - Sampled by U.S. Geological Survey (USGS) for deuterium; selected sites also sampled for tritium. Top number is deuterium value, in permil. Bottom number or symbol indicates as follows: number is tritium value, in picocuries per liter $(\mathrm{pCi} / \mathrm{L})$; <, tritium value Jess than analytical reporting limit of $0.3 \mathrm{pCi} / \mathrm{L} ;-$, no tritium analysis available

$\frac{-125}{37}$ Well - Sampled by USGS for deuterium and by Newmont Gold Co. for tritium. Top number is deuterium value, in permil. Bottom number is tritium value, in $\mathrm{pCi} / \mathrm{L}$

an $\frac{-128}{12}$ Spring - Sampled by USGS for deuterium; selected sites also sampled for tritium. Top number is deuterium value, in permil. Bottom number or symbol indicates as follows: number is tritium value, in $\mathrm{pCi} / \mathrm{L} ;<$, tritium value less than analytical reporting limit of $0.3 \mathrm{pCi} / \mathrm{L} ;-$, no tritium analysis available

a $\frac{-123}{60}$ Spring - Sampled by USGS for deuterium and by Newmont Gold Co. for tritium. Top number is deuterium value, in permil. Bottom number or symbol indicates as follows: number is tritium value, in $\mathrm{pCi} / \mathrm{L} ;<$, tritium value less than analytical reporting limit of $0.3 \mathrm{pCi} / \mathrm{L}$

$A^{-124}$ Surface-water site - Number is deuterium value, in permil

Figure 26. Areal distribution of tritium and deuterium for ground water and surface water in lower Maggie Creek area, northeastem Nevada. 
Tritium values for these sites were $60,12,37$, and 29 $\mathrm{pCi} / \mathrm{L}$, respectively. The source of water from the two springs most likely is high-altitude recharge from nearby mountains. The source of water from the two wells is probably leakage of streamflow, because both wells are shallow and near the stream.

Three other ground-water sites having high tritium values are an irrigation well along Maggie Creek, a municipal well between Maggie Creek and Carlin spring, and Carlin spring (sites 25, 35, and 106; tables 12 and 13 and figs. 24 and 26). Both wells are finished partly in volcanic rocks. Tritium values were $33 \mathrm{pCi} / \mathrm{L}$ at the irrigation well, $49 \mathrm{pCi} / \mathrm{L}$ at the municipal well, and $22 \mathrm{pCi} / \mathrm{L}$ at the spring. The values suggest that streamflow from Maggie Creek enters the volcanic rocks along the stream channel, moves rapidly southward through the rocks, and discharges at the spring. Residence times of the water in the volcanic rocks cannot be computed accurately because the tritium content of streamflow when it became ground-water recharge is not known. However, the small change in tritium values between the irrigation well and Carlin spring indicate short residence times for the water, possibly less than 20-30 years.

Stable isotopes do not undergo radioactive decay. Their concentrations are indirectly determined as a proportion that is the ratio of the concentration of the isotope of interest to the most abundant isotope of the same element. Isotopic values are expressed as the difference between the measured ratio and the ratio of an accepted standard. For example, the stable isotope oxygen-18 $\left({ }^{18} \mathrm{O}\right)$ has two more neutrons in its atomic nucleus than the more abundant form, oxygen-16 $\left({ }^{16} \mathrm{O}\right)$. The proportion of ${ }^{18} \mathrm{O}$ in a water sample is expressed as the amount, in permil, by which the ratio ${ }^{18} \mathrm{O} /{ }^{16} \mathrm{O}$ differs from the accepted standard. This deviation of ${ }^{18} \mathrm{O} /{ }^{16} \mathrm{O}$ from the standard is termed delta oxygen-18 and is expressed as $\delta^{18} \mathrm{O}$.

Stable isotopes, especially the lighter ones, are useful in hydrologic studies because their proportions change as a result of geochemical, biological, and physical processes. The difference resulting from these processes is called isotopic fractionation. During evaporation, for example, $\delta^{18} \mathrm{O}$ increases because ${ }^{16} \mathrm{O}$ is lighter and leaves the water at a greater rate than the heavier ${ }^{18} \mathrm{O}$. As a result, the remaining water becomes enriched in ${ }^{18} \mathrm{O}$ compared with ${ }^{16} \mathrm{O}$ during evaporation. The water, after evaporation, is said to be isotopically heavier compared to the original water. The terms isotopically heavier and isotopically lighter are relative and are used for comparing the composition of water samples.

Figure 27 shows the relation of $\delta^{18} \mathrm{O}$ to $\delta \mathrm{D}$ (delta deuterium) in ground and surface water in the lower Maggie Creek area. Deuterium is a stable isotope of hydrogen. The data on this graph represent ground water from wells and springs and surface water, sampled during baseflow conditions, from Maggie, Marys, and Susie Creeks and the Humboldt River (see fig. 24 for sample locations). The isotopically lightest ground water sampled in the lower Maggie Creek area came from three flowing wells (sites 41,42 , and 43 ; figs. 24 , 26 , and 27). These wells penetrate relatively deep parts of the basin-fill aquifer in the upper Maggie Creek Basin along the west side of the Schroeder Mountain uplift. This ground water probably originated as highaltitude recharge in the Tuscarora and Independence Mountains in the northern part of the upper Maggie Creek Basin.

Isotopically light ground water similar to that at the three flowing wells was not found in the lower Maggie Creek Basin. In this part of the study area, ground water from wells is isotopically heavier (figs. 26 and 27), which suggests that most highaltitude recharge from northern parts of the Tuscarora and Independence Mountains is discharged in the upper Maggie Creek Basin. The data support the conclusion made in a previous section that ground-water underflow between the basins of upper and lower Maggie Creek is minimal. Ground water that discharges into the channel of upper Maggie Creek may be isotopically light when it enters the stream channel. However, the water is isotopically heavier because of evaporation by the time it is available as a source of recharge in the lower Maggie Creek Basin (fig. 27).

Ground water that is isotopically heavier than water from the three flowing wells came from relatively shallow wells and springs in the southern part of the upper Maggie Creek Basin, lower Maggie Creek Basin, and the Marys Creek Basin (fig. 26). Recharge areas for ground water from these wells and springs are at altitudes $1,000-2,000 \mathrm{ft}$ lower and $10-30 \mathrm{mi}$ south of recharge areas in northern parts of the Tuscarora and Independence Mountains. The variability in composition of the isotopically heavier ground water is probably due mostly to seasonal and topographic effects. The values suggest that part of the ground-water recharge to the lower Maggie Creek area comes from nearby mountain ranges. Comparison of values for 


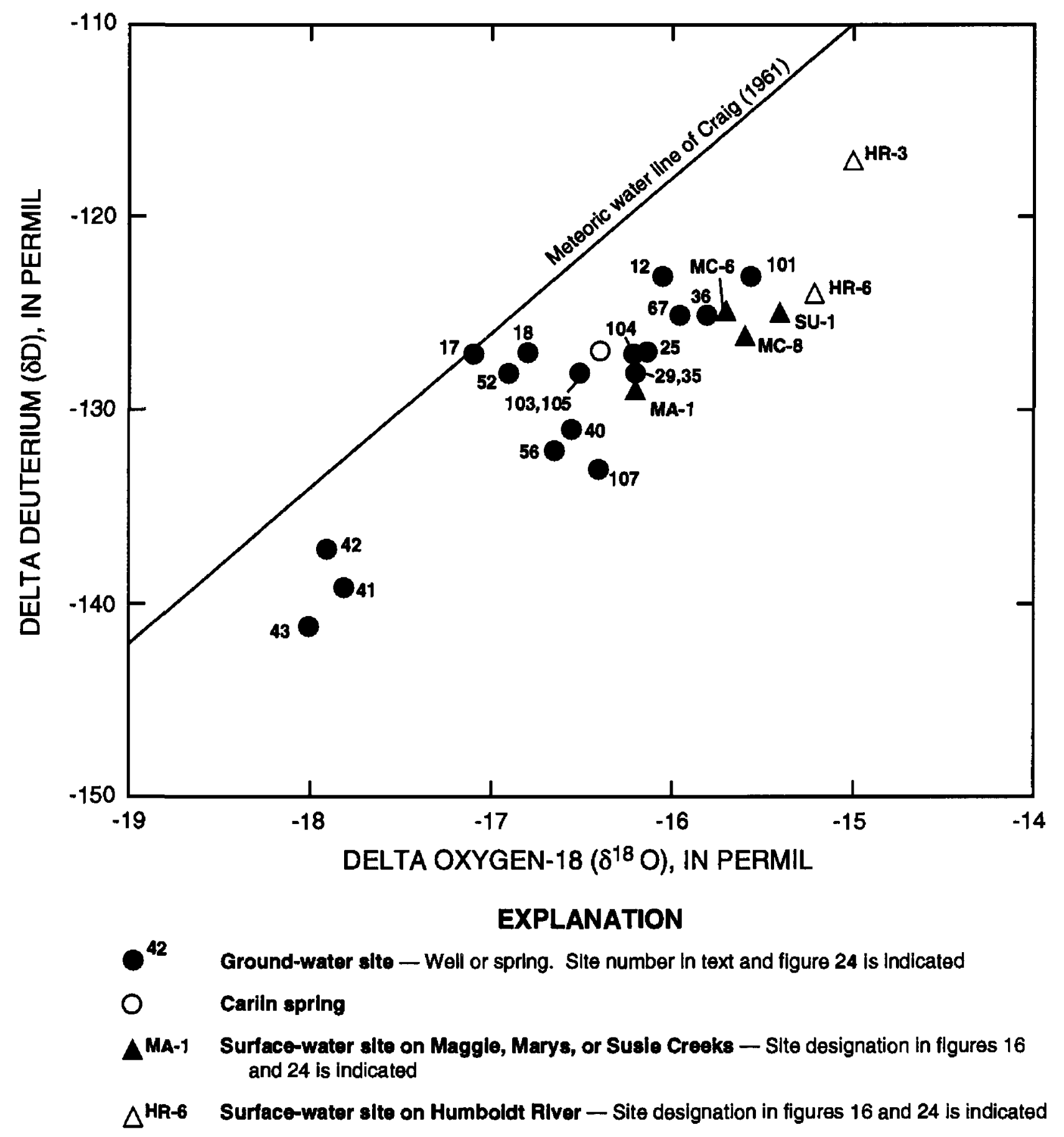

Figure 27. Relation between deuterium and oxygen-18 for ground-water and surfacewater samples in lower Maggie Creek area, northeastern Nevada. Equation for meteoric water line $\delta \mathrm{D}=8\left(\delta^{18} \mathrm{O}\right)+10$ (Craig, 1961).

ground water with values for water from Maggie and Susie Creeks also suggests that infiltration of streamflow is a source of recharge (fig. 27).

Comparison of the isotopic composition of water from the Humboldt River above and below Carlin with the composition of water at Carlin spring (sites HR-3, HR-8, and 106, respectively; fig. 24) supports a conclusion made earlier that ground water discharges into the river. Deuterium values of water in the Humboldt River on November 16, 1989, were -117 and -124 permil above and below Carlin, respectively (fig. 27). Three days earlier, the flow of the river at the two sites was about $44 \mathrm{ft}^{3} / \mathrm{s}$ above Carlin and about $54 \mathrm{ft}^{3} / \mathrm{s}$ below Carlin (table 11), indicating a gain of $10 \mathrm{ft}^{3} / \mathrm{s}$. Using the deuterium values and measured flows of the river, a mass-balance calculation can be used to com- pute an estimated gain in flow due to ground water entering the river. The equation

$$
\left(Q_{a} C_{a}\right)+\left(Q_{g} C_{g}\right)=\left(Q_{b} C_{b}\right)
$$

can be used to compute the estimated flow increase assuming that the deuterium composition at Carlin spring ( -127 permil) is representative of ground water entering the river. In the equation, $Q$ is flow, in cubic feet per second, $C$ is deuterium composition, in permil, and the subscripts indicate water from the river $(a)$ above and $(b)$ below Carlin and $(g)$ ground-water discharge. Substitutions of values for flow and deuterium composition of the river above and below Carlin and for the deuterium composition of water at Carlin spring yield a value for $Q_{g}$ of $12 \mathrm{ft}^{3} / \mathrm{s}$. This value is close to the gain of $10 \mathrm{ft}^{3} / \mathrm{s}$ measured 3 days earlier. 
Geochemical interpretation of Hypothetical Flow Paths

Geochemical mass-transfer models were used to evaluate the chemical character of ground water along four flow paths identified on the basis of geologic, hydrologic, and isotopic evidence. The models were developed using the computer program NETPATH (Plummer and others, 1991).

The program results consist of sets of reactions, each a separate hypothesized model, which attempt to account for the chemical evolution of water from an initial (recharge area) to final (discharge area) composition. Each model is constrained (1) by the chemical composition of water at a well or spring at the beginning and end of the flow path (table 14), and (2) by mineral and gas phases identified or presumed to be present and reacting with ground water along the flow path (tables 7 and 8). On the basis of these constraints, the program determines all possible reactions that could account for the chemical composition of ground water at the end of the path being evaluated. These reactions include exchange of calcium and magnesium in the water with sodium on clay minerals (cation exchange), precipitation and formation or dissolution of mineral phases, and exsolution or dissolution of carbon dioxide gas.

Each set of reactions must be evaluated to reject unreasonable models and to identify one or more reasonable ones. Models generally are rejected for either of two reasons. First, one or more reactions may indicate processes that would not be expected (precipitation of the minerals andesine or biotite, for instance). Second, the mass transfer of each phase for a particular model (table 7) should be consistent with the saturation index for the phase at the end of the flow path (table 8). For example, a model indicating dissolution of calcite along a flow path (table 7) is considered valid only if the saturation index for calcite at the end of the flow path (table 8) indicates that the water is undersaturated with respect to calcite. The result generally is that more than one model can account for the chemical evolution of water from an initial to final composition because no single model represents a unique solution to the problem.

A fit of the measured data to a seemingly reasonable model does not prove that ground water is moving from the beginning to the end of the flow path. The model simply indicates that ground water at the end of the proposed flow path could have evolved chemically from the composition of water at the beginning of the path.

The first flow path evaluated is in the upper Maggie Creek Basin and involves ground-water flow from recharge areas in the Tuscarora Mountains to the discharge area along upper Maggie Creek. For this flow path, water from a spring adjacent to the Tuscarora Mountains (site 102; fig. 24) was chosen to represent the chemical composition of ground water near the recharge area. Although the spring orifice is in basinfill deposits, its flow originated as recharge in carbonate and clastic sedimentary rocks in the adjacent mountains (figs. 5 and 24). Water from a flowing well (site 41; fig. 24) was chosen to represent the chemical composition of ground water in the discharge area at the end of the flow path.

Ground-water flow lines shown in figure 22 indicate that the flow path described above is hydrologically reasonable. However, water from the spring is isotopically heavier than relatively deep ground water discharging from the well. The reason for this isotopic difference may be that water from the well originated as high-altitude recharge in northern parts of the basin. The isotopic difference, however, does not necessarily indicate that chemical differences between ground water near recharge areas in northern parts of the basin and ground water near recharge areas in southern parts are significant. Clastic sedimentary rocks structurally overlie carbonate rocks throughout the Tuscarora Mountains. For this reason, water discharging from the spring is thought to be chemically representative of ground water near recharge areas throughout the mountain range.

The mass-transfer model for the flow path from site 102 to site 41 (table 7) indicates that water from the flowing well at the end of the flow path could have evolved chemically from water at the spring near the recharge area in the southern Tuscarora Mountains. The composition would change by dissolving the minerals calcite, dolomite, pyrite, halite, andesine, and potassium feldspar and by exchanging dissolved calcium and magnesium with sodium on clays (table 7). Other phases are also chemically and thermodynamically feasible. For example, pyrite was chosen to represent the source of sulfate in the water in this model because of sulfide mineralization in the area; however, gypsum also is in rocks of the study area, and an acceptable model results if pyrite is replaced by gypsum. 
Tabie 7. Mass transfer of mineral and gas phases along four hypothetical ground-water flow paths in lower Maggie Creek area, northeastern Nevada

[Negative value indicates that phase is leaving solution as mineral precipitation, mineral formation, or outgassing; positive value indicates that phase is dissolving. For cation exchange, positive value indicates that sodium is entering solution and calcium and magnesium are being removed from solution. Symbol: --, constituent not used for mass-transfer calculation. Computed using computer program NETPATH (Plummer, and others, 1991)]

\begin{tabular}{|c|c|c|c|c|c|c|c|c|c|c|}
\hline \multirow{2}{*}{ Flow path ${ }^{1}$} & \multicolumn{2}{|c|}{ Carbonate minerais } & \multicolumn{4}{|c|}{ Aluminosilicate minerals } & \multicolumn{3}{|c|}{ Other phases } & \multirow{2}{*}{$\begin{array}{c}\text { Cation } \\
\text { exchange }\end{array}$} \\
\hline & Calclte & Dolomite & Andesine & Blotite & Kaollnlte & K-feldspar & Pyrite & Halite & $\begin{array}{c}\mathrm{CO}_{2} \\
\mathrm{gas}\end{array}$ & \\
\hline & \multicolumn{10}{|c|}{ Mass-transfer quantities (millimoles per kilogram of water) } \\
\hline 102 to 41 & 0.21 & 0.29 & 0.12 & -- & -- & 0.22 & 0.15 & 0.17 & 0.01 & 0.36 \\
\hline 102 to 106 & .26 & .42 & .64 & -- & -0.84 & .16 & .21 & .40 & 1.62 & -- \\
\hline 25 to 106 & .02 & -- & .03 & 0.00 & -- & -.01 & -.03 & -.03 & .40 & -.04 \\
\hline 102 and 25 & & & & -- & & & & & & \\
\hline to $106^{3}$ & .14 & .07 & .02 & & -- & .02 & .01 & .04 & .53 & -- \\
\hline
\end{tabular}

${ }^{1}$ Numbers are site numbers in tables 12-14 and figure 24. For first three flow paths, first number is site at beginning of flow path and second number is site at end of flow path. For last flow path, first two numbers are sites at beginning of flow path and third number is site at end of flow path.

${ }^{2}$ Exchange of calcium and magnesium for sodium is based on calcium-to-magnesium ratio in water at end of path.

${ }^{3}$ For this model, water from sites 102 and 25 was mixed to obtain composition of water at site 106.

Table 8. Saturation indices ${ }^{1}$ for mineral phases in ground water at ends of four hypothetical flow paths in lower Maggie Creek area, northeastern Nevada

[Calculated using computer program NETPATH (Plummer and others, 1991)]

\begin{tabular}{|c|c|c|c|c|c|c|c|}
\hline \multirow{2}{*}{$\begin{array}{l}\text { Slte No. } \\
\text { (flgure 24) }\end{array}$} & \multicolumn{2}{|c|}{ Carbonate mlnerals } & \multicolumn{4}{|c|}{ Aiuminoslllcate minerals } & \multirow{2}{*}{ Hallte } \\
\hline & Calcite & Dolomite & Albite & Anorthite & Biotite & Kaolinite & \\
\hline \multicolumn{8}{|c|}{ Recharge areas } \\
\hline 25 & -0.4 & -1.2 & 0.1 & -2.6 & -9.3 & 4.5 & -7.8 \\
\hline 102 & -2.2 & -4.8 & -1.1 & -3.0 & -15.1 & 5.6 & -8.9 \\
\hline \multicolumn{8}{|c|}{ Discharge areas } \\
\hline 41 & -0.3 & -0.9 & 0.3 & -2.6 & -4.6 & 3.2 & -8.0 \\
\hline 106 & -0.6 & -1.5 & -.4 & -3.1 & -9.8 & 4.1 & -7.9 \\
\hline
\end{tabular}

where SI is saturation index, IAP is ion-activity product, and $\mathrm{K}_{\mathrm{T}}$ is equilibrium constant at water temperature $\mathrm{T}$, for mineral of interest (Drever, 1988, p. 23). Positive value of SI indicates mineral can precipitate from solution; negative value indicates mineral can dissolve if present. Aluminum concentration of 10 micrograms per liter was used for calculations. 
The flow-path model discussed above may be representative of the chemical evolution of ground water between recharge areas in the Tuscarora Mountains and discharge areas near Maggie Creek. However, the model is not representative of the process if ground water near recharge areas in the northern part of the mountain range is not chemically similar to ground water near recharge areas in the southern part. This issue could be resolved by obtaining and analyzing other water-quality data for springs in the northern part of the mountain range. Such data are not available.

The second flow path evaluated involves groundwater flow from recharge areas in the southern Tuscarora Mountains and northern Marys Mountain to the discharge area at Carlin spring (from site 102 to site 106; table 7). The spring used to represent the chemistry of ground water near a recharge area for the first flow-path model also was used for this model for two reasons. First, ground-water flow lines extend from the southern Tuscarora Mountains to production wells near Gold Quarry (fig. 22). These flow lines probably extended to Carlin spring prior to development of the mine. Second, ground water near recharge areas on Marys Mountain could be chemically similar to ground water in recharge areas at the southern end of the Tuscarora Mountains because the same hydrogeologic units are in both areas (fig. 5). Phases used for this flow-path model were those used for the first model, except that the clay mineral kaolinite was allowed to form instead of using cation exchange. The reason for this change is that the increased residence time of water in the aquifer along the longer flow path could result in the formation of clay minerals. The model results for this flow path are similar to the results for the first flow path. However, amounts of mass transfer were greater for this longer flow path (tables 7 and 8 ).

The third flow path evaluated is shallow and extends from an irrigation well along lower Maggie Creek to Carlin spring (from site 25 to site 106; tables 7 and 8). The chemical composition of water at the well is assumed to be typical of recharge from Maggie Creek. Water at Carlin spring is assumed to be typical of water at the end of the flow path near the discharge area. Phases used for this model were the same as those used for the first flow-path model in the upper Maggie Creek Basin, except that biotite was used as a possible source of magnesium instead of dolomite because the ground water is moving through volcanic rocks. The model results indicate that pyrite, halite, and potassium feldspar should precipitate from the water, and sodium in solution should exchange for calcium and magnesium on clays (table 7). In contrast, saturation indices (table 8) indicate that ground water is undersaturated with respect to pyrite, halite, and potassium feldspar at both ends of the flow path. If present, these minerals should be dissolving. Thus, this model does not seem to be reasonable; however, the mass transfers involved in the formation of these minerals are very small (table 7), ranging from 0.01 to only $0.04 \mathrm{mmol} / \mathrm{kg}$. Such small amounts of mass transfer are within the uncertainties involved with the collection and analysis of the samples. The only phase involving more than $0.04 \mathrm{mmol} / \mathrm{kg}$ of mass transfer is carbon dioxide gas, which is probably being dissolved in the soil zone near Maggie Creek. This model suggests that water discharging from Carlin spring is chemically similar to water from the well next to Maggie Creek. This similarity is the result of minimal chemical reactions as the ground water moves rapidly through the volcanic rocks from Maggie Creek to Carlin spring. The tritium data discussed earlier also support this interpretation.

The fourth flow-path model involves ground water from two recharge sources: (1) recharge from the southern Tuscarora Mountains in the upper Maggie Creek Basin (site 102; fig. 24) and (2) infiltration of streamflow along lower Maggie Creek (site 25; fig. 24). Water from the two sources is mixed and discharges at Carlin spring (site 106; fig. 24). Mineral and gas phases for this model were calcite, dolomite, pyrite, halite, andesine, potassium feldspar, and carbon dioxide. The mixing of water from the two sources constitutes another phase in the model. The model results suggest that the composition of water at Carlin spring could have evolved from the two recharge sources by dissolution of the phases used in the model (tables 7 and 8).

The results of the fourth flow-path model also suggest that water discharging from Carlin spring could be a mixture of about 80 percent recharge from lower Maggie Creek and about 20 percent recharge from the southern end of the Tuscarora Mountains, northern end of Marys Mountain, Schroeder Mountain, and the unnamed hills. Total discharge of Carlin spring is an estimated 3,000 acre-ft/yr (see section titled "Surface Water"). Thus, as much as 2,000 acre- $\mathrm{ft} / \mathrm{yr}$ ( 80 percent) of the spring discharge may have originated as streamflow losses along Maggie Creek. 


\section{WATER BUDGETS}

Two types of water budgets for the study area are described in this section of the report. The first is a water-resources budget - a generalized budget that attempts to account for all of the water entering each basin and the mechanisms by which the water exits each of the basins. The second type of budget is more specific - it describes processes of ground-water recharge and discharge for each basin.

\section{Water-Resources Budgets}

Water-resources budgets for the Maggie, Marys, and Susie Creek Basins, and for the combined threebasin area are summarized in table 9 . The only known source of water for the three-basin area is precipitation; presently available hydrologic evidence indicates that ground-water underflow from basins beyond the study area is negligible. Water ultimately leaves the threebasin area as a result of evapotranspiration and runoff. A small fraction of precipitation infiltrates downward and becomes ground-water recharge. However, this ground water also eventually discharges as evapotranspiration or leaves the area as the baseflow part of runoff.

Annual precipitation for the three-basin area is an estimated 420,000 acre-ft/yr (table 9). Average runoff is estimated to be $38,000 \mathrm{acre}-\mathrm{ft} / \mathrm{yr}$ on the basis of annual flow differences between the Carlin and Palisade gaging stations on the Humboldt River for water years 1944-91 (see section titled "Surface Water"). The remaining 380,000 acre-ft of precipitation is consumed by evapotranspiration. If this amount of evapotranspiration is distributed over the combined area of the three basins ( 400,000 acres; table 5), the average, basin-wide evapotranspiration rate is about $1 \mathrm{ft} / \mathrm{yr}$. This includes areas of phreatophytes where water levels are shallow and areas where water levels are sufficiently deep that only soil moisture supports plant growth. The product of this rate and the area of each basin listed in table 5 was used to compute total evapotranspiration from each of the three basins for the water budgets (table 9).

Average annual precipitation for the Maggie Creek Basin is 270,000 acre-ft/yr (table 9). This is the only water entering the basin because underflow from the adjacent basins of Marys and Susie Creeks is negligible. Water leaves the basin as evapotranspiration, as runoff, as underflow to Marys Creek Basin, and as ground-water discharge to the Humboldt River channel. Total annual evapotranspiration in the basin is an estimated 250,000 acre-ft/yr, using the rate defined above and the basin area (254,000 acres; table 5). The average annual flow of Maggie Creek measured near its mouth during water years 1914-24 was 17,000 acre$\mathrm{ft} / \mathrm{yr}$. For reasons stated previously, this value is also thought to be a reasonable estimate of a long-term average flow from the basin. Ground-water underflow to Marys Creek Basin is estimated to be at least 3,000 acre- $\mathrm{ft} / \mathrm{yr}$. Ground-water discharge from Maggie Creek Basin that supports baseflow of the Humboldt River has not been measured but is assumed to be included as a part of total runoff from the three-basin area. Thus, the minimum amount of water leaving the Maggie Creek Basin is an estimated 270,000 acre-ft/yr

Water enters the Marys Creek Basin as precipitation and as ground-water underflow from the Maggie Creek Basin. Total annual precipitation is an estimated 30,000 acre- $\mathrm{ft} / \mathrm{yr}$, and underflow is estimated to be at least 3,000 acre-ft/yr. Total inflow to the basin is an estimated 33,000 acre-ft/yr. Water leaves the basin as evapotranspiration, runoff, spring discharge, and inflow to the river channel. Using the rate defined above, annual evapotranspiration is an estimated 30,000 acre- $\mathrm{ft} / \mathrm{yr}$. Average runoff from the basin is at least 3,000 acre-ft/yr (approximately equivalent to Carlin springflows, $4 \mathrm{ft}^{3} / \mathrm{s}$ ), but will vary from year to year depending on the snowmelt runoff. Ground-water discharge supporting baseflow of the river has not been measured but is assumed to be included as a part of the value of total runoff from the three-basin area. Thus, the minimum amount of water leaving the Marys Creek Basin is estimated to be at least 33,000 acre- $\mathrm{ft} / \mathrm{yr}$.

The major source of water to the Susie Creek Basin is precipitation, which is an estimated 120,000 acre-ft/yr. Ground-water underflow from upper Maggie Creek Basin to the west and other basins to the east is negligible. Water leaves the basin as evapotranspiration, runoff, and inflow to the river channel. Total annual evapotranspiration is an estimated 117,000 acre- $\mathrm{ft} / \mathrm{yr}$, using the rate defined above and the basin area listed in table 5. Annual runoff from the entire basin has not been quantified; however, a total annual flow of more than 4,000 acre- $\mathrm{ft} / \mathrm{yr}$ was recorded at a gaging station about 15 mi upstream from the mouth during water years 1956-1958 (U.S. Geological Survey, 1963, p. 250). Thus, total annual runoff from the basin is believed to be 4,000-5,000 acre-ft/yr. Groundwater discharge from Susie Creek Basin that supports 
Tabie 9. Long-term water-resources budgets for study area, northeastern Nevada

[Values, in acre-feet per year. Individual budget elements rounded to nearest 1,000; totals rounded to two significant figures. Abbreviations: --, not applicable; acre-ft/yr, acre-feet per year; $\mathrm{ft}^{3} / \mathrm{s}$, cubic feet per second]

\begin{tabular}{|c|c|c|c|c|}
\hline Item & Maggie Creek & Marys Creek & Susie Creek & $\begin{array}{l}\text { Total for } \\
\text { three-baein } \\
\text { study area }\end{array}$ \\
\hline \multicolumn{5}{|c|}{ Inflows } \\
\hline Total precipitation ${ }^{2}$ & 270,000 & 30,000 & 120,000 & 420,000 \\
\hline $\begin{array}{l}\text { Ground-water underflo } \\
\text { from basins: } \\
\text { In study area } \\
\text { Beyond study area }\end{array}$ & $\begin{array}{l}0 \\
0\end{array}$ & $\begin{array}{r}3,000 \\
0\end{array}$ & $\begin{array}{l}0 \\
0\end{array}$ & $\overline{0}$ \\
\hline Total inflow & 270,000 & 33,000 & 120,000 & 420,000 \\
\hline \multicolumn{5}{|c|}{ Outflows } \\
\hline Evapotranspiration 4 & 250,000 & 30,000 & 117,000 & 5380,000 \\
\hline Stream runoff & ${ }^{6} 17,000$ & 73,000 & ${ }^{8} 4,000-5,000$ & ${ }^{9} 38,000$ \\
\hline $\begin{array}{l}\text { Ground-water underflo } \\
\text { to basins: } \\
\text { In study area } \\
\text { Beyond study area }\end{array}$ & $\begin{array}{r}10,000 \\
0\end{array}$ & $\begin{array}{l}0 \\
0\end{array}$ & $\begin{array}{l}0 \\
0\end{array}$ & $\begin{array}{l}0 \\
0\end{array}$ \\
\hline \multicolumn{5}{|c|}{ Water use ${ }^{11}$} \\
\hline Streamfiow diversions & $4,000-5,000$ & ${ }^{12} 1,200$ & 0 & $5,000-6,000$ \\
\hline Pumpage & ${ }^{13} 7,000-8,000$ & 0 & 0 & $7,000-8,000$ \\
\hline Total outflow ${ }^{14}$ & ${ }^{15} 270,000$ & 1533,000 & ${ }^{15} 120,000$ & 420,000 \\
\hline \multicolumn{5}{|c|}{${ }^{1}$ Totals may not equal sum of three basins because of rounding. } \\
\hline \multicolumn{5}{|c|}{${ }^{2}$ Basin values computed from areas of altitude zones and annual precipitation for each zone listed in table 5.} \\
\hline \multicolumn{5}{|c|}{${ }^{4}$ Values computed from basin-wide rate of 1 foot per year and basin areas listed in table 5.} \\
\hline \multicolumn{5}{|c|}{${ }^{5}$ Value computed as difference between total precipitation and runoff. } \\
\hline \multicolumn{5}{|c|}{$\begin{array}{l}{ }^{7} \text { Minimum value based on estimated flow of Carlin spring }\left(4 \mathrm{ft}^{3} / \mathrm{s}\right) \text {. Includes about } 600-700 \text { acre- } \mathrm{ft} / \mathrm{yr} \text { diverted } \\
\text { vn of Carlin. }\end{array}$} \\
\hline \multicolumn{5}{|c|}{$\begin{array}{l}{ }^{8} \text { Range of values based on 3-year record at gaging station about } 15 \text { miles upstream from the mouth (U.S. Geo- } \\
\text { logical Survey, 1963, p. 250). }\end{array}$} \\
\hline \multicolumn{5}{|c|}{$\begin{array}{l}{ }^{9} \text { Long-term gain in annual flow of Humboldt River between Carlin and Palisade gaging stations. Value includes } \\
\text { low due to ground-water discharge to river channel and springflow. }\end{array}$} \\
\hline \multicolumn{5}{|c|}{${ }^{10}$ Estimated underflow to Marys Creek basin. } \\
\hline \multicolumn{5}{|c|}{${ }^{11}$ Values not included as part of total basin outflows, because most eventually is lost as evapotranspiration. } \\
\hline \multicolumn{5}{|c|}{${ }^{12}$ Includes about 600 acre-ft/yr diverted for Carlin and 600 acre-ft/yr for agriculture. } \\
\hline \multicolumn{5}{|c|}{13 Includes about 6,000 acre-ft/yr for mining in 1990 (table 4) and 1,800 acre-ft/yr or less for agriculture. } \\
\hline${ }^{14}$ Totals do not incluc & for water use. & & & \\
\hline
\end{tabular}


baseflow of the Humboldt River has not been measured but is assumed to be included as a part of the value of total runoff from the three-basin area. The minimum amount of water leaving the Susie Creek Basin is an estimated $120,000 \mathrm{acre}-\mathrm{ft} / \mathrm{yr}$.

Estimated evapotranspiration and precipitation are the largest parts of each budget presented above. The errors in each of these budget elements may exceed the total estimates for other parts of each budget. In addition, the sum of estimated runoff from the three basins (table 9) is only 24,000-25,000 acre-ft. This is far short of the measured runoff from the threebasin area, which is 38,000 acre- $\mathrm{ft} / \mathrm{yr}$ (table 9). To resolve this discrepancy, runoff values for each basin need to be measured under conditions of normal precipitation.

\section{Ground-Water Budgets}

Ground-water budgets for the study area are listed in table 10. Budgets are shown for the basins of upper and lower Maggie Creek, the entire basins of Maggie, Susie, and Marys Creeks, and the combined three-basin area. Budget imbalances can be accounted for either as errors in one or more of the estimates or, if estimated recharge exceeds estimated discharge, as potential recharge that instead leaves the basin as runoff. In addition, estimates of discharge are believed to be more reliable because the values for evapotranspiration, seepage, and springflow are based on field measurements. In contrast, estimates of potential recharge are empirically derived.

The water budget for the basin of Maggie Creek is separated into budgets for the upper and lower parts of the basin because the two differ hydrologically. Together, these two budgets and the budget for the entire Maggie Creek Basin provide a better understanding of the movement of ground water and interactions of ground water and surface water than the entirebasin budget would alone.

The basin of upper Maggie Creek is the main recharge area for the entire basin, and potential recharge as infiltration of precipitation, including infiltration of streamflow near mountain fronts, is an estimated 16,000 acre-ft/yr. Underflow of ground water from adjacent basins and infiltration of upper Maggie Creek streamflow are negligible. Thus, total recharge is an estimated 16,000 acre- $\mathrm{ft} / \mathrm{yr}$.
Ground water discharges from upper Maggie Creek Basin as evapotranspiration (7,100 acre-ft/yr), as inflow to upper Maggie Creek (4,000 acre-ft/yr), and as a small amount of underflow through Schroeder Mountain to the lower basin (less than 1,000 acre-ft/yr). Total estimated discharge is about 12,000 acre- $\mathrm{ft} / \mathrm{yr}$. The budget imbalance between estimated recharge and discharge is about 4,000 acre-ft/yr (table 10).

Ground water is recharged in the basin of lower Maggie Creek as infiltration of precipitation (990 acre$\mathrm{ft} / \mathrm{yr})$, as infiltration of streamflow (7,000 acre-ft/yr), and as underflow from upper Maggie Creek Basin (less than 1,000 acre-ft/yr). Total estimated recharge is about 9,000 acre-ft/yr.

Ground water discharges from the lower Maggie Creek Basin as evapotranspiration (1,900 acre- $\mathrm{ft} / \mathrm{yr})$, as an unquantified amount of inflow into the channels of Maggie Creek near its mouth and the Humboldt River, and as underflow through volcanic rocks and basin-fill deposits to the Marys Creek Basin (3,000 acre-ft/yr). Total discharge is estimated to exceed 5,000 acre-ft/yr. The budget imbalance between estimated recharge and discharge is about 4,000 acre-ft/yr (table 10).

For the entire basin of Maggie Creek, groundwater recharge from infiltration of precipitation is an estimated 17,000 acre-ft/yr. Ground-water discharge as evapotranspiration is about 9,000 acre- $\mathrm{ft} / \mathrm{yr}$, and as underflow to Marys Creek Basin is about 3,000 acre$\mathrm{ft} / \mathrm{yr}$. Inflow to the channel of the Humboldt River could not be quantified. Total discharge is estimated to exceed 12,000 acre-ft/yr. The budget imbalance of about 5,000 acre- $\mathrm{ft}$ (table 10) includes errors in estimation and components of discharge that have not been fully quantified.

Three items in the budgets for the basins of upper and lower Maggie Creek are not included in the budget for the entire basin. These items are ground-water discharge to upper Maggie Creek (4,000 acre- $\mathrm{ft} / \mathrm{yr})$, underflow between the two basins (about 1,000 acre$\mathrm{ft} / \mathrm{yr}$ ), and infiltration of streamflow along lower Maggie Creek (7,000 acre-ft/yr). The reason is that the three items represent movement of water between the upper and lower basins of Maggie Creek. They are not sources of recharge to or discharge from the basin as a whole.

Ground water is recharged to Marys Creek Basin as infiltration of precipitation (1,300 acre-ft/yr) and as underflow from lower Maggie Creek Basin (at least 3,000 acre-ft/yr). Total estimated recharge is about 4,000 acre-ft/yr. Ground water discharges as 
Table 10. Long-term ground-water budgets for study area, northeastern Nevada

[All values in acre-feet per year. Basin totals are rounded to nearest 1,000. Symbol: --, not measured or not applicable. Abbreviation: $\mathrm{ft}^{3} / \mathrm{s}$, cubic feet per second]

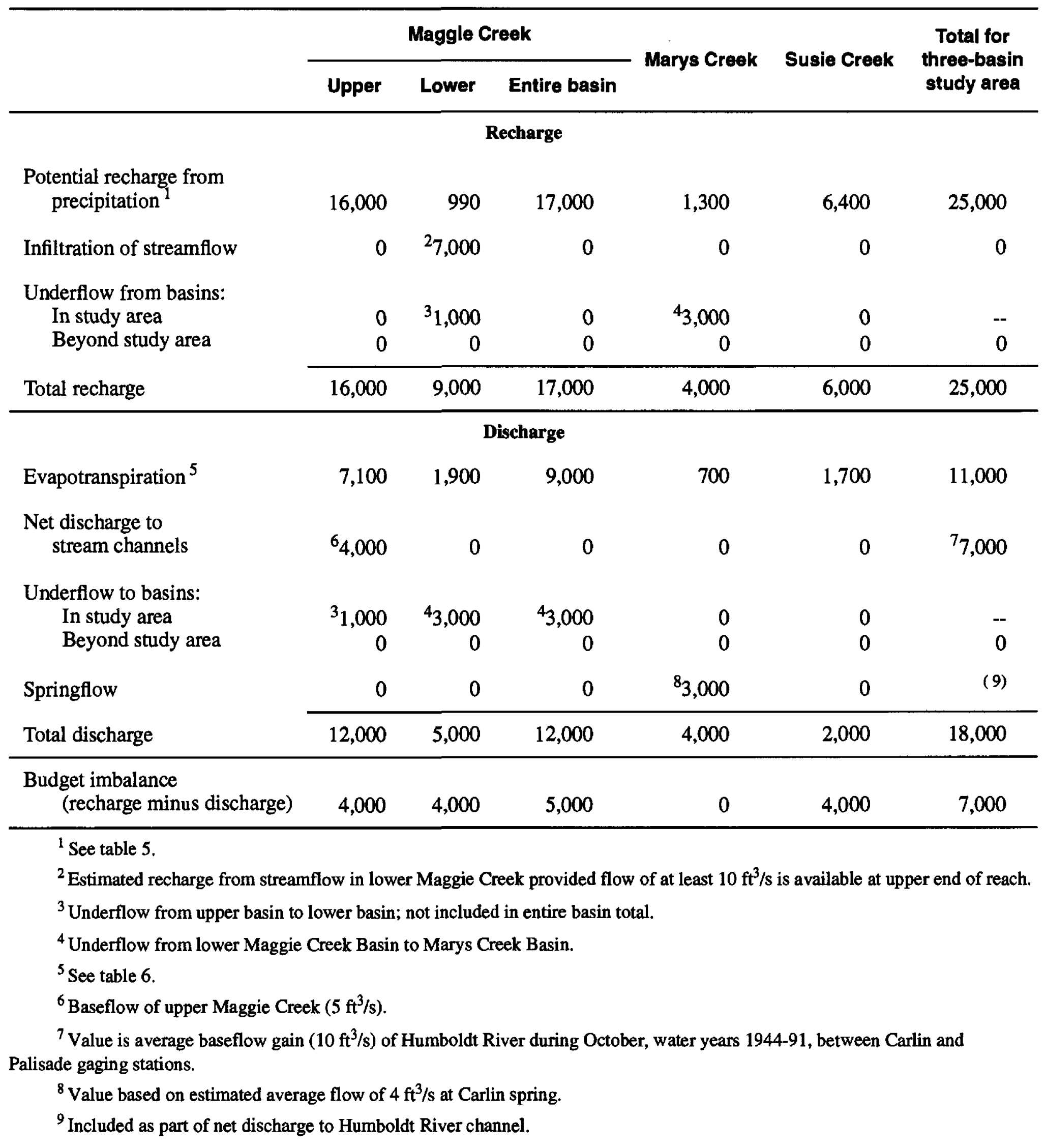

evapotranspiration (700 acre-ft/yr), as flow of Carlin spring $(3,000$ acre- $\mathrm{ft} / \mathrm{yr})$, and as an unquantified amount of inflow to the channels of Marys Creek below Carlin spring and the Humboldt River. Total estimated discharge is about 4,000 acre- $\mathrm{ft} / \mathrm{yr}$. Estimated recharge and discharge are about the same (table 10). However, these estimates have uncertainties that are common to the same estimates for other basins in the study area.
Ground-water recharge to the Susie Creek Basin as infiltration of precipitation is an estimated 6,400 acre-ft/yr. Ground-water discharge as evapotranspiration is an estimated 1,700 acre-ft/yr. Groundwater discharge as inflow to the channel of the Humboldt River cannot be quantified. Total estimated discharge exceeds 2,000 acre-ft/yr. The budget imbalance between estimated recharge and discharge is 
4,000 acre-ft/yr (table 10) and can be accounted for, in part, as the unquantified discharge to the Humboldt River channel.

The combined area of Maggie, Marys, and Susie Creek Basins receives an estimated 25,000 acre-ft/yr of recharge as infiltration of precipitation. Ground-water discharge as evapotranspiration is an estimated 11,000 acre-ft/yr, and the total inflow to the river channel and nearby springflow is an estimated $7,000 \mathrm{acre}-\mathrm{ft} / \mathrm{yr}$, for a total estimated discharge of $18,000 \mathrm{acre}-\mathrm{ft} / \mathrm{yr}$. The budget imbalance is 7,000 acre- $\mathrm{ft} / \mathrm{yr}$ (table 10).

The principal reason for the budget imbalance may be that recharge from infiltration of precipitation is overestimated. The potential ground-water recharge included in this overestimate could be part of the annual snowmelt runoff. In addition, ground-water discharge to the Humboldt River channel $(7,000$ acre$\mathrm{ft} / \mathrm{yr}$ ) could be underestimated. The value for this budget element is based on comparison of the longterm records at two stream gaging stations and on the minimum gains in streamflow measured during the study. The actual value could be more than $7,000 \mathrm{acre}-\mathrm{ft} / \mathrm{yr}$.

\section{CONCEPTUAL MODEL OF HYDROLOGIC SYSTEM IN LOWER MAGGIE CREEK AREA}

A conceptual model is a clear, qualitative, physical picture of how a natural system operates (Franke and others, 1987, p. 1). In the context of this definition, the conceptual model of the hydrologic system in the lower Maggie Creek area includes hydrologic boundaries, the different hydrogeologic units that make up the system, the hydraulic properties of the units, sources and locations of ground-water recharge, locations and processes of ground-water discharge, directions of ground-water movement, and interactions of streams and aquifers. Each of these parts has been defined in preceding sections of this report. In this section of the report, the different components of the hydrologic system in the lower Maggie Creek area are brought together and presented as a conceptual model (fig. 28).

The shallow hydrologic system in the lower Maggie Creek area has several types of boundaries. Impermeable or poorly permeable rocks, which may include all of the hydrogeologic units that compose bedrock, form the lateral boundaries. These boundaries coincide with the Tuscarora Mountains and Marys Mountain to the west and the Adobe Range to the east. The Independence Mountains and bedrock of the unnamed hills northeast of the Maggie Creek canyon form an impermeable boundary between upper Maggie Creek Basin and Susie Creek Basin. The unnamed hills also form an impermeable boundary between the upper and lower Maggie Creek Basins. However, the bedrock of Schroeder Mountain is permeable and allows a minimal amount of ground-water flow between the upper and lower Maggie Creek Basins. Topographic divides between the lower Maggie, Marys, and Susie Creek Basins do not form ground-water divides. Groundwater flow in this part of the study area is across the three basins. The southern boundary is the Humboldt River, which is the destination (a line sink) of groundwater flow.

The boundary of the Maggie Creek flow system at depth is not well defined. Also, limited evidence indicates the presence of deep ground-water flow in addition to shallow flow. Evidence for deep flow includes hot springs in the Adobe Range and along the channel of the Humboldt River, a geothermal well at Carlin, and thermal water in deep wells at Gold Quarry mine. Depths to which thermal water circulates in the study area and the boundary between shallow and deep flow also are uncertain. Shallow flow over much of the study area may be mostly in basin-fill deposits and in shallow bedrock such as at Schroeder Mountain (figs. 22 and 28). Deep flow may be mostly in bedrock beneath structural basins.

The upper boundary of ground-water flow in the lower Maggie Creek area may be mostly represented by water-table conditions. Upward gradients have been verified only in the southern part of the upper Maggie Creek Basin (fig. 22); however, these gradients are a result of the effects of poorly permeable bedrock of the unnamed hills northeast of the Maggie Creek canyon rather than confining beds in the basin-fill aquifer. Upward gradients between bedrock and overlying basin-fill deposits have been identified at wells recently drilled near Gold Quarry mine (C.J. Zimmerman, oral commun., 1992).

Ground water in the upper Maggie Creek Basin moves from recharge areas in the Tuscarora Mountains and Independence Mountains, toward Maggie Creek (figs. 22 and 28) and then southward along the axis of the basin. Ground water discharges as evapotranspiration in lowlands along the flood plain and as inflow to the stream channel that sustains the baseflow of upper 
A

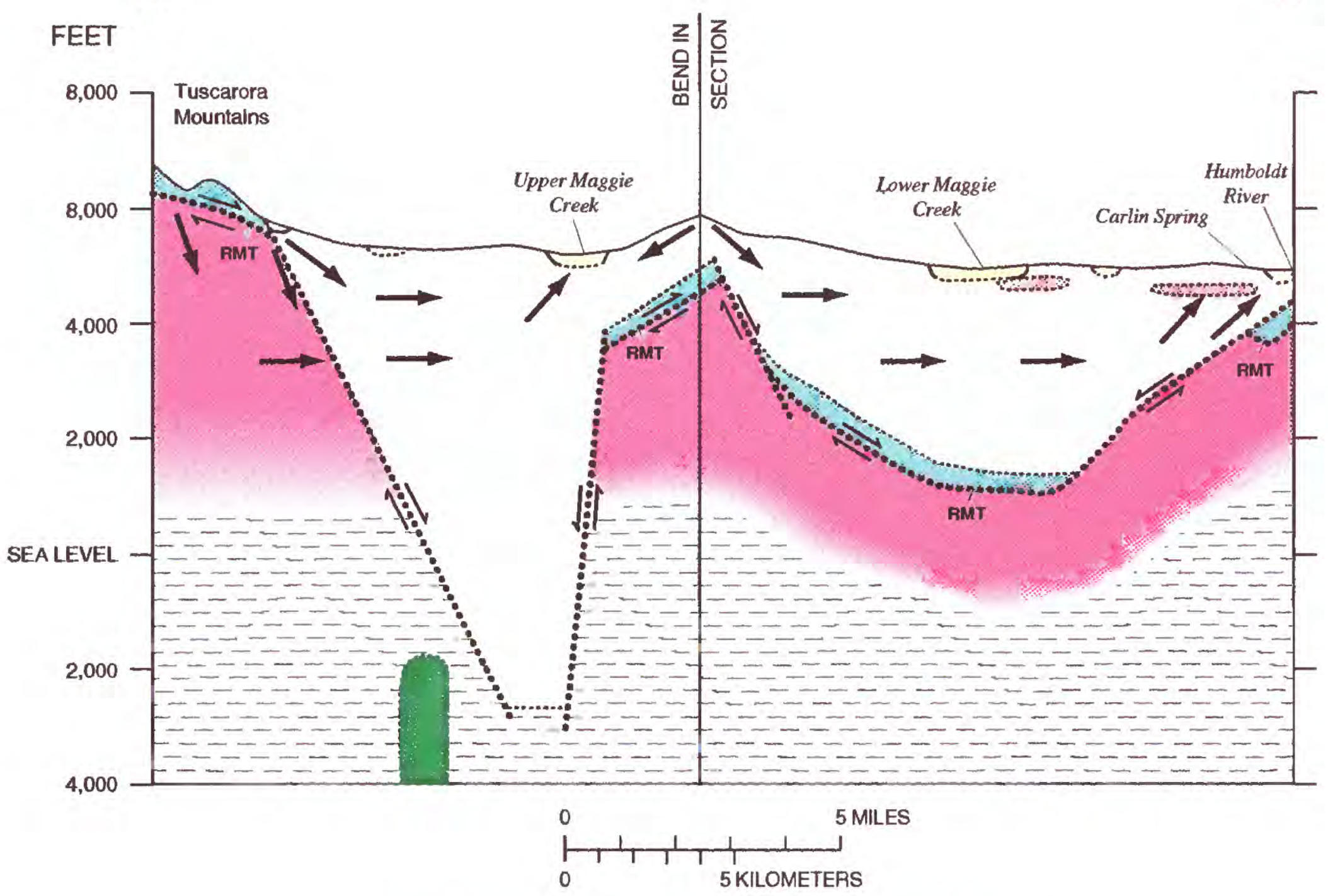

VERTICAL EXAGGERATION APPROXIMATELY X5

\section{EXPLANATION}

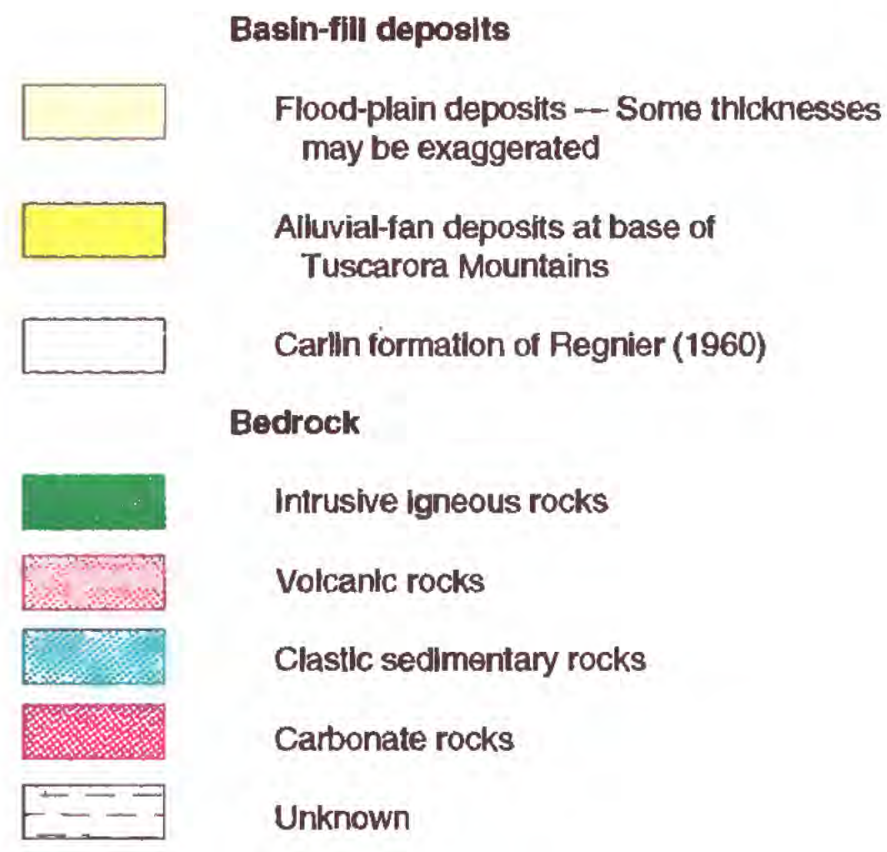

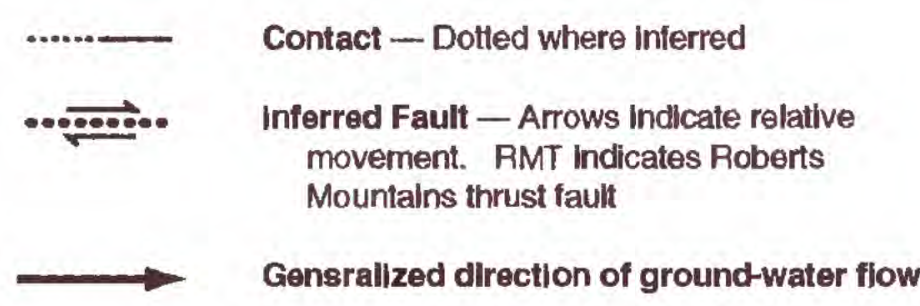

Figure 28. Conceptual hydrogeologic section A-A' in lower Maggie Creek area, northeastern Nevada (see figure 5 for section location). Surficial geology is from figure 5 ; configuration of contact between bedrock and basin fill and position of intrusive igneous rocks are from figure 14; positions of faults, including Roberts Mountain thrust, are inferred. 
Maggie Creek. Baseflows leave the basin by way of upper Maggie Creek and enter the lower Maggie Creek Basin. Ground water moves through fractured bedrock of Schroeder Mountain to the lower Maggie Creek Basin (fig. 22). The extent of deep ground water in carbonate rocks is uncertain (fig. 28).

Ground water in the lower Maggie Creek, Marys Creek, and Susie Creek Basins generally moves southward and eastward from recharge areas to the main discharge area along the Humboldt River (figs. 22 and 28). Ground water is recharged by infiltration of precipitation on Marys Mountain and the Independence Mountains, by leakage of streamflow from Maggie Creek, and by a small amount of underflow from the upper Maggie Creek Basin. The only other underflow in this part of the study area is through volcanic rocks and basin-fill deposits from lower Maggie Creek Basin to Marys Creek Basin. Ground water discharges as evapotranspiration, as springflow, and as inflow directly to the Humboldt River channel, which is the regional sink for ground-water flow.

\section{MEASURED AND POTENTIAL EFFECTS OF PUMPING}

Water-level changes in the lower Maggie Creek area from March 1989 to September 1990 consisted mostly of declines, although water levels did rise, but less than $1 \mathrm{ft}$, at two wells (fig. 29 and table 13). Some of the declines, especially those exceeding $10 \mathrm{ft}$, are due mostly to pumping at Gold Quarry mine. The largest decline recorded was $41 \mathrm{ft}$ at a well finished in carbonate rocks on the west side of Schroeder Mountain. This well may be hydraulically connected, by way of fractured bedrock along a fault, to the east side of Schroeder Mountain where high-yield production wells penetrate carbonate and clastic sedimentary rocks.

A third consecutive year of drought also contributed to the water-level declines in 1989-90. The effects of the drought are most apparent along stream flood plains. The largest water-level decline related to the effects of the drought was $10 \mathrm{ft}$, in a well along lower Maggie Creek (well 11; table 13, fig. 29). The water level in this well responds rapidly to changes in Maggie Creek streamflow (see section titled "Ground Water").

Long-term pumping of ground water at the Gold Quarry mine, on the flank of Schroeder Mountain, will affect water resources in the lower Maggie Creek area in two ways. First, ground-water levels will decline over an area, the eventual extent of which will depend on the distribution of pumping and on the nature of the hydraulic connection between bedrock of Schroeder Mountain and adjoining basin-fill deposits. Second, the flow of Maggie Creek will change in response to changes in ground-water levels at Schroeder Mountain and to discharge of water from the pit into the stream channel farther downstream.

Pumping for dewatering at Gold Quarry mine may continue for as long as the mine operates. Initial pumping rates required for dewatering are 5,000-10,000 acre- $\mathrm{ft} / \mathrm{yr}$ and could increase to a maximum rate of about 70,000 acre- $\mathrm{ft} / \mathrm{yr}$ around the year 2000 (C.J. Zimmerman, oral commun., 1993).

Water not needed for mining and milling is stored in a reservoir on the east side of the unnamed hills northeast of the Maggie Creek canyon (fig. 2). Part of this water is used to irrigate crops and pastures, part may leak through the reservoir floor back into the ground-water system, part of it evaporates, and some is released into the channel of lower Maggie Creek. An estimated 60,000 acre-ft/yr may have to be released into Maggie Creek during the late stages of dewatering (C.J. Zimmerman, oral commun., 1993). This amount of water is more than twice the estimated annual ground-water recharge to the combined area of the Maggie, Marys, and Susie Creek Basins (table 10). The amount leaving the basin as runoff will be proportionately less if leakage from the reservoir is appreciable.

Water-level declines resulting from dewatering of the Gold Quarry mine initially will be in carbonate and clastic sedimentary rocks of Schroeder Mountain. As mining and consequent pumping extend deeper and fractures in these rocks are drained, any of several situations could develop with regard to water levels in basin-fill deposits beyond Schroeder Mountain and to flow of Maggie Creek.

A combination of hydrologic, geochemical, and water-budget evidence indicates that only small amounts of ground water move through sedimentary rocks of Schroeder Mountain between the upper and lower Maggie Creek Basins. If this conclusion is correct, then water-level declines may be restricted mostly to the sedimentary rocks and extend only short distances into basin-fill deposits of adjoining parts of upper and lower Maggie Creek Basins.

Faults in the carbonate and clastic sedimentary rock of Schroeder Mountain and the unnamed hills may function as either barriers to or conduits for groundwater flow. Thus, water-level declines in the Schroeder 


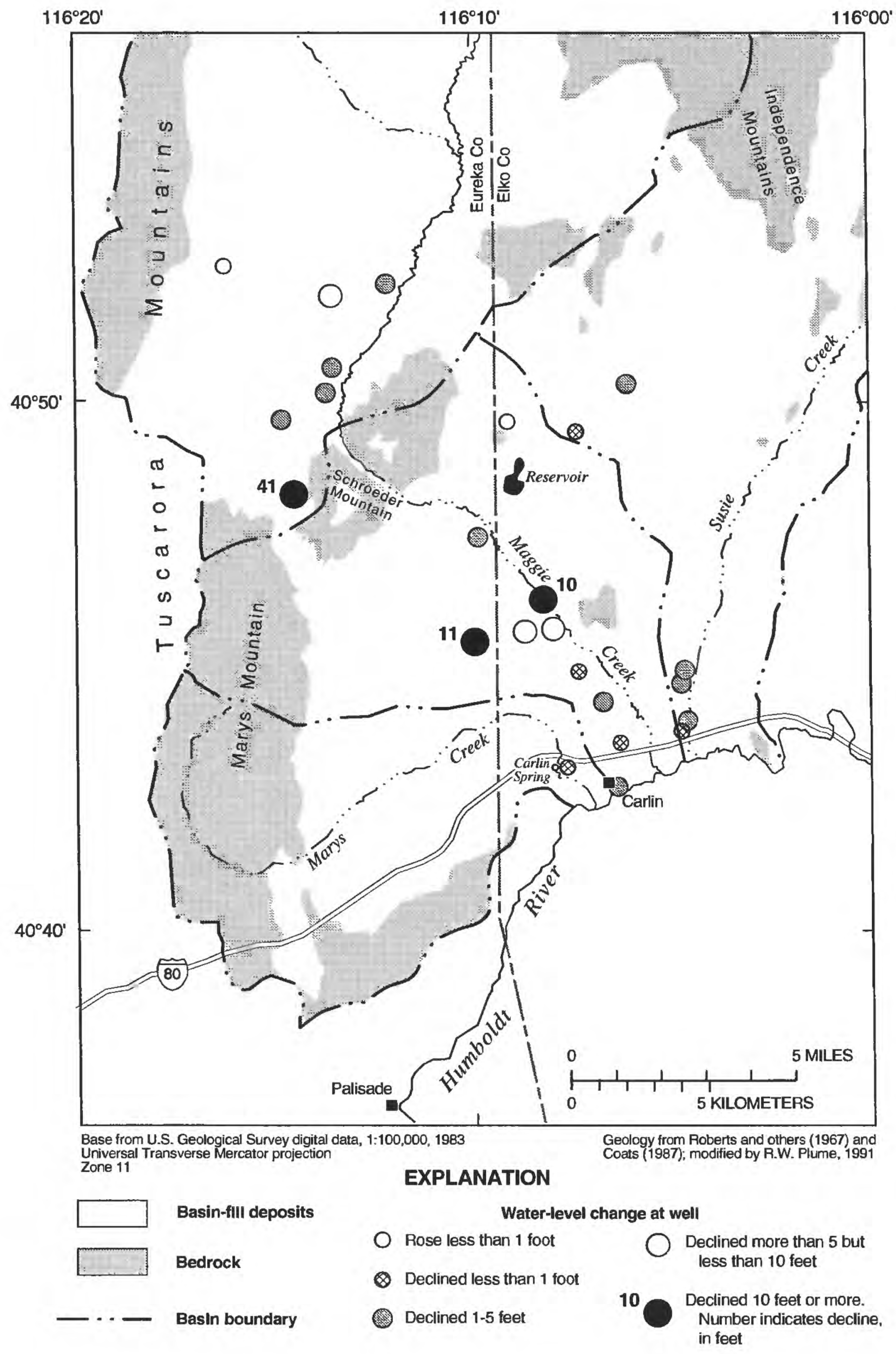

Figure 29. Wells in lower Maggie Creek area, northeastern Nevada, where water-level changes were measured, March 1989 - September 1990. 
Mountain uplift eventually could be extensive or restricted to relatively small fault-bounded areas. If the sedimentary rocks of Schroeder Mountain prove to be hydraulically connected to adjacent basin-fill deposits, water-level declines in the deposits could extend appreciable distances to the south, east, and northwest of Schroeder Mountain. In addition, dewatering eventually could result in reduced hydraulic heads in bedrock where it is overlain by basin-fill deposits in areas northwest and southeast of Schroeder Mountain. Reduced heads in bedrock could induce water-level declines in the overlying basin-fill aquifer. Water levels will begin to recover once pumping ceases; however, the time required for complete recovery is not known.

Streamflow of Maggie Creek also is expected to be affected by the dewatering of sedimentary rocks at Schroeder Mountain. Maggie Creek in the canyon at Schroeder Mountain (sites MC-1 to MC-3; fig. 16) has been a losing reach under most conditions of flow measured during the past few years (table 11). The flow of Maggie Creek at site MC-3 ceased in late summer 1991 for the first time since the study began in August 1988. This effect was probably the result of both the testing of dewatering wells at Gold Quarry mine and the continuing drought.

The extent of upper Maggie Creek eventually affected by dewatering of Schroeder Mountain will depend on the response of ground-water levels in basin-fill deposits adjacent to the mountain. If water levels decline over only a small area, then the effect on the flow of upper Maggie Creek should be minimal. If water-level declines are appreciable, upper Maggie Creek in the reach adjacent to the unnamed hills could cease to flow except during the snowmelt runoff.

Releases from the reservoir during dewatering would maintain the flow of lower Maggie Creek, ensuring that the stream would continue to be a source of recharge to the lower Maggie Creek Basin. This recharge would continue as long as reservoir releases to Maggie Creek exceed the capacity of the stream channel to transmit water to the underlying aquifer. Excess flow would leave the basin as runoff to the Humboldt River. Once dewatering ceases, most of the flow of upper Maggie Creek, except for snowmelt runoff, would be captured at Schroeder Mountain at the cone of depression created by dewatering. The result probably would be that lower Maggie Creek would flow only during the snowmelt runoff. Thus, ground-water recharge from infiltration of lower Maggie Creek streamflow to the underlying aquifer may be greatly reduced once dewatering of Gold Quarry mine ceases. This could eventually result in reduced flow of Carlin spring. Reduced flows of Maggie Creek also could reduce the flows of the Humboldt River and eventually affect downstream water rights.

Reservoir releases to lower Maggie Creek would increase the magnitude of average flows outside the normal snowmelt-runoff period and, thus, may increase bank erosion and sediment transport by the stream. Part of the sediment would enter the Humboldt River. Part also would be deposited along the channel of lower Maggie Creek where the stream gradient decreases near the edge of the Humboldt River flood plain. However, evaluation of the hydrodynamics of lower Maggie Creek was beyond the scope of this study.

\section{POTENTIAL FOR ARTIFICIAL RECHARGE}

Artificial recharge could help offset water-level declines and reduced streamflow expected to result from pumping of ground water at Gold Quarry mine. Use of recharge wells was not considered to be a feasible approach for artificial recharge for two reasons (C.J. Zimmerman, Newmont Gold Go., oral commun., 1991). First, basin-fill deposits were not believed to be sufficiently permeable. A large number of recharge wells would be required for reinjection of water into the basin-fill aquifer. Second, reinjection of water into permeable bedrock could create conditions whereby the water would circulate between recharge wells and dewatering wells.

Snowmelt runoff from the basin of Maggie Creek could be available as a source of artificial recharge in the lower Maggie Creek area. This runoff from the basin could be used as a source of recharge in two ways. First, runoff could be impounded in Maggie Creek canyon at Schroeder Mountain. Second, water from the impoundment could be released into the stream channel and one or more open ditches in the lower Maggie Creek Basin.

The Maggie Creek canyon was considered as a potential dam site in 1963 (Sax, 1963, p. 64). The dam was proposed to be used for flood control, recreation, and storage of water for irrigation. Estimated storage was 5,000 acre-ft behind a dam $50 \mathrm{ft}$ high and $900 \mathrm{ft}$ long (Sax, 1963, p. 64). As far as is known, feasibility studies for the site were never made. Although a dam at the site now could serve those uses, its main purpose 
would be to enhance ground-water recharge where water levels are expected to decline in response to long-term dewatering of Gold Quarry mine. Such a project could begin no earlier than the late stages of dewatering; otherwise, the infiltration of impounded water to underlying aquifers would contribute to the dewatering problem at the mine.

The capacity of the channel of Maggie Creek and carbonate and clastic sedimentary rocks at Maggie Creek canyon to transmit impounded water is not well defined. However, this reach of the stream has been a losing reach under most conditions of flow (sites MC-1, MC-2, and MC-3; fig. 16 and table 11). Continued streamflow measurements made over this reach of Maggie Creek would better define the capacity of the stream channel to transmit water to the underlying aquifer.

Another advantage of impounding water in the Maggie Creek canyon would be that releases of water to lower Maggie Creek could be controlled. As long as water was available and downstream uses were not affected, controlled releases could take full advantage of the capacity of the channel of lower Maggie Creek to transmit water to the underlying aquifer.

\section{SUMMARY}

A hydrologic study of the Maggie Creek area in northeastern Nevada began in August 1988 in response to concern over possible effects of ground-water pumping at the Gold Quarry mine near Maggie Creek. Pumpage at the mine increased from 790 acre-ft in 1985 to more than 6,000 acre-ft in 1990. In 1993, pit dewatering began, and the pumping rate may gradually increase to about 70,000 acre-ft/yr near the end of dewatering, in about the year 2000. Specific concerns over possible effects of long-term pumping at the mine include changes in the flow of Maggie Creek and the Humboldt River, declining ground-water levels over large areas, and reduced flow of Carlin spring-the historical water supply for the town of Carlin.

Seven hydrogeologic units, ranging in age from Cambrian to Quaternary, underlie the Maggie Creek area as bedrock and basin-fill deposits. Bedrock consists of carbonate rocks of Cambrian to Devonian age; clastic sedimentary rocks of Ordovician, Silurian, and Devonian age; volcanic rocks of Jurassic and late Eocene or Oligocene to Miocene age; and intrusive rocks of late Eocene or Oligocene age. Bedrock forms mountain ranges and structural basins in which basinfill deposits, thousands of feet thick, have accumulated.

Maggie Creek consists of two reaches with differing baseflow characteristics. The upper reach gains flow as a result of ground-water discharge to the stream channel in the area near the unnamed hills northeast of the Maggie Creek canyon. Long-term minimum baseflow of this reach of the stream is an estimated $5 \mathrm{ft}^{3} / \mathrm{s}$.

The lower reach of Maggie Creek, from Schroeder Mountain to the Humboldt River, consistently loses flow that infiltrates the stream channel and recharges the underlying aquifer. This reach is dry from mid-summer to early fall.

Total flows in water years 1990-91 at two gaging stations on lower Maggie Creek-one at the mouth of Maggie Creek canyon, and the other about $5 \mathrm{mi}$ downstream-were 8,100 and 5,400 acre-ft, respectively, at the upper station and 4,200 and 1,400 acre-ft, respectively, at the lower station. Flow losses as infiltration through the stream channel during both years were about 4,000 acre-ft.

Comparison of flow measurements made at the upper gaging station with measurements made at a site near the stream mouth indicates that potential streamflow infiltration rates through the channel of lower Maggie Creek are $10-20 \mathrm{ft}^{3} / \mathrm{s}$. This infiltration of streamflow could provide at least 7,000 acre-ft/yr of recharge to the aquifer in the lower Maggie Creek Basin, provided sufficient flows are available at the upper gaging station.

At a site near its mouth, peak flows of Maggie Creek in water years 1914-24 ranged from 100 to 800 $\mathrm{ft}^{3} / \mathrm{s}$ during the snowmelt runoff. However, little or no flow was measured in middle to late summer and fall during the period. Total annual flows ranged from about 3,000 acre-ft in 1924 to about 34,000 acre-ft in 1914. The average annual flow for the period was 17,000 acre-ft.

Over most of its length, Marys Creek flows only during the snowmelt runoff and intense storms. The lower mile of the stream flows continuously as a result of the discharge of Carlin spring. Total flow of Marys Creek below the spring, from November 18, 1989, to September 30, 1990, was about 2,400 acre-ft and in the 1991 water year, was 2,200 acre-ft. Annual discharge of the spring, including municipal diversions, is an estimated 3,000 acre-ft/yr $\left(4 \mathrm{ft}^{3} / \mathrm{s}\right)$. 
Few flow measurements of Susie Creek have been made. Annual flows measured during water years 1956-58 at a gaging station about 15 mi upstream from its mouth ranged from 4,300 to 4,600 acre-ft/yr. Baseflows measured near the mouth of the stream as a part of the present study ranged from $0.36 \mathrm{ft}^{3} / \mathrm{s}$, in October 1991 , to $3.2 \mathrm{ft}^{3} / \mathrm{s}$, in November 1989. Values less than $1 \mathrm{ft}^{3} / \mathrm{s}$ probably reflect baseflow due only to long-term ground-water discharge into the stream channel.

Comparison of the flow of the Humboldt River at stream gaging stations above Carlin and below Carlin at Palisade for water years 1944-91 was useful for quantifying annual runoff and annual ground-water discharge from the combined three-basin area of Maggie, Marys, and Susie Creeks. The three basins of the study area constitute 95 percent of the area tributary to the river between the two stations. During the period of record, this reach of the river consistently gained flow. The total annual gain has ranged from a low of 5,000 acre-ft in 1961 to a high of 160,000 acre-ft in

1983. The average annual gain during the period was about 38,000 acre-ft/yr.

Comparison of average October flows at the Carlin and Palisade gaging stations indicates that baseflow gains in the river ranged from as little as $10 \mathrm{ft}^{3} / \mathrm{s}$ in some years to nearly $60 \mathrm{ft}^{3} / \mathrm{s}$ in 1985 , the year after the highest flows ever recorded. The low value of 10 $\mathrm{ft}^{3} / \mathrm{s}$ is thought to represent the minimum contribution of long-term ground-water discharge to the river channel from the three basins of the study area. Higher values represent a combination of long-term ground-water discharge and the short-term effects of low-altitude snowmelt.

Ground water moves from recharge areas in the Tuscarora and Independence Mountains into the basinfill aquifer in the upper Maggie Creek Basin. Most of this water leaves the basin as evapotranspiration and as inflow to the channel of Maggie Creek adjacent to the west side of the unnamed hills northeast of the Maggie Creek canyon. A small amount of ground water moves as underflow through permeable bedrock of Schroeder Mountain to the basin-fill aquifer in the lower Maggie Creek Basin. Ground water in the lower Maggie Creek Basin and adjacent parts of Marys and Susie Creek Basins moves southward and southeastward from recharge areas in the Independence Mountains, the unnamed hills, Schroeder Mountain, and Marys Mountain, and along lower Maggie Creek toward the Humboldt River, which is the destination (line sink) for ground-water flow in the area. A narrow trough in the potentiometric surface, extending southeastward from Schroeder Mountain and then southward from lower Maggie Creek, is the result of two separate phenomena. Near Schroeder Mountain, the trough is the result of pumping of production wells in basin-fill deposits and carbonate rocks. Between lower Maggie Creek and Carlin spring, the trough coincides with the subsurface extent of volcanic rocks that function as a permeable drain in which streamflow losses from lower Maggie Creek move rapidly southward and discharge at Carlin spring.

Chemical and isotopic compositions of ground water and surface water were used to evaluate ages of ground water, recharge sources, and hypothetical ground-water flow paths. Ground water in the study area generally is a calcium or sodium bicarbonate type, with the $\mathrm{pH}$ near neutral and dissolved-solids concentrations of less than $345 \mathrm{mg} / \mathrm{L}$. Tritium concentrations indicate that ground water from basin-fill deposits adjacent to the east and west sides of Schroeder Mountain and in carbonate rocks at the mountain is from 40 to more than 60 years old. In contrast, tritium concentrations indicate that water near recharge areas can be younger. For instance, water from Carlin spring and from two wells finished partly in volcanic rocks between the spring and Maggie Creek could be less than 20-30 years old.

Deuterium and oxygen-18 concentrations in ground water provide evidence for recharge sources in the study area. The isotopically lightest ground water found in the study area was from three flowing wells in the upper Maggie Creek Basin adjacent to the unnamed hills northeast of the Maggie Creek canyon. Ground water from these wells probably originated as highaltitude recharge in northern parts of the Tuscarora and Independence Mountains. Isotopically heavier ground water represents ground-water recharge at relatively lower altitudes in the southern parts of the two mountain ranges and at Marys Mountain.

Four hypothetical ground-water flow paths were evaluated using geochemical mass-transfer models. Model results suggest that each of the four groundwater flow paths is geochemically realistic. The first flow path extends from the recharge area in the southern Tuscarora Mountains to the area along upper Maggie Creek, where baseflow conditions and flowing wells indicate that ground water discharges to the stream channel. The second flow path extends from the same recharge area to Carlin spring, and represents ground-water flow from recharge areas in the southern 
Tuscarora Mountains and Marys Mountain. The third flow path extends from lower Maggie Creek to Carlin spring. The model results for the third flow path, and approximate ages of the water based on tritium concentrations, indicate that the movement of ground water through volcanic rocks is rapid and involves minimal mass transfer of constituents. The fourth flow path involves mixing water from the second and third flow paths. The model results suggest that water at Carlin spring consists of about 80 percent recharge from lower Maggie Creek and 20 percent recharge from Marys Mountain and the southern end of the Tuscarora Mountains.

The only source of water to the three basins of the study area is precipitation, and the only processes by which water leaves the area are streamflow and evapotranspiration. Total precipitation is an estimated $420,000 \mathrm{acre}-\mathrm{ft} / \mathrm{yr}$, and runoff-including groundwater discharge-is an estimated 38,000 acre-ft/yr. The remaining 380,000 acre-ft/yr is consumed as evapotranspiration at a rate of about $1 \mathrm{ft} / \mathrm{yr}$. The entire Maggie Creek Basin receives an estimated 270,000 acre-ft/yr of precipitation, Marys Creek Basin receives an estimated 30,000 acre-ft/yr as precipitation and 3,000 acre-ft/yr as underflow from the Maggie Creek Basin, and Susie Creek Basin receives 120,000 acre$\mathrm{ft} / \mathrm{yr}$ of precipitation. An estimated 270,000 acre-ft/yr leaves Maggie Creek Basin, 33,000 acre-ft/yr leaves Marys Creek Basin, and 120,000 acre-ft/yr leaves Susie Creek Basin.

Ground water is recharged from infiltration of precipitation mostly in mountainous areas, from infiltration of streamflow, and from underflow between basins of the study area. The Maggie Creek Basin receives an estimated 17,000 acre-ft/yr of recharge, Marys Creek Basin receives at least 4,000 acre-ft/yr, and Susie Creek Basin receives an estimated 6,000 acre-ft/yr. Ground water is discharged as evapotranspiration, inflow to stream channels, springflow, and underflow. Minimum ground-water discharge from the three basins is an estimated 12,000 acre-ft/yr for Maggie Creek, 4,000 acre-ft/yr for Marys Creek, and 2,000 acre-ft/yr for Susie Creek.

The combined three-basin area receives an estimated 25,000 acre-ft/yr of ground-water recharge, all as infiltration of precipitation. Ground-water discharge is an estimated 18,000 acre- $\mathrm{ft} / \mathrm{yr}$, and consists of about $11,000 \mathrm{acre}-\mathrm{ft} / \mathrm{yr}$ of evapotranspiration and 7,000 acre- $\mathrm{ft} / \mathrm{yr}$ of discharge to the Humboldt River channel. Ground-water underflow between the study area and adjacent basins is negligible.

For the ground-water budgets summarized above, recharge generally exceeds discharge, possibly because infiltration of precipitation through the soil zone is overestimated; instead, a larger proportion of precipitation may leave the area as runoff. In addition, groundwater discharge to the Humboldt River channel may be underestimated.

A conceptual model of the hydrologic system in the lower Maggie Creek area was developed as a part of the study. Hydrologic boundaries of the system consist of the following: (1) Bedrock of the Tuscarora and Independence Mountains, unnamed hills northeast of Maggie Creek canyon, Marys Mountain, and the Adobe Range form impermeable or poorly permeable lateral boundaries; (2) bedrock of Schroeder Mountain is sufficiently permeable that small amounts of ground water flow through the mountain between the upper and lower Maggie Creek Basins; (3) the Humboldt River is a line sink for ground-water flow and forms the southern boundary of the study area; (4) the water table represents the upper boundary of the shallow flow system over most of the area; and (5) the lower boundary for the shallow system, may be at the contact between basin-fill deposits and the underlying bedrock. Deep ground-water flow may be mostly in fractured bedrock beneath structural basins.

From March 1989 to September 1990, water levels in the study area declined as the result of pumping at Gold Quarry mine and a prolonged drought. The effects of the drought are most apparent along stream flood plains where water levels in shallow wells declined as much as $5 \mathrm{ft}$ at several wells and over $10 \mathrm{ft}$ at one. Water-level declines near Gold Quarry mine exceeded $5 \mathrm{ft}$ at most wells. The largest decline was $41 \mathrm{ft}$ at a well in carbonate rocks near a fault zone on the west side of Schroeder Mountain.

Water levels will decline in the carbonate and clastic sedimentary rocks at Schroeder Mountain as a result of the dewatering of Gold Quarry mine, which began in 1993. The extent of long-term water-level declines in basin-fill deposits beyond Schroeder Mountain will depend on the nature of the hydraulic connection between these deposits and the bedrock of the mountain. If the connection is poor, water levels may decline only in bedrock of Schroeder Mountain and immediately adjacent basin-fill deposits. If the hydraulic connection is better than presently thought, 
water-level declines may spread over a much larger area of basin-fill deposits east and west of Schroeder Mountain.

Mine dewatering also may affect the flow of Maggie Creek. Water-level declines in basin-fill deposits west of the Schroeder Mountain uplift would reduce flow of upper Maggie Creek, first by reducing baseflow, and later by increasing infiltration of streamflow to the underlying aquifer. The flow of lower Maggie Creek will be sustained during mine dewatering by releases of pumped ground water to the stream channel. However, Maggie Creek east of Schroeder Mountain may flow only during the snowmelt runoff once dewatering ceases. This reduction of flow eventually could affect the flow of Carlin spring, because streamflow losses from lower Maggie Creek are a recharge source for the spring.

The hydrologic effects of dewatering Gold Quarry mine might be reduced by impounding excess flows of Maggie Creek during the snowmelt runoff in a reservoir in Maggie Creek canyon. Such a reservoir could be a source of ground-water recharge where water levels have declined as a result of dewatering, and releases to the channel of Maggie Creek could be controlled so that flows do not exceed the capacity of the channel to transmit water to underlying aquifers. 
REFERENCES CITED

Bostic, R., Hitch, D., Van Gordon, L., and Swanson, R., 1991, Water resources data, Nevada, water year 1990: U.S. Geological Survey Water-Data Report NV-90-1, $358 \mathrm{p}$.

Bredehoeft, J.D., 1963, Hydrogeology of the lower Humboldt River basin, Nevada: Nevada Department of Conservation and Natural Resources, Water Resources Bulletin 21, $50 \mathrm{p}$.

Carmichael, R.S., 1989, Magnetic properties of rocks and minerals, in Carmichael, R.S., ed., Physical properties of rocks and minerals: Boca Raton, Fla., Chemical Rubber Co., p. 299-358.

Coats, R.R., 1987, Geology of Elko County, Nevada: Nevada Bureau of Mines and Geology Bulletin 101, $112 \mathrm{p}$.

Cooper, H.H., Jr., and Jacob, C.E., 1946, A generalized graphical method of evaluating formation constants and summarizing well-field history: Transactions of the American Geophysical Union, v. 27, no. 4, p. 526-534.

Craig, Harmon, 1961, Isotopic variations in meteoric waters: Science, v. 133, no. 3465, p. 1702-1703.

Drever, J.I., 1988, The geochemistry of natural waters: Englewood Cliffs, N. J., Prentice Hall, 437 p.

Eakin, T.E., 1961, Ground-water appraisal of Pine Valley, Eureka and Elko Counties, Nevada: Nevada Department of Conservation and Natural Resources, GroundWater Resources Reconnaissance Report 2,41 p.

Eakin, T.E., and Lamke, R.D., 1966, Hydrologic reconnaissance of the Humboldt River basin, Nevada: Nevada Department of Conservation and Natural Resources, Water Resources Bulletin 32, 107 p.

Eakin, T.E., Maxey, G.B., and Robinson, T.W., 1951, Ground water in Goshute and Antelope Valleys, Elko County, Nevada, in Eakin, T.E., Maxey, G.B., Robinson, T.W., Fredericks, J.C., and Loeltz, O.J., Contributions to the hydrology of eastern Nevada: Nevada State Engineer, Water Resources Bulletin 12, p. 17-34.

Ekburg, C.E., Rota, J.C., and Arkell, B.W., 1991, Geology and mineral deposits of the Maggie Creek subdistrict, Carlin trend, Eureka County, Nevada, in Raines, G.L., Lisle, R.E., Schager, R.W., and Wilkinson, W.H., Geology and ore deposits of the Great Basin: Geological Society of Nevada Symposium, April 1990, Proceedings, p. 625-633.

Ettner, D.C., 1989, Stratigraphy and structure of the Devonian autochthonous rocks, north-central Carlin trend of the southern Tuscarora Mountains, northern Eureka County, Nevada: Idaho State University, unpublished M.S. thesis, $177 \mathrm{p}$.
Evans, J.G., and Cress, L.D., 1972, Preliminary geologic map of the Schroeder Mountain quadrangle, Nevada: U.S. Geological Survey Miscellaneous Field Studies Map MF-324, scale 1:24,000.

Franke, O.L., Reilly, T.E., and Bennett, G.D., 1987, Definition of boundary and initial conditions in the analysis of saturated ground-water flow systems-An introduction: U.S. Geological Survey Techniques of Water-Resources Investigations, book 3, chap. B5, $15 \mathrm{p}$.

Frisbie, H.R., LaCamera, R.J., Riek, M.M., and Wood, D.B., 1983, Water resources data, Nevada, water year 1982: U.S. Geological Survey Water-Data Report NV-82-1, $360 \mathrm{p}$.

Garcia, K.T., Gortsema, G.C., Pennington, R.N., and Preissler, A.M., 1992, Water resources data, Nevada, water year 1991: U.S. Geological Survey Water-Data Report NV-91-1, 481 p.

Harrill, J.R., 1970, Determining transmissivity from the water-level recovery of a step-drawdown test, in Geological Survey Research 1970: U.S. Geological Survey Professional Paper 700-C, p. 212-213.

Harrington, H.D., 1954, Manual of the plants of Colorado: Chicago, The Swallow Press, 666 p.

Houghton, J.G., Sakamato, C.M., and Gifford, R.D., 1975, Nevada's weather and climate: Nevada Bureau of Mines and Geology Special Publication 2, 78 p.

Howe, J.W., 1950, Flow measurement, in Rouse, Hunter, ed., Engineering hydraulics: New York, John Wiley, p. 177-227.

Iman, R.L., and Conover, W.J., 1983, A modern approach to statistics: New York, John Wiley, 497 p.

Kaiser, Roy, 1991, Nevada annual data summary-Water year 1990: Reno, Nev., U.S. Soil Conservation Service, $22 \mathrm{p}$.

King, Clarence, 1878, Systematic geology-Geological exploration of the fortieth parallel, v. 1: Washington, D.C., U.S. Government Printing Office, 803 p.

Knutsen, G.C., and Wilson, M.L., 1990, Carlin trend, Nevada-Geological setting and subdistricts [abs.]: Geological Society of Nevada Great Basin Symposium, April 1990, Program with Abstracts, p. 66.

Lohman, S.W., 1972, Ground-water hydraulics: U.S. Geological Survey Professional Paper 708, 70 p.

Mabey, D.R., 1976, Aeromagnetic survey, in Smith, J.F., Jr., and Kettner, K.B., 1976, Stratigraphy of post-Paleozoic rocks and summary of resources in the Carlin-Pinon Range area, Nevada: U.S. Geological Survey Professional Paper 867-B, p. 43-44.

Maxey, G.B., and Jameson, C.H., 1948, Geology and water resources of Las Vegas, Pahrump, and Indian Spring Valleys, Clark and Nye Counties, Nevada: Nevada State Engineer, Water Resources Bulletin 5, $292 \mathrm{p}$. 
National Climatic Center, 1966-90, Climatological data, annual summaries, Nevada, 1966-90: Asheville, N.C., U.S. National Oceanic and Atmospheric Administration, v. 81 to v. 105 , no. 13 (published annually).

Nichols, W.D., 1993, Estimating discharge of shallow groundwater by transpiration from greasewood in the northern Great Basin: Water Resources Research, v. 29, no. 8, p. 2771-2778.

Olhoeft, G.R., and Johnson, G.R., 1989, Densities of rocks and minerals, in Carmichael, R.S., ed., Physical properties of rocks and minerals: Boca Raton, Fla., Chemical Rubber Co., p. 139-176.

Plummer, L.N., Prestemon, E.C., and Parkhurst, D.L., 1991, An interactive code for modelling net geochemical reactions along a flow path: U.S. Geological Survey Water-Resources Investigations Report 91-4078, 227 p.

Quiring, R.F., 1965, Annual precipitation amount as a function of elevation in Nevada south of 38 latitude: Las Vegas, Nev., U.S. Weather Bureau Research Station report, $8 \mathbf{p}$.

Regnier, Jerome, 1960, Cenozoic geology in the vicinity of Carlin, Nevada: Geological Society of America Bulletin, v. 71, p. 1189-1210.

Roberts, R.J., Montgomery, K.M., and Lehner, R.E., 1967, Geology and mineral resources of Eureka County, Nevada: Nevada Bureau of Mines Bulletin 64, 152 p.

Robertson, W.D., and Cherry, J.A., 1989, Tritium as an indicator of recharge and dispersion in a ground water system in central Ontario: Water Resources Research, v. 25 , no. 6, p. 1097-1109.

Robinson, T.W., 1958, Phreatophytes: U.S. Geological Survey Water-Supply Paper 1423, 84 p.

Rush, F.E., 1968, Index of hydrographic areas: Nevada Division of Water Resources, Information Report 6, $38 \mathrm{p}$.

Rush, F.E., and Everett, D.E., 1966, Water-resources appraisal of the Huntington Valley area, Elko and White Pine Counties, Nevada: Nevada Department of Conservation and Natural Resources, Water Resources Reconnaissance Report 35, $37 \mathrm{p}$.

Saltus, R.W., 1988, Gravity data for the state of Nevada on magnetic tape: Sioux Falls, S.D., EROS Data Center.

Sax, K.W., 1963, Northern Nevada reservoir site investigations: U.S. Geological Survey Open-File Report, 72 p.

Schroer, C.V., and Moosburner, Otto, 1978, Nevada streamflow characteristics: Nevada Division of Water Resources, Information Report 28, 478 p.

Scott, B.R., Smales, T.J., Rush, F.E., and Van Denburgh, A.S., 1971, Nevada's water resources: Nevada Division of Water Resources, Water for Nevada Report 3, 87 p.

Sharp, R.P., 1939, The Miocene Humboldt formation in northeastern Nevada: Journal of Geology, v. 47, no. 2, p. 133-160.
Smith, J.F., Jr., and Ketner, K.B., 1975, Stratigraphy of Paleozoic rocks in the Carlin-Pinon Range area, Nevada: U.S. Geological Survey Professional Paper 867-A, $87 \mathrm{p}$.

1976, Stratigraphy of post-Paleozoic rocks and summary of resources in the Carlin-Pinon Range area, Nevada: U.S. Geological Survey Professional Paper 867-B, $48 \mathrm{p}$.

Stewart, J.H., 1980, Geology of Nevada-A discussion to accompany the geologic map of Nevada: Nevada Bureau of Mines and Geology Special Publication 4, $136 \mathrm{p}$.

Stone, W.J., 1992, Ground-water recharge estimates, Maggie and Marys Creek basins, northeastern Nevada: Carlin, Nev., Newmont Gold Company, 34 p.

Stratigraphic Committee of the Eastern Nevada Geological Society, 1973, Correlation of Great Basin stratigraphic units: Nevada Bureau of Mines and Geology Bulletin $72,36 \mathrm{p}$.

U.S. Bureau of the Census, 1992, Idaho, Montana, Nevada, Wyoming computer file, in 1990 census of population and housing: U.S. Bureau of the Census Summary Tape File CD 90-3A-15 (1 computer laser optical disk, 4-3/4 in.).

U.S. Geological Survey, 1960, Compilation of records of surface waters of the United States, through September 1950-Part 10, The Great Basin: U.S. Geological Survey Water-Supply Paper 1314, 485 p.

-1963 , Compilation of records of surface waters of the United States, October 1950 to September 1960-Part 10, The Great Basin: U.S. Geological Survey WaterSupply Paper 1734, 318 p.

1990, National Water-Quality Laboratory services catalogue: U.S. Geological Survey Open-File Report 89-386, $131 \mathrm{p}$.

Webring, Michael, 1985, SAKI-A FORTRAN program for generalized linear inversion of gravity and magnetic profiles: U.S. Geological Survey Open-File Report $85-122,110 \mathrm{p}$.

Wershaw, R.L., Fishman, M.J., Grabbe, R.R., and Lowe, L.E., eds., 1987, Methods for determination of organic substances in water and fluvial sediment: U.S. Geological Survey Techniques of Water-Resources Investigations, book 5, chap. A3, 80 p.

William E. Nork, Inc., 1985, Carlin High School geothermal well: Reno, Nev., William E. Nork, Inc., report, 16 p.

Wood, W.W., 1976, Guidelines for collection and field analysis of ground-water samples for selected unstable constituents: U.S. Geological Survey Techniques of Water-Resources Investigations, book 1, chap. D2, $24 \mathrm{p}$. 


\section{BASIC DATA}

Tables in this section of the report list only some of the data collected during the study. Only those data specific to discussions in the text are included. All of the data collected during the study have been published elsewhere (Bostic and others, 1991, Garcia and others, 1992, and Pupacko and others, 1990). Table 11 lists streamflow and other information for surface-water sites. Table 12 lists information for springs. Table 13 lists water levels and other information for wells. Table 14 lists water-quality data for the two wells and two springs used to evaluate hypothetical ground-water flow paths. These data and other information for the sites can be retrieved from U.S. Geological Survey data bases upon request to the U.S. Geological Survey, Carson City, Nev. 
Table 11. Streamflow and other data for surface-water sites in lower Maggie Creek area, northeastern Nevada

[Type of station: $R$, continuously recording gaging station; $M$, site at which miscellaneous streamflow measurements are intermittently made. Availability of water-quality data: A, data in USGS data bases include analyses for major cations and anions, trace elements, nutrients, and, at some sites, analyses for oxygen-18 and deuterium; L, data in USGS data bases are limited to analyses for chloride, iodide, and bromide and/or oxygen-18 and deuterium; N, as far as is known, water at site has not been sampled. Symbol: --, not available or not applicable]

\begin{tabular}{|c|c|c|c|c|c|c|c|}
\hline \multicolumn{3}{|c|}{ Site identiflcation ${ }^{1}$} & \multirow{2}{*}{$\begin{array}{l}\text { Land- } \\
\text { surface } \\
\text { altitude } \\
\text { (feet } \\
\text { above aea } \\
\text { level) }\end{array}$} & \multirow[b]{2}{*}{$\begin{array}{l}\text { Type of } \\
\text { atation }\end{array}$} & \multicolumn{2}{|c|}{$\begin{array}{l}\text { Mlacellaneous fiow } \\
\text { meaaurements }\end{array}$} & \multirow{2}{*}{$\begin{array}{l}\text { Avall- } \\
\text { abllity } \\
\text { of water- } \\
\text { quality } \\
\text { data }\end{array}$} \\
\hline $\begin{array}{c}\text { Site } \\
\text { name } \\
\text { (figure 16) }\end{array}$ & $\begin{array}{l}\text { Downatream- } \\
\text { order } \\
\text { number }\end{array}$ & Land-net location & & & Date (time) & $\begin{array}{c}\text { Dlscharge } \\
\text { (cubic feet } \\
\text { per } \\
\text { aecond, } \\
\text { rounded) }\end{array}$ & \\
\hline \multicolumn{8}{|c|}{ Humboldt River } \\
\hline HR-1 & 10321000 & SESE S21 T33N R53E & 4,932 & $\mathbf{R}$ & -- & -- & A \\
\hline HR-2 & 10321100 & SESW S20 T33N R53E & 4,940 & $\mathbf{M}$ & $10-22-91(0930)$ & 23 & $\mathbf{N}$ \\
\hline HR-3 & 10321250 & SESW S20 T33N R53E & 4,920 & $\mathbf{M}$ & $\begin{array}{r}11-21-88(1010) \\
11-13-89(1100) \\
7-26-91(1041) \\
7-26-91(1655)\end{array}$ & $\begin{array}{l}45 \\
44 \\
61 \\
50\end{array}$ & L \\
\hline HR-4 & 10321600 & NWSW S25 T33N R52E & 4,900 & $\mathbf{M}$ & $\begin{array}{l}11-21-88(1150) \\
11-13-89(1400)\end{array}$ & $\begin{array}{l}47 \\
49\end{array}$ & $\mathrm{~N}$ \\
\hline HR-5 & 10322100 & SWSE S26 T33N R52E & 4,890 & $\mathbf{M}$ & $\begin{array}{l}11-21-88(1250) \\
11-13-89(1500)\end{array}$ & $\begin{array}{l}46 \\
49\end{array}$ & $\mathbf{N}$ \\
\hline HR-6 & 10322110 & NENE S34 T33N R52E & 4,880 & $\mathbf{M}$ & $\begin{array}{l}11-21-88(1345) \\
11-13-89(1550) \\
11-14-89(1030)\end{array}$ & $\begin{array}{l}50 \\
53 \\
50\end{array}$ & $\mathbf{N}$ \\
\hline HR-7 & 10322200 & NESE S33 T33N R52E & 4,880 & $\mathbf{M}$ & $\begin{array}{r}11-21-88(1435) \\
11-14-89(1140) \\
7-26-91(1220) \\
10-22-91(1100)\end{array}$ & $\begin{array}{l}46 \\
51 \\
69 \\
27\end{array}$ & N \\
\hline HR-8 & 10322400 & SWNESW S04 T32N R52E & 4,870 & $\mathbf{M}$ & $\begin{array}{r}11-21-88(1550) \\
11-14-89(1255) \\
7-26-91(1340)\end{array}$ & $\begin{array}{l}62 \\
54 \\
69\end{array}$ & L \\
\hline HR-9 & 10322425 & SWNW S20 T32N R52E & 4,860 & $\mathbf{M}$ & $10-22-91(0950)$ & 32 & $\mathrm{~N}$ \\
\hline HR-10 & 10322500 & SESE S35 T32N R51E & 4,826 & $\mathbf{R}$ & $\begin{array}{r}7-26-91(1055) \\
7-26-91(1450) \\
10-22-91(1055)\end{array}$ & $\begin{array}{l}79 \\
63 \\
32\end{array}$ & $\mathrm{~L}$ \\
\hline \multicolumn{8}{|c|}{ Maggie Creek } \\
\hline MC-1 & 10321940 & SENE S22 T34N R51E & 5,130 & $\mathbf{M}$ & $\begin{array}{c}8-29-88(1210) \\
9-23-88(1050) \\
10-26-88(1025) \\
11-21-88(--) \\
4-13-89(0930) \\
4-13-89(1235) \\
6-23-89(0940) \\
6-23-89(1330) \\
11-14-89(1030) \\
8-22-90(--) \\
6-18-91(--) \\
6-19-91(--) \\
10-24-91(1245)\end{array}$ & $\begin{array}{c}1.6 \\
3.1 \\
4.4 \\
5.2 \\
200 \\
190 \\
13 \\
13 \\
8.8 \\
4.2 \\
7.2 \\
6.7 \\
5.8\end{array}$ & L \\
\hline
\end{tabular}


Table 11. Streamflow and other data for surface-water sites in lower Maggie Creek area, northeastern Nevada-Continued

\begin{tabular}{|c|c|c|c|c|c|c|c|}
\hline \multicolumn{3}{|c|}{ Site identification ${ }^{1}$} & \multirow{2}{*}{$\begin{array}{c}\text { Land- } \\
\text { surface } \\
\text { aititude } \\
\text { (feet } \\
\text { above sea } \\
\text { ievei) }\end{array}$} & \multirow[b]{2}{*}{$\begin{array}{l}\text { Type of } \\
\text { station }\end{array}$} & \multicolumn{2}{|c|}{ Misceilaneous flow measurements } & \multirow{2}{*}{$\begin{array}{c}\text { Avall- } \\
\text { abillty } \\
\text { of water- } \\
\text { quailty } \\
\text { data }\end{array}$} \\
\hline $\begin{array}{c}\text { Site } \\
\text { name } \\
\text { (figure 16) }\end{array}$ & $\begin{array}{c}\text { Downstream- } \\
\text { order } \\
\text { number }\end{array}$ & Land-net location & & & Date (t|me) & $\begin{array}{l}\text { Discharge } \\
\text { (cubic feet } \\
\text { per second, } \\
\text { rounded) }\end{array}$ & \\
\hline \multicolumn{8}{|c|}{ Maggie Creek-Continned } \\
\hline MC-2 & 10321945 & SWNE S26 T34N R51E & 5,100 & $\mathbf{M}$ & $\begin{array}{c}8-29-88(1305) \\
9-23-88(1200) \\
10-26-88(1120) \\
11-21-88(--) \\
4-13-89(1025) \\
6-23-89(1040) \\
11-14-89(1145) \\
8-22-90(1115) \\
6-19-91(--) \\
10-24-91(1345)\end{array}$ & $\begin{array}{c}0.68 \\
2.8 \\
4.0 \\
10 \\
200 \\
13 \\
8.8 \\
3.6 \\
5.6 \\
4.2\end{array}$ & $L$ \\
\hline MC-3 & 10321950 & SENESE S26 T34N R51E & 5,100 & $\mathbf{R}$ & $\begin{array}{c}8-29-88(1335) \\
9-23-88(1600) \\
10-26-88(--) \\
11-21-88(--) \\
4-13-89(1100) \\
6-23-89(1130) \\
9-22-89(--) \\
11-14-89(1230) \\
8-22-90(--) \\
6-19-91(1015) \\
10-24-91(1400)\end{array}$ & $\begin{array}{c}.15 \\
1.6 \\
3.3 \\
10 \\
180 \\
12 \\
5.0 \\
8.2 \\
3.4 \\
5.4 \\
2.1\end{array}$ & A \\
\hline MC-4 & 10321955 & SWNWS32 T34N R52E & 5,030 & $\mathbf{M}$ & $\begin{array}{c}8-29-88(--) \\
9-23-88(--) \\
10-26-88(--) \\
11-21-88(--) \\
4-13-89(1148) \\
4-14-89(0955) \\
4-14-89(1415) \\
6-23-89(0945) \\
6-23-89(1225) \\
11-14-89(1400) \\
8-22-90(1240) \\
6-19-91(--) \\
10-24-91(--)\end{array}$ & $\begin{array}{c}0 \\
0 \\
1.8 \\
6.6 \\
190 \\
190 \\
190 \\
9.7 \\
11 \\
6.8 \\
1.8 \\
4.3 \\
0\end{array}$ & $\mathbf{N}$ \\
\hline MC-5 & 10321965 & SWSW S04 T33N R52E & 4,990 & $\mathbf{M}$ & $\begin{array}{c}8-29-88(--) \\
9-23-88(--) \\
10-26-88(--) \\
11-21-88(--) \\
4-14-89(1050) \\
6-23-89(1035) \\
11-14-89(1500) \\
8-22-90(--) \\
6-19-91(--) \\
10-24-91(--)\end{array}$ & $\begin{array}{c}0 \\
0 \\
0 \\
5.6 \\
180 \\
8.2 \\
5.2 \\
0 \\
1.6 \\
0\end{array}$ & $\mathbf{N}$ \\
\hline
\end{tabular}


Table 11. Streamflow and other data for surface-water sites in lower Maggie Creek area, northeastern Nevada—Continued

\begin{tabular}{|c|c|c|c|c|c|c|c|}
\hline \multicolumn{3}{|c|}{ Site Identification ${ }^{1}$} & \multirow{2}{*}{$\begin{array}{l}\text { Land- } \\
\text { surface } \\
\text { altitude } \\
\text { (feet } \\
\text { above sea } \\
\text { level) }\end{array}$} & \multirow[b]{2}{*}{$\begin{array}{l}\text { Type of } \\
\text { station }\end{array}$} & \multicolumn{2}{|c|}{ Misceilaneous flow measurements } & \multirow{2}{*}{$\begin{array}{l}\text { Avall- } \\
\text { ablilty } \\
\text { of water- } \\
\text { quality } \\
\text { data }\end{array}$} \\
\hline $\begin{array}{c}\text { Site } \\
\text { name } \\
\text { (figure 16) }\end{array}$ & $\begin{array}{c}\text { Downstream- } \\
\text { order } \\
\text { number }\end{array}$ & Land-net iocation & & & Date (time) & $\begin{array}{l}\text { Discharge } \\
\text { (cublc feet } \\
\text { per second, } \\
\text { rounded) }\end{array}$ & \\
\hline \multicolumn{8}{|c|}{ Maggie Creek-Continued } \\
\hline MC-6 & 10321970 & NENWSE S09 T33N R52E & 4,980 & $\mathbf{R}$ & $\begin{array}{c}8-29-88(--) \\
9-23-88(--) \\
10-26-88(--) \\
11-21-88(--) \\
4-14-89(1140) \\
6-23-89(1140) \\
11-14-89(1615) \\
8-22-90(--) \\
6-19-91(1055) \\
10-24-91(--)\end{array}$ & $\begin{array}{c}0 \\
0 \\
0 \\
0 \\
180 \\
6.1 \\
4.0 \\
0 \\
.94 \\
0^{.94}\end{array}$ & $\mathbf{L}$ \\
\hline MC-7 & 10321975 & NENE S22 T33N R52E & 4,930 & $\mathbf{M}$ & $\begin{array}{c}8-29-88(--) \\
9-23-88(--) \\
10-26-88(--) \\
11-21-88(--) \\
4-14-89(1240) \\
6-23-91(1220) \\
11-14-89(--) \\
8-22-90(--) \\
6-19-91(--) \\
10-24-91(--)\end{array}$ & $\begin{array}{c}0 \\
0 \\
0 \\
0 \\
170 \\
.92 \\
0 \\
0 \\
0 \\
0\end{array}$ & $\mathbf{N}$ \\
\hline MC-8 & 10322000 & NESENW S26 T33N R52E & 4,910 & $\mathbf{M}$ & $\begin{array}{c}8-29-88(--) \\
9-23-88(--) \\
10-26-88(--) \\
11-21-88(--) \\
4-14-89(1330) \\
6-23-89(1255) \\
9-22-89(--) \\
11-13-89(1250) \\
8-22-90(--) \\
6-19-91(--) \\
10-24-91(--)\end{array}$ & $\begin{array}{c}0 \\
0 \\
0 \\
0 \\
170 \\
.50 \\
0 \\
1.4 \\
0 \\
.14 \\
0\end{array}$ & $\mathrm{~L}$ \\
\hline \multicolumn{8}{|c|}{ Marys Creek } \\
\hline MA-1 & 10322150 & SESESE S28 T33N R52E & 4,920 & $\mathbf{R}$ & $\begin{array}{r}11-21-88(1420) \\
5-12-89(1030) \\
11-13-89(1645) \\
11-17-89(1100)\end{array}$ & $\begin{array}{l}4.1 \\
3.4 \\
3.8 \\
3.0\end{array}$ & A \\
\hline \multicolumn{8}{|c|}{ Susie Creek } \\
\hline SU-1 & 10321590 & NWNENW S25 T33N R52E & 4,910 & $\mathbf{M}$ & $\begin{array}{l}11-21-88(1040) \\
11-13-89(1200) \\
10-24-91(1445)\end{array}$ & $\begin{array}{l}0.98 \\
3.2 \\
.36\end{array}$ & $\mathrm{~L}$ \\
\hline
\end{tabular}

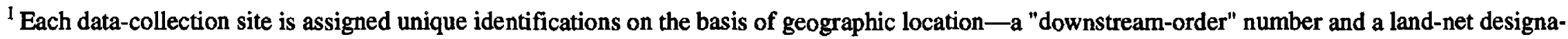
tion. In this report, a short site name also is used (for example, HR-1).

In the downstream-order system, an eight-digit number is used to identify each site. For example, site number 10321000 (site HR-1) consists of a twodigit part number (10) followed by a six-digit downstream-order number (321000). The part number refers to a drainage area or group of areas that is generally regional in extent. Records in this report are for sites in Part 10 (the Great Basin). The downstream-order number is assigned according to the geographic location of the station in the drainage network; larger number stations are downstream from smaller number stations.

The land-net designation is based on the official rectangular subdivision of the public lands, referenced to the Mount Diablo base line and meridian. Each designation consists of four units. For example, the designation for site HR-1 is SESE S21 T33N R53E. This site is in the southeast quarter of the southeast quarter of section 21, Township 33 north, Range 53 east, Mount Diablo base line and meridian.
} 
Table 12. Data for springs in lower Maggie Creek area, northeastern Nevada

[Water use: P, public supply; S, stock; U, unused. Availability of water-quality data: A, data in USGS data base include analyses for major cations and anions, trace metals, nutrients, tritium, oxygen-18, and deuterium; L, data in USGS data base limited to analyses for chloride, iodide, bromide, oxygen-18, and deuterium]

\begin{tabular}{|c|c|c|c|c|c|c|}
\hline \multicolumn{3}{|c|}{ Site designatlons 1} & \multirow[b]{2}{*}{ Name $^{2}$} & \multirow{2}{*}{$\begin{array}{l}\text { Land- } \\
\text { surface } \\
\text { altitude } \\
\text { (feet } \\
\text { above sea } \\
\text { levei) }\end{array}$} & \multirow[b]{2}{*}{$\begin{array}{c}\text { Water } \\
\text { use }\end{array}$} & \multirow{2}{*}{$\begin{array}{c}\text { Avall- } \\
\text { ability } \\
\text { of } \\
\text { water- } \\
\text { quality } \\
\text { data }\end{array}$} \\
\hline $\begin{array}{c}\text { Site } \\
\text { number } \\
\text { (figure 24) }\end{array}$ & $\begin{array}{l}\text { Local } \\
\text { Identiflcation }\end{array}$ & $\begin{array}{l}\text { Standard } \\
\text { identification }\end{array}$ & & & & \\
\hline 101 & 51 N35 E50 13BBACl & 405456116183201 & Unnamed & 6,120 & $S$ & A \\
\hline 102 & 51 N35 E51 30DDCB1 & 405314116164601 & Unnamed & 5,560 & $\mathrm{~S}$ & A \\
\hline 103 & 52 N32 E52 05CDBA1 & 404104116091401 & Unnamed & 5,000 & $S$ & A \\
\hline 104 & 52 N33 E51 15BCC 1 & 404449116141301 & Unnamed & 5,880 & $S$ & L \\
\hline 105 & 52 N33 E51 21DCAA1 & 404342116143801 & Cherry Spring & 6,040 & $\mathbf{S}$ & L \\
\hline 106 & 52 N33 E52 28DC 1 & 404242116074001 & Carlin spring & 4,940 & $P$ & A \\
\hline 107 & 52 N33 E52 33DBDCl & 404200116074801 & Unnamed & 4,890 & $\mathrm{U}$ & $\mathrm{L}$ \\
\hline
\end{tabular}

${ }^{1}$ In this table, each site is identified by U.S. Geological Survey site designations that consist of the local (Nevada) siteidentification system and a standard identification number. The two designations are usually the most convenient means of identifying and retrieving information for a specific site from computer data bases operated by the U.S. Geological Survey. For convenience, a short site number also is used in this report. For springs, the numbers range from 101 to 107.

The local site-identification system is based on an index of hydrographic areas in Nevada (Rush, 1968) and on the rectangular subdivision of the public lands referenced to the Mount Diablo base line and meridian. Each number consists of four units: The first unit is the hydrographic area number. The second unit is the township, preceded by an $\mathbf{N}$ to indicate location north of the base line. The third unit is the range, preceded by an $E$ to indicate location east of the meridian. The fourth unit consists of the section number and letters designating the quarter section, quarter-quarter section, and so on (A, B, C, and D indicate the northeast, northwest, southwest, and southeast quarters, respectively), followed by a number indicating the sequence in which the well was recorded. For example, the local identification for site number 101 in this table is 51 N35 E50 13BBAC1. This site is in the Maggie Creek Basin (hydrographic area 51) and is the first site recorded in the southwest quarter (C) of the northeast quarter (A) of the northwest quarter (B) of the northwest quarter (B) of section 13, Township 35 north, Range 50 east, Mount Diablo base line and meridian.

The standard identification for each site is based on the grid system of latitude and longitude. The number consists of 15 digits. The first six digits denote degrees, minutes, and seconds of latitude; the next seven digits denote degrees, minutes, and seconds of longitude; and the last two digits (assigned sequentially) identify sites within a 1-second grid. For example, the standard identification for site number 101 in this table is 405456116183201 . This number refers to $40^{\circ} 54^{\prime} 56^{\prime \prime}$ latitude and $116^{\circ} 18^{\prime} 32^{\prime \prime}$ longitude, and it is the first site recorded in that 1 -second grid. This 15-digit number is retained as a permanent identifier even if a more precise latitude and longitude are determined later.

${ }^{2}$ Except for Cherry Spring, springs are not formally named. However, the informal name, Carlin spring, is used for the large spring that is the water supply for Carlin. 


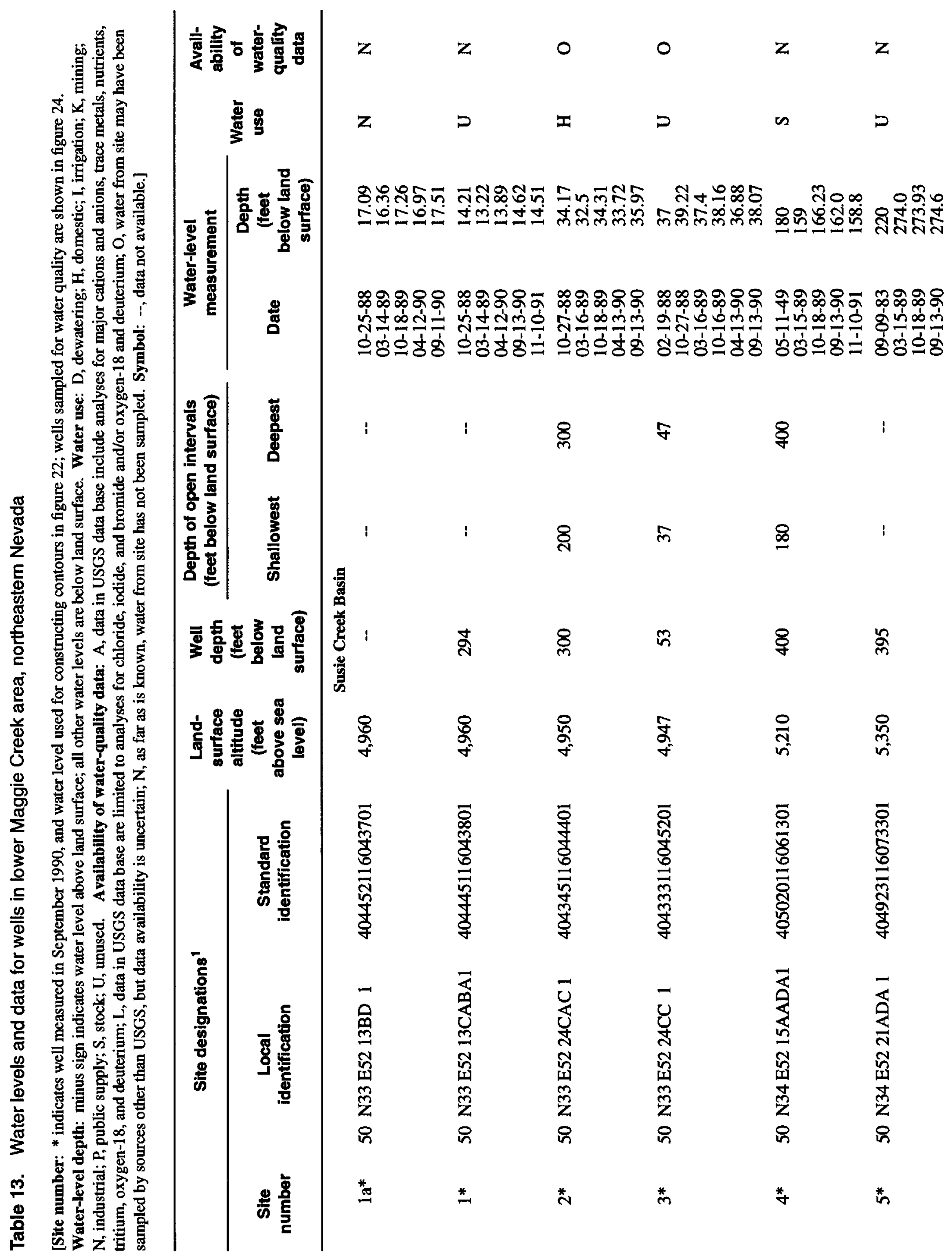




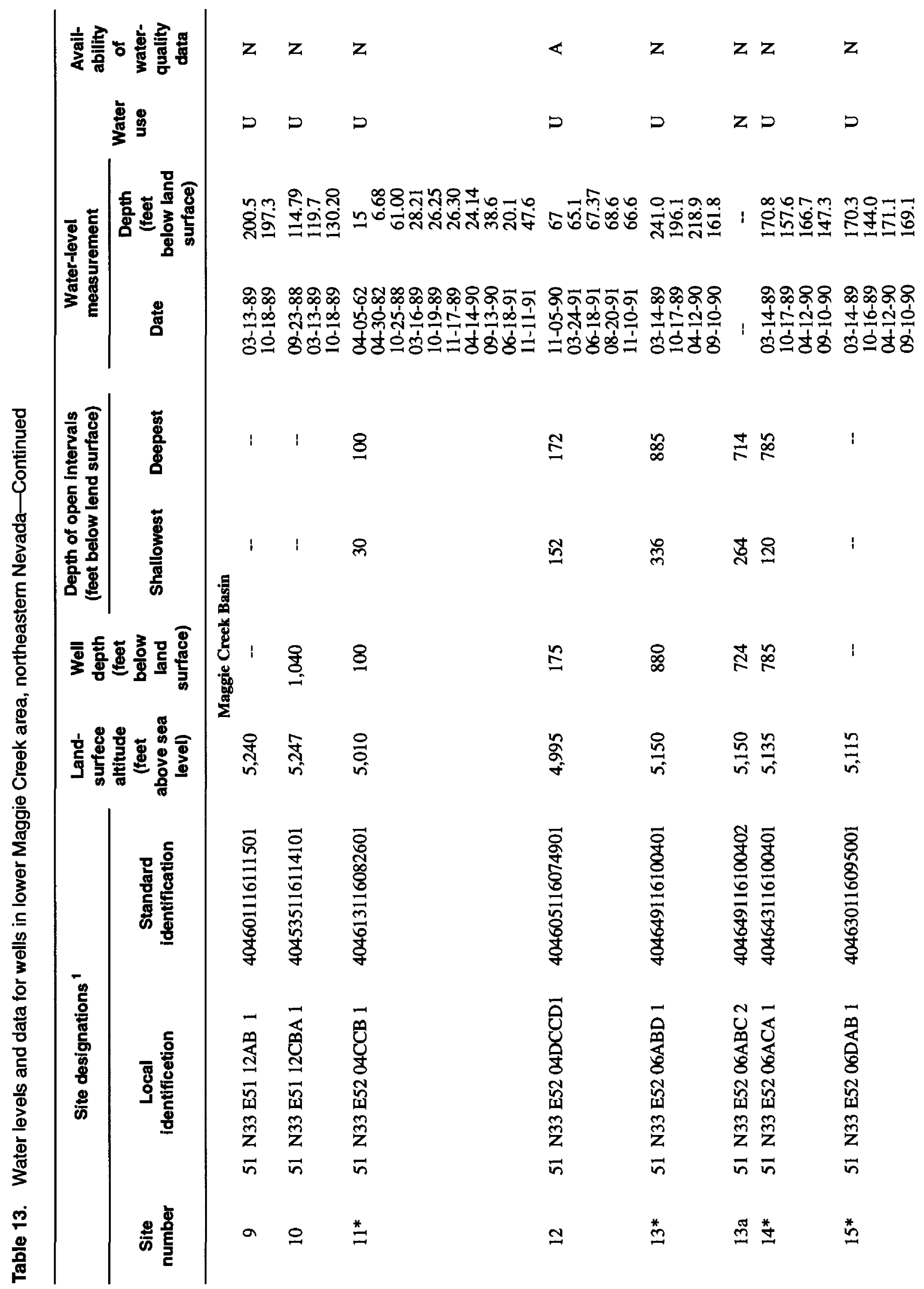




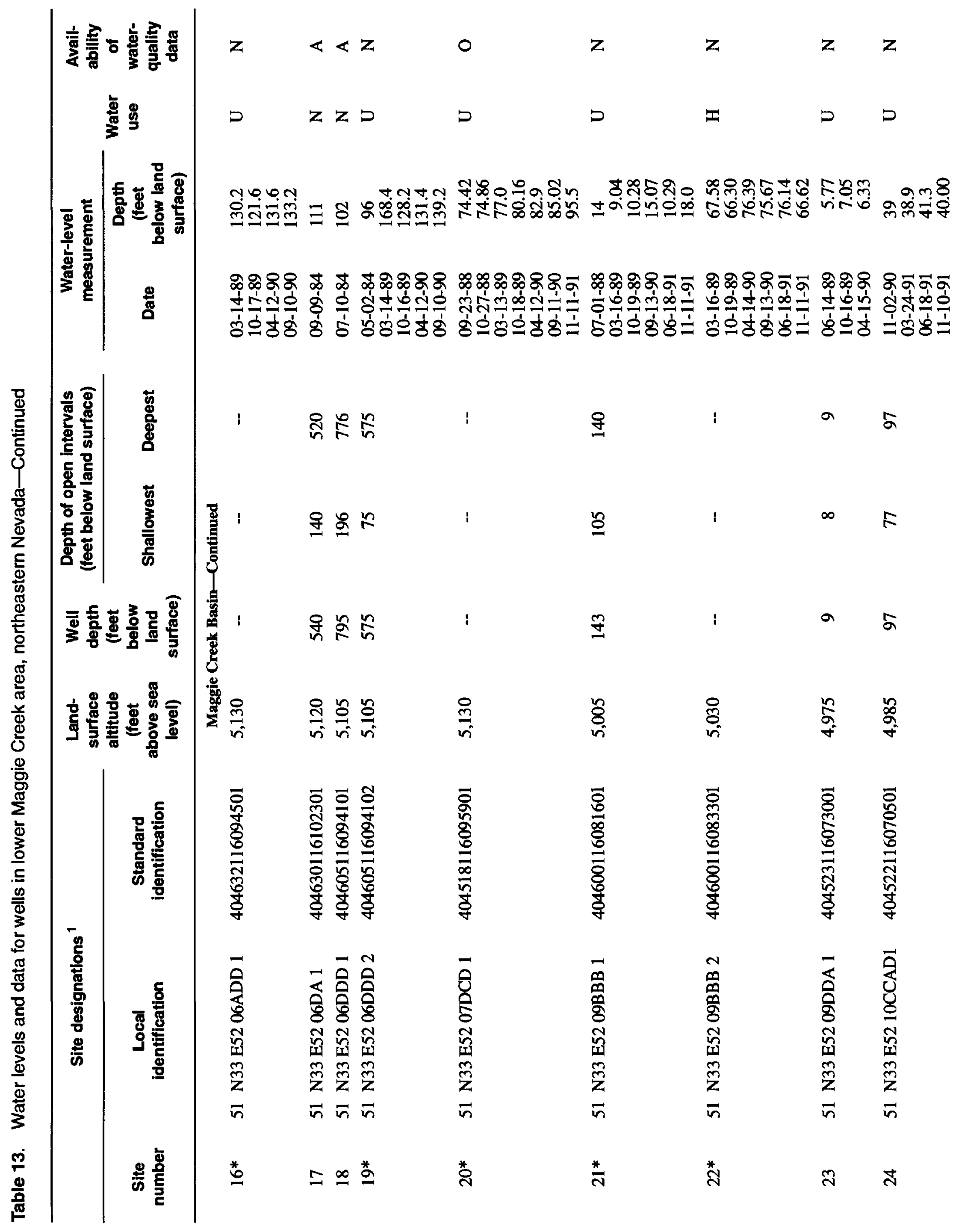




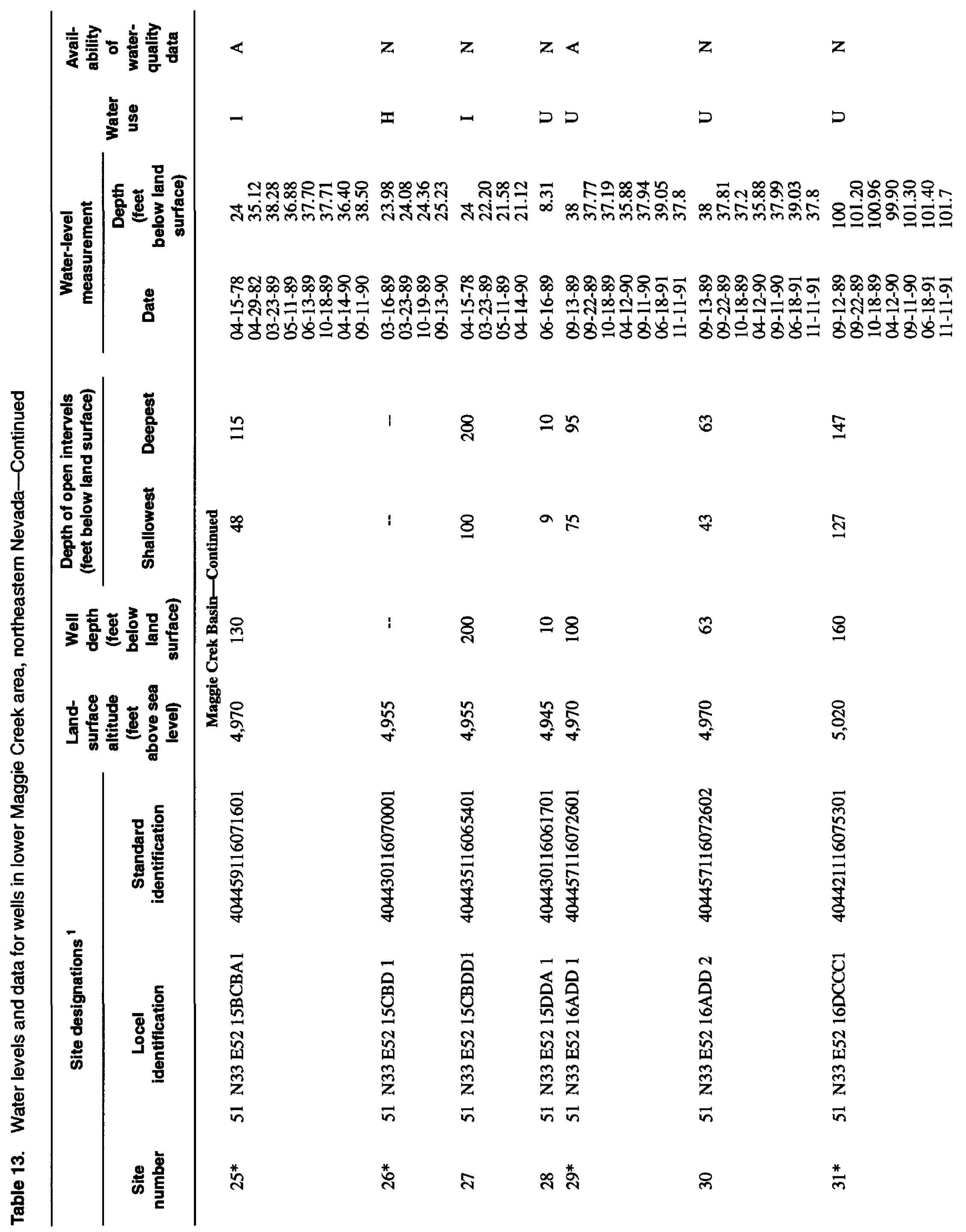




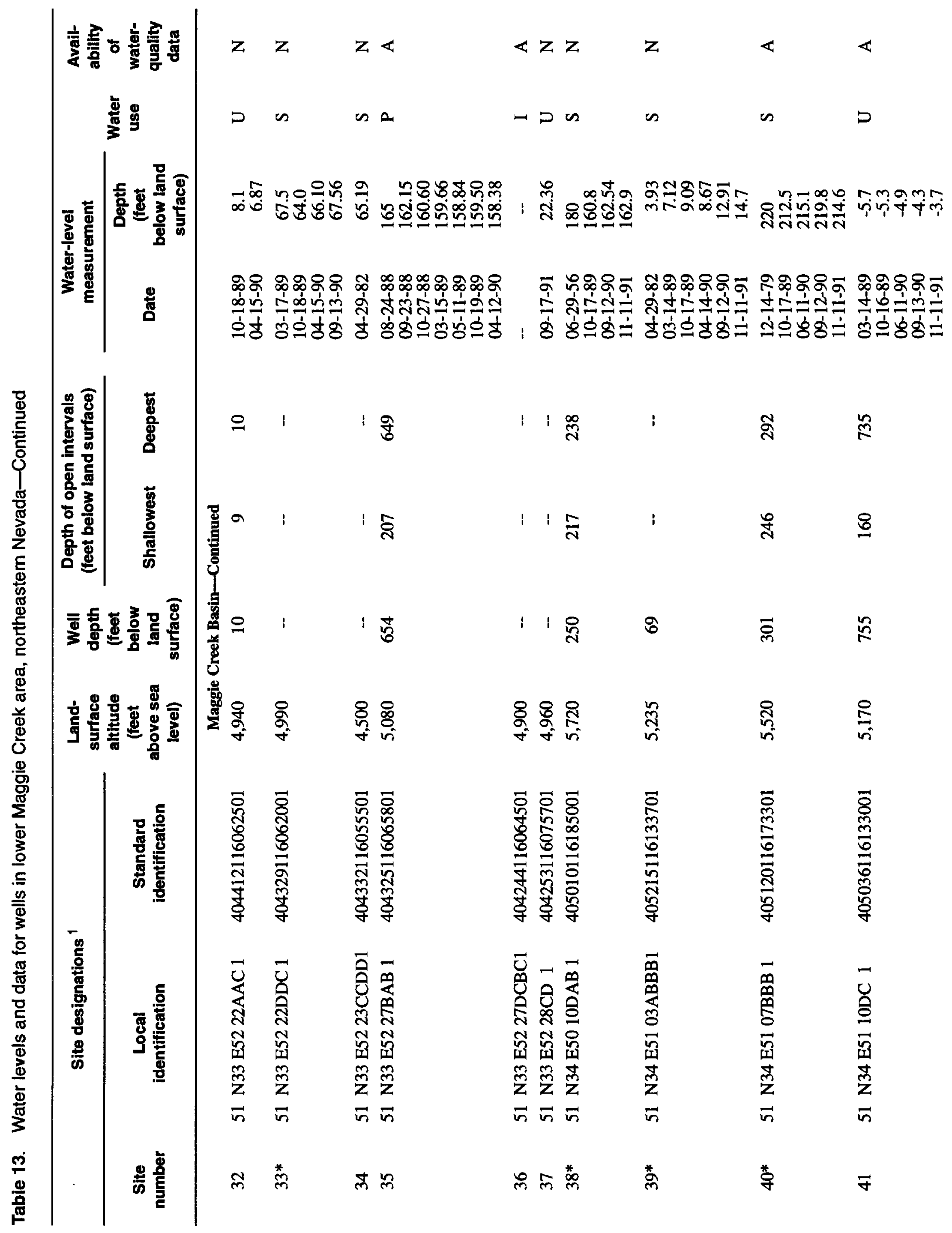




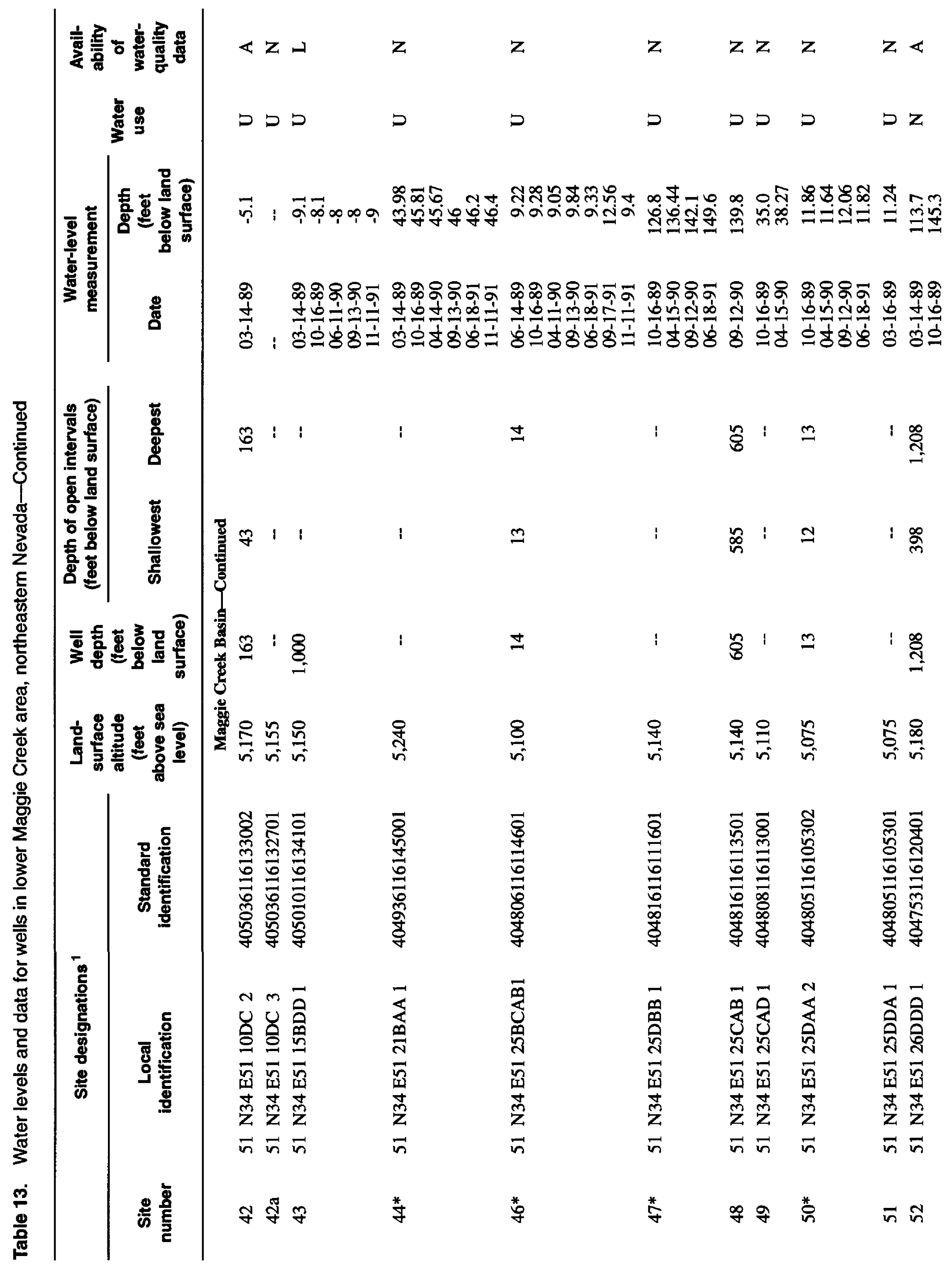




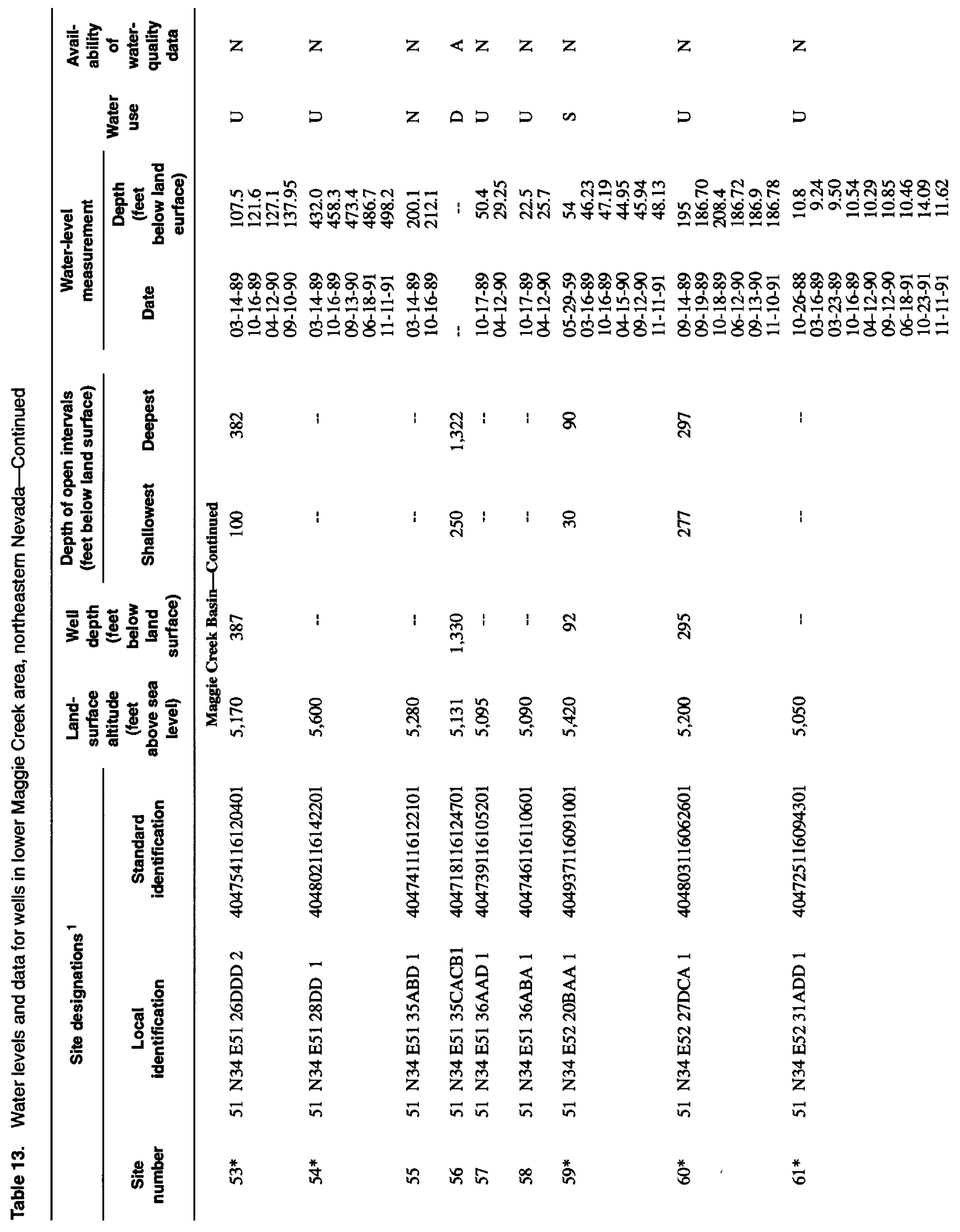




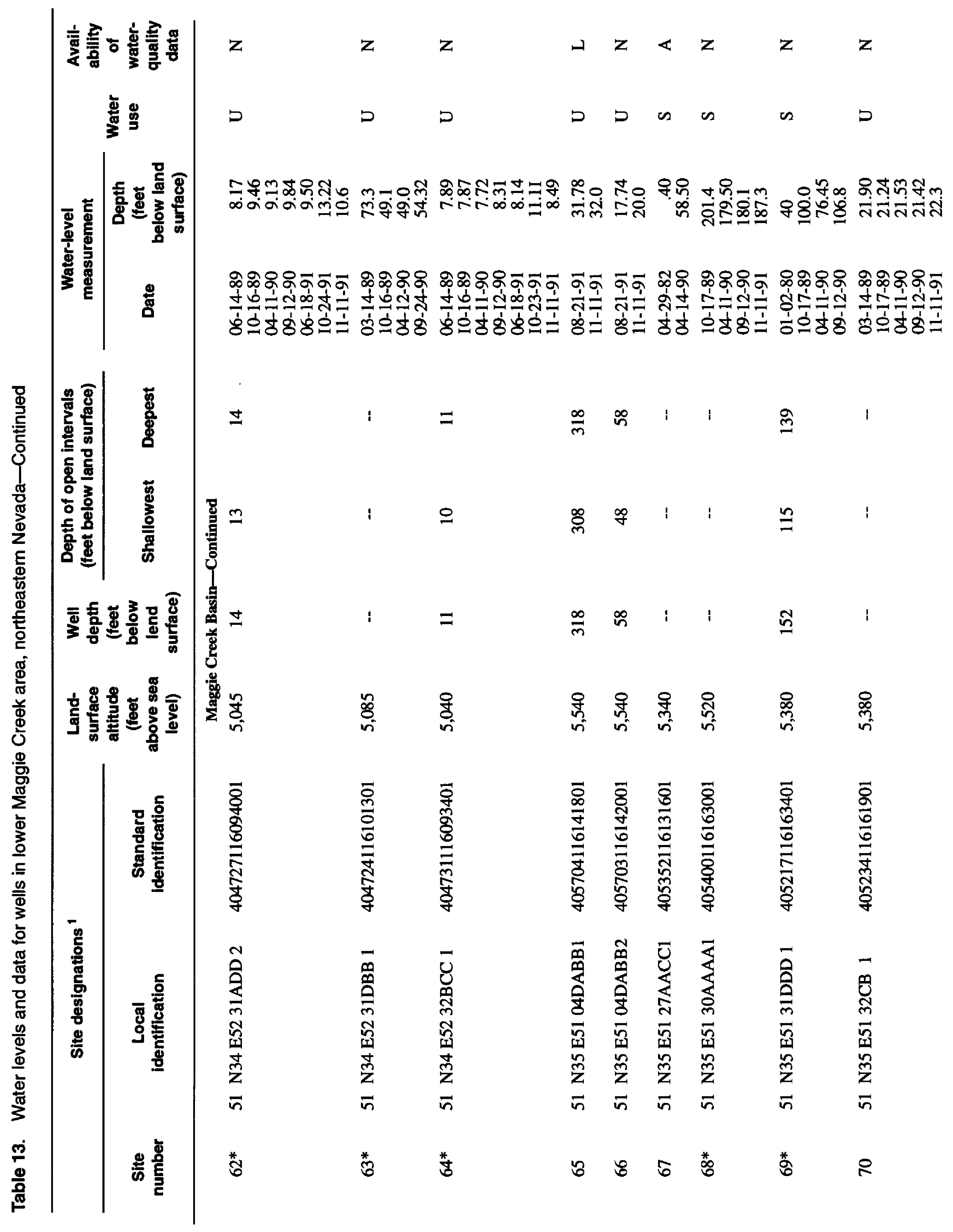




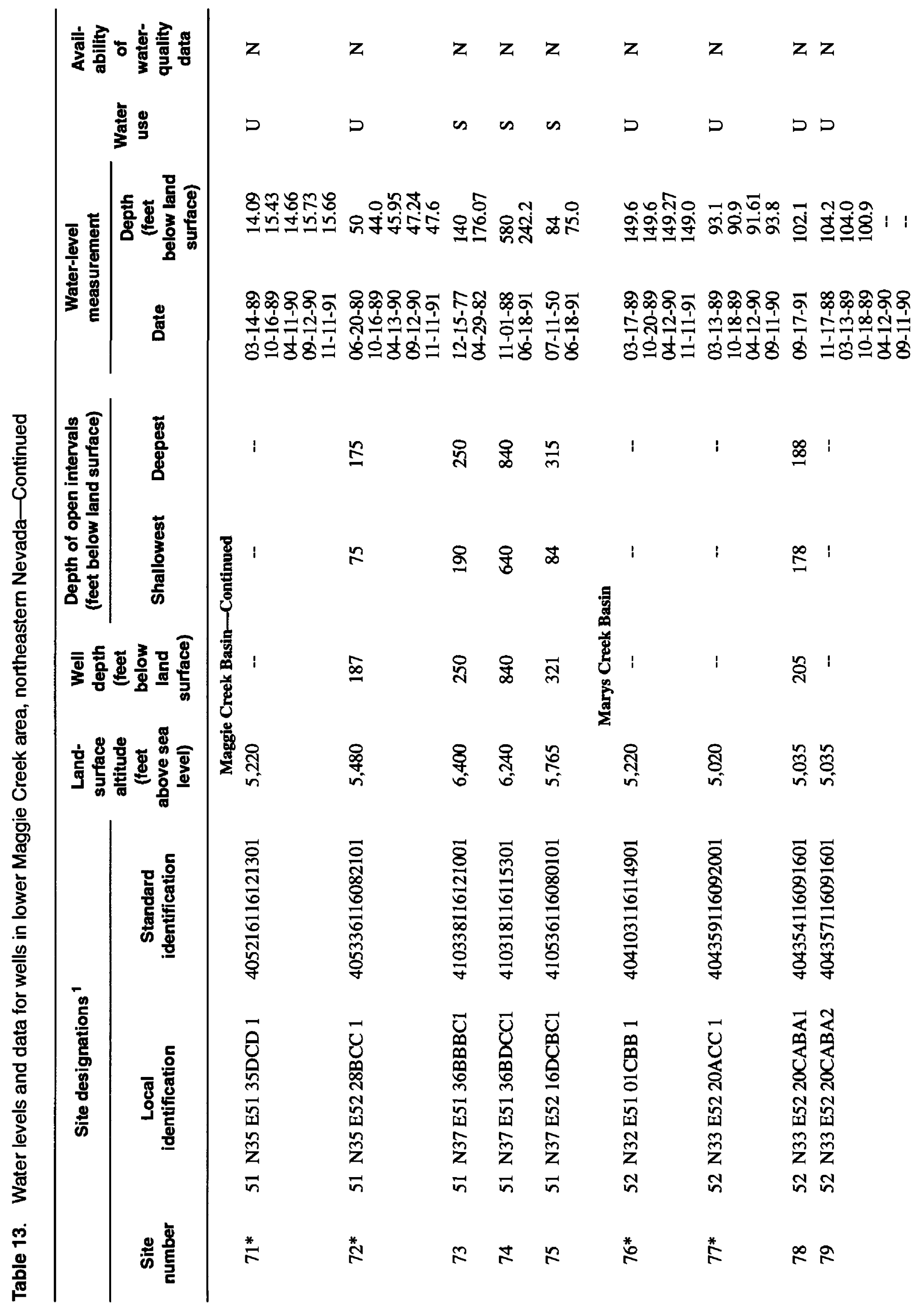




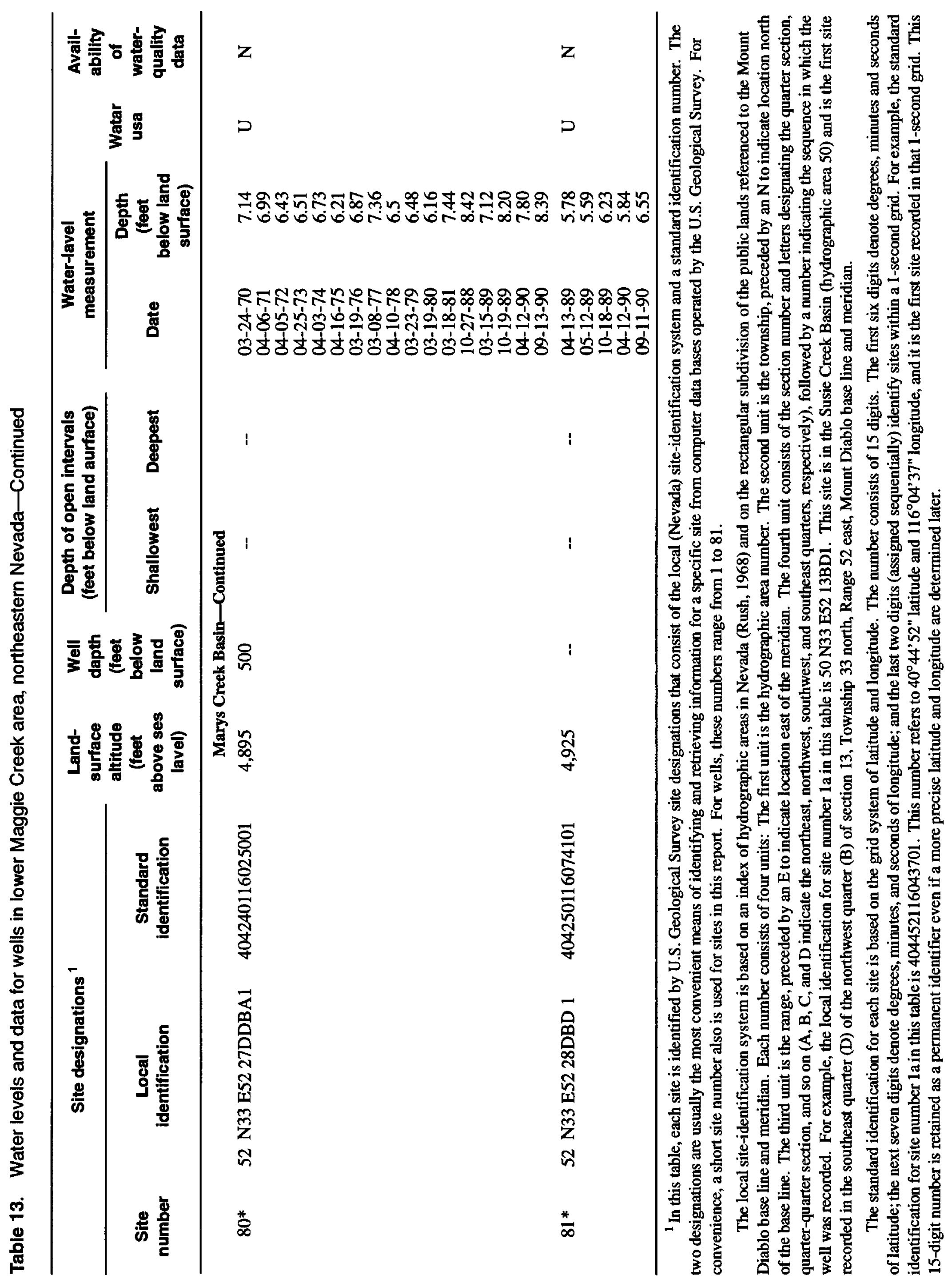




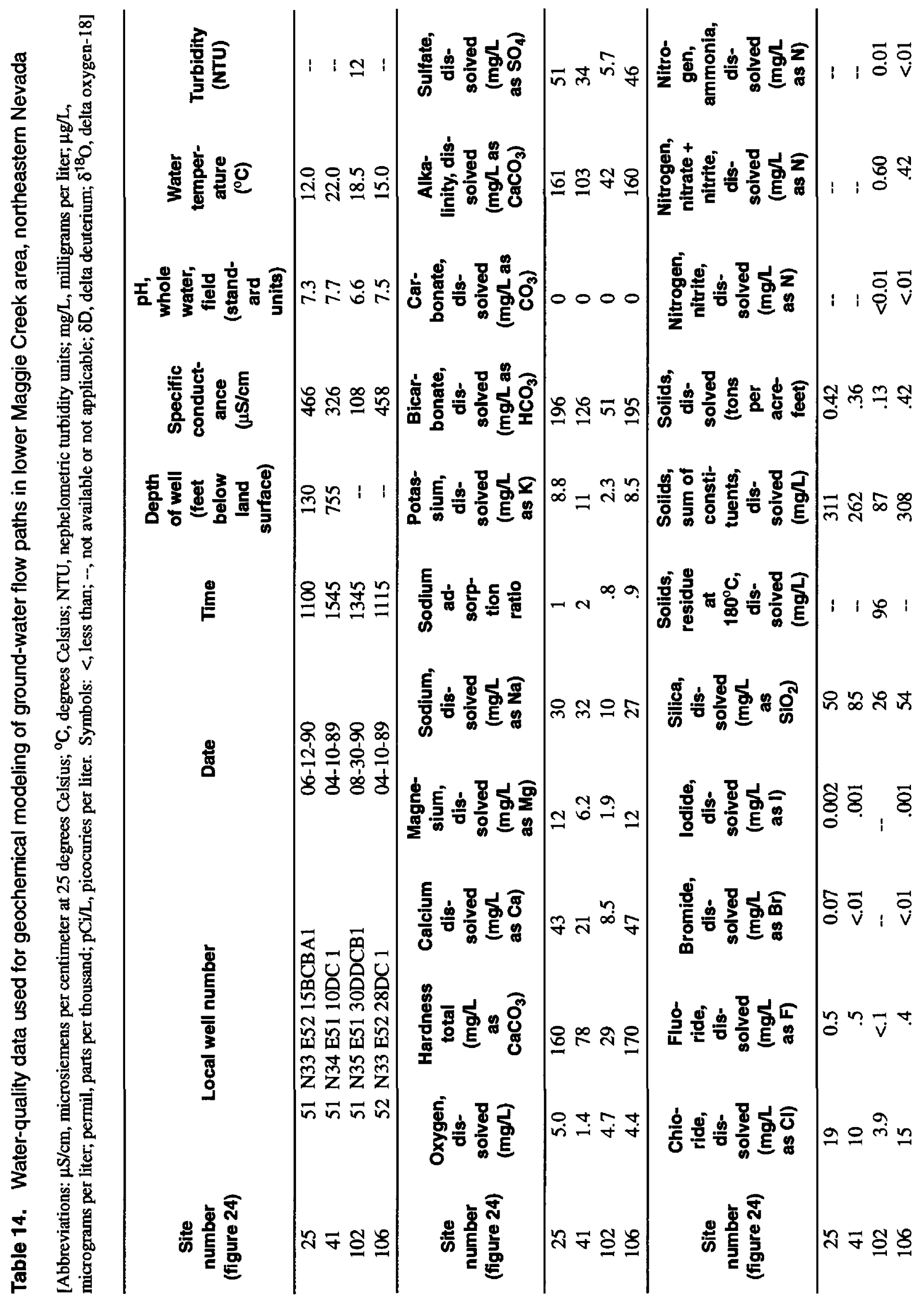




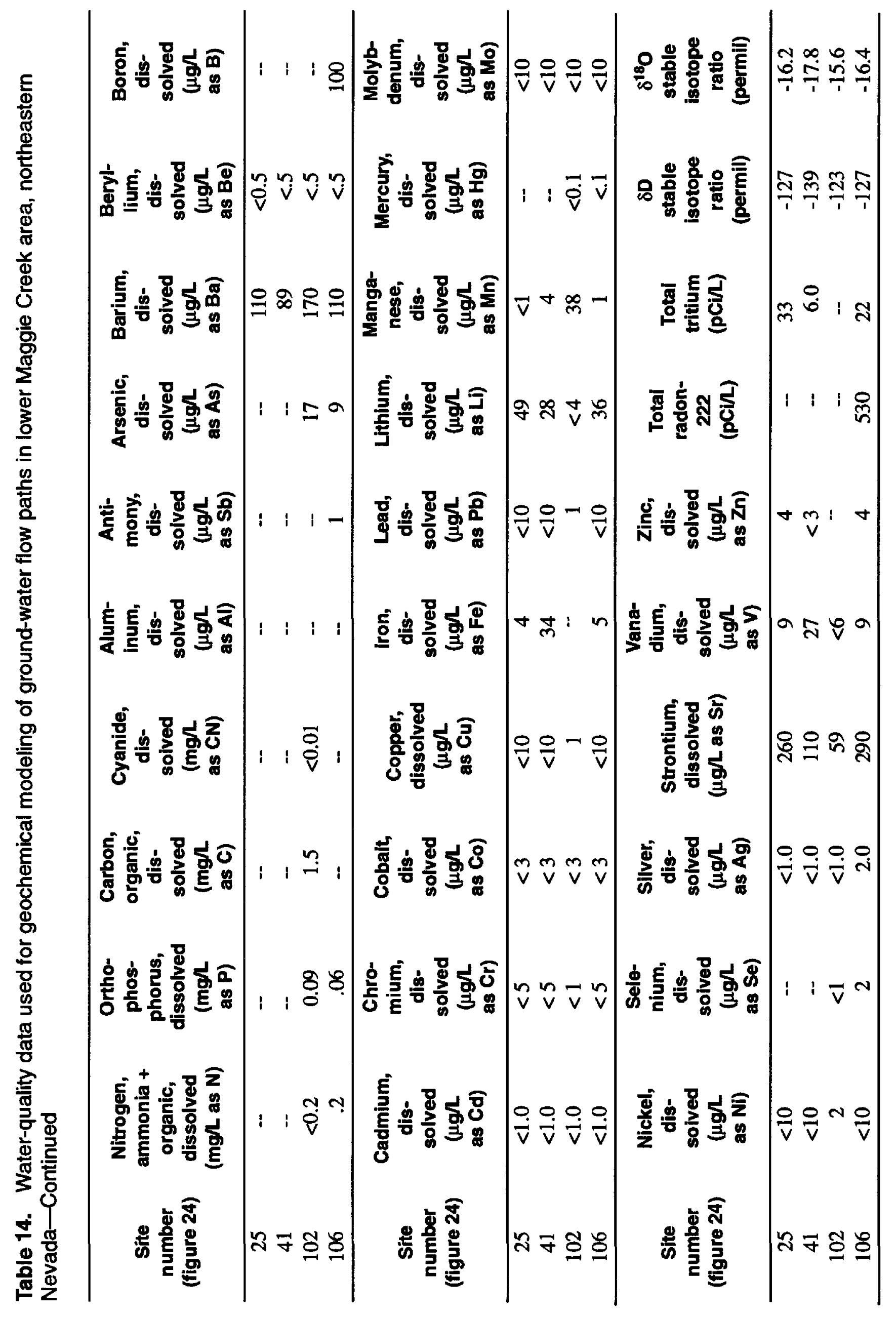

